\title{
Nitrate exposure and endogenous formation of carcinogenic nitrosamines in humans
}

Citation for published version (APA):

Vermeer, I. T. M. (2000). Nitrate exposure and endogenous formation of carcinogenic nitrosamines in humans. [Doctoral Thesis, Maastricht University]. UM. https://doi.org/10.26481/dis.20001130iv

Document status and date:

Published: 01/01/2000

DOI:

10.26481/dis.20001130iv

Document Version:

Publisher's PDF, also known as Version of record

\section{Please check the document version of this publication:}

- A submitted manuscript is the version of the article upon submission and before peer-review. There can be important differences between the submitted version and the official published version of record.

People interested in the research are advised to contact the author for the final version of the publication, or visit the DOI to the publisher's website.

- The final author version and the galley proof are versions of the publication after peer review.

- The final published version features the final layout of the paper including the volume, issue and page numbers.

Link to publication

\footnotetext{
General rights rights.

- You may freely distribute the URL identifying the publication in the public portal. please follow below link for the End User Agreement:

www.umlib.nl/taverne-license

Take down policy

If you believe that this document breaches copyright please contact us at:

repository@maastrichtuniversity.nl

providing details and we will investigate your claim.
}

Copyright and moral rights for the publications made accessible in the public portal are retained by the authors and/or other copyright owners and it is a condition of accessing publications that users recognise and abide by the legal requirements associated with these

- Users may download and print one copy of any publication from the public portal for the purpose of private study or research.

- You may not further distribute the material or use it for any profit-making activity or commercial gain

If the publication is distributed under the terms of Article $25 \mathrm{fa}$ of the Dutch Copyright Act, indicated by the "Taverne" license above, 
Nitrate exposure and endogenous formation of carcinogenic nitrosamines in humans

I.T.M. Vermeer 
(C) 2000 I.T.M. Vermeer

ISBN: 90-9014224-X

Omslagillustratie: Ingrid Vermeer en Grafisch Service Centrum Van Gils BV.

Druk: Grafisch Service Centrum Van Gils BV, Wageningen.

fiffin The studies presented in this thesis were performed at the IUCIII Nutrition and Toxicology Research Institute Maastricht (NUTRIM) which participates in the Graduate School VLAG (Food Technology, Agrobiotechnology, Nutrition and Health Sciences), accredited by the Royal Netherlands Academy of Arts and Sciences. 


\section{Nitrate exposure and endogenous formation of carcinogenic nitrosamines in humans}

\section{PROEFSCHRIFT}

ter verkrijging van de graad van doctor aan de Universiteit Maastricht,

op gezag van de Rector Magnificus, Prof. Dr. A.C. Nieuwenhuijzen Kruseman, volgens het besluit van het College van Decanen, in het openbaar te verdedigen op donderdag 30 november 2000 om 16.00 uur

door

Ingrid Theodora Maria Vermeer

geboren te Eindhoven op 29 november 1971 


\section{Promotor:}

Prof. dr. J.C.S. Kleinjans

\section{Co-Promotores:}

Dr. J.M.S. van Maanen

Dr. L.G.J.B. Engels

\section{Beoordelingscommissie:}

Prof. dr. P. Soeters (voorzitter)

Prof. dr. A. Bast

Prof. dr. J. Koeman (Wageningen Universiteit)

Prof. dr. R. Kroes (Universiteit Utrecht)

Prof. dr. R. Stockbrügger 
Voor mijn ouders,

Marja en Theo, John-Paul. 


\section{Contents}

Abbreviations

Chapter 1 General introduction 9

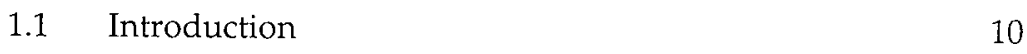

1.2 Nitrate and nitrite exposure 11

1.2.1 Endogenous nitrate synthesis 12

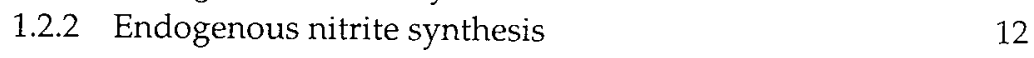

1.2.3 Nitrate and nitrite clearance 13

1.3 Adverse health effects of exposure to nitrate and nitrite 13

1.3.1 Standards for nitrate and nitrite: drinking water 14 guideline and ADI values

1.4 NOC and carcinogenicity $\quad 15$

1.5 Metabolism and DNA adduct formation 16

1.6 Human exposure to NOC 18

1.6.1 Exogenous exposure to NOC 18

$\begin{array}{ll}1.6 .2 & \text { Endogenous exposure to NOC } \\ 1.79\end{array}$

1.7 High risk groups 20

1.8 Inhibition of endogenous NOC formation 21

1.9 Aim and outline of this thesis $\quad 21$

Chapter 2 Determination of N-nitrosodimethylamine in 29 artificial gastric juice by gas chromatography-mass spectrometry and by gas chromatography-thermal energy analysis

Chapter 3 Volatile $\mathrm{N}$-nitrosamine formation after intake of nitrate at the ADI level in combination with an amine-rich diet

Chapter 4 Effect of ascorbic acid and green tea on endogenous formation of N-nitrosodimethylamine and $\mathrm{N}$-nitrosopiperidine in humans 
Chapter 5 Intragastric volatile $\mathrm{N}$-nitrosamines, nitrite, and $\mathrm{pH}$

Chapter 6 Evidence for the lack of Helicobacter pylori-mediated formation of carcinogenic $\mathrm{N}$-nitrosamines

Chapter 7 Neutrophil-mediated formation of carcinogenic

$\mathrm{N}$-nitroso compounds in an in vitro model

for intestinal inflammation

Chapter 8 Summary and general discussion

Samenvatting

Dankwoord

Curriculum vitae 


\section{Abbreviations}

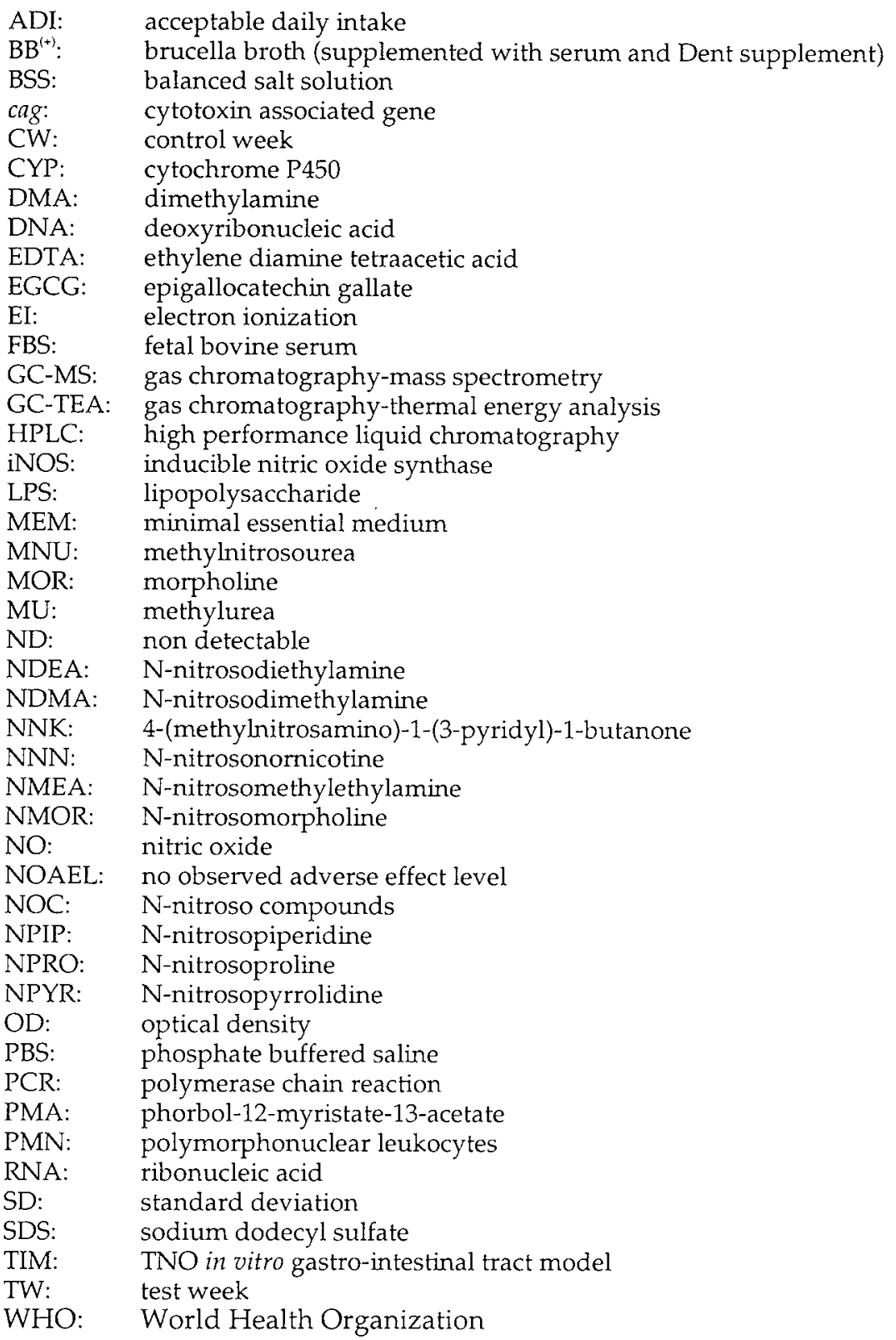


Chapter 1

General introduction 


\subsection{Introduction}

Humans are exposed to a wide variety of compounds. Some of these compounds, either from natural or synthetic origin, can be highly toxic to humans; others are (relatively) harmless. It has long been recognized that toxicity of compounds depends on the level of exposure. The Swiss doctor Paracelsus (1493-1541) made the famous statement: "Dosis sola facit venenum" (freely translated: every compound is toxic, only the dose defines whether a compound is not toxic), a quotation that is still valid today. To protect the health of the human population, it is necessary to study (possibly) toxic compounds and gain insight in exposure, absorption, distribution, and excretion of these compounds. Based on human exposure and consequent adverse effects, a risk-evaluation is performed and guidelines are set to prevent exposure of the human population to unsafe doses of a given compound. The acceptable daily intake (ADI) of noncarcinogenic compounds is often based on the no observed adverse effect level (NOAEL) in laboratory animals, divided by a safety factor of 100 (1). Risk-evaluation for carcinogens is more complicated. In theory, the smallest amount of a carcinogen is sufficient to cause cancer, and a safe dose cannot be set. Extrapolation models as the one-hit model are used for carcinogens.

At present, the existing guidelines for drinking water, and ADI's (acceptable daily intake values) for nitrate and nitrite are being discussed. Nitrate is widely distributed in the environment. The most important source of nitrate dispersion is agriculture, due to the extensive use of fertilizers (2). After ingestion, nitrate is partly converted into nitrite, which can oxidize hemoglobin to methemoglobin. After high nitrate (or nitrite) exposure, this may lead to methemoglobinemia (3-6). Guidelines for nitrate and nitrite in drinking water are based on prevention of the occurrence of methemoglobinemia; ADI values are based on the NOAEL determined in toxicity studies with rats. However, endogenous formation of carcinogenic N-nitroso compounds (NOC), which may occur after reaction of nitrite with amines or amides, was not taken into account in the assessment of the guidelines. More data on endogenous formation of NOC after exposure to nitrate at the level of the current ADI, and the resulting biological consequences of exposure to NOC, are needed. Moreover, this was also recommended by the WHO (World Health Organization) (2). Based on these data, a better validated decision on the drinking water guidelines for nitrate and nitrite and the acceptable daily intake values can be made. 


\subsection{Nitrate and nitrite exposure}

Humans are exposed to nitrate via ingestion of nitrate-containing food and drinking water. Nitrate content of public drinking water supplies is low; in most European countries, the public drinking water supplies contain less than $45 \mathrm{mg}$ nitrate per liter (2). However, nitrate levels, in particular in groundwater, have increased significantly during the last decades due to intensive animal farming and increased use of fertilizers (2). This can lead to high nitrate levels in groundwater, up to levels of $300 \mathrm{mg} / 1$ (7). In general, people use public drinking water supplies, e.g. containing levels up to $10 \mathrm{mg} / 1$ nitrate, and the predominant source of nitrate exposure, accounting for approximately $75-80 \%$ of the nitrate intake, are green leafy vegetables, e.g. lettuce, spinach, endive, beetroot, turnip, and celery, which contain relatively high nitrate levels (>1000 $\mathrm{mg} / \mathrm{kg}$, see Table 1) $(8,9)$.

Table 1. Average concentrations (in $\mathrm{mg} / \mathrm{kg}$ fresh weight) of nitrate and nitrite in vegetables and cured meat products.*

\begin{tabular}{lll}
\hline Vegetable/meat product & Nitrate & Nitrite \\
\hline Asparagus & 60 & 0.9 \\
Beet & 3288 & 6.0 \\
Brussels sprouts & 164 & 1.5 \\
Celery & 3151 & 0.8 \\
Endive & 1780 & 0.8 \\
Lettuce & 2330 & 0.6 \\
Leek & 700 & - \\
Peas & 40 & 0.9 \\
Potato & 150 & 0.9 \\
Radish & 2600 & 0.3 \\
Rhubarb & 2900 & - \\
Spinach & 2470 & 3.8 \\
Tomato & 80 & - \\
Turnip (greens) & 9040 & 3.5 \\
Bacon & & \\
Comed beef & 43 & 24 \\
Cured beef & 10 & 5 \\
Cured turkey & 29 & 11 \\
Ham & 19 & 54 \\
Luncheon meat & 22 & 26 \\
L & 21 & 24 \\
\hline
\end{tabular}

* Data taken from Walker and Gangolli et al. $(8,9)$. 
However, when drinking water with nitrate at the level of the current standard of $50 \mathrm{mg} / \mathrm{l}$ is consumed, for instance, in case of private water wells, the contribution of drinking water to the total nitrate intake can increase to $40-70 \%$ of the total nitrate intake. Nitrite content in vegetables is generally low, and rarely exceeds 2 $\mathrm{mg} / \mathrm{kg}(8,9)$. Nitrate and nitrite are also added to food components as preservatives to cure meat and meat products. Due to improved technology, nitrate and nitrite contents of cured meat have declined considerably between 1960 and 1980 (Table 1) (9).

\subsubsection{Endogenous nitrate synthesis}

Besides exposure to nitrate by food consumption, endogenous synthesis of nitrate also occurs. Studies with laboratory animals have shown that urinary nitrate excretion can exceed nitrate intake. Conventional and germ-free rats receiving a diet low in nitrate, excreted nitrate in excess to the intake. Nitrate synthesis was estimated at a rate of $1.24 \mathrm{mg} / \mathrm{kg}$ body weight/day (10). Endogenous nitrate synthesis in humans was reported to be of the same order of magnitude, about 1 $\mathrm{mg} / \mathrm{kg}$ body weight/day (11). Endogenous synthesis of nitrate occurs via conversion of arginine to citrulline by nitric oxide synthase, thereby generating nitric oxide (NO), followed by oxidation of $\mathrm{NO}$ to $\mathrm{N}_{2} \mathrm{O}_{3}$ and $\mathrm{N}_{2} \mathrm{O}_{4}$, and finally resulting in the production of nitrate and nitrite (12-14). Macrophages and polymorphonuclear neutrophils are responsible for the production of NO by nitric oxide synthase (15-17). Stimulation of these immune cells during inflammation, e.g. during colitis or bacterial infection, can locally create high nitrate concentrations which may result in high urinary nitrate excretion levels. During gastrointestinal infection, the endogenous nitrate synthesis can increase to levels of about $7-15 \mathrm{mg} / \mathrm{kg}$ body weight/day (8).

\subsubsection{Endogenous nitrite synthesis}

Possible adverse health effects of nitrate are mainly due to endogenous conversion of nitrate to nitrite. After ingestion, nitrate is readily absorbed from the upper small intestine (18). Blood nitrate is selectively transported and about $25 \%$ is secreted into the saliva by a carrier mediated transport system, in competition with iodide and thiocyanate $(19,20)$. In the oral cavity, about $20 \%$ of the salivary nitrate is reduced to nitrite by bacteria colonizing the saliva (19). Thus, about $5 \%$ of dietary nitrate is endogenously converted into nitrite in the oral cavity. Since bacteria with nitrate reducing activity are also present at other sites in the body, namely the distal small intestine, the colon, and the stomach (if the gastric $\mathrm{pH}$ is above 5), these bacteria will contribute to the endogenous nitrite synthesis, depending on the local nitrate availability. Furthermore, in small infants, up to 3 months of age, the conversion of nitrate to nitrite may be raised to $80 \%$, in particular due to the occurrence of gastrointestinal bacterial infection. 


\subsubsection{Nitrate and nitrite clearance}

Ingested nitrate is rapidly absorbed and peak salivary nitrate levels are reached after 1-3 hours, depending on the nitrate source (as vegetable juice or as vegetable, respectively) (19). Approximately $65-70 \%$ of the ingested nitrate is excreted via urine within 24 hours, independently of the amount of nitrate ingestion, and less than $1 \%$ is excreted via faeces (18). The rest of the ingested nitrate is converted into nitrite, secreted via sweat, via colonic or vaginal secretions, and via tears $(18,21)$. Nitrite is not normally detectable in tissues and body fluids of animals following oral administration due to its rapid oxidation to nitrate. Nitrite is oxidized in blood by a coupled oxidation reaction with oxyhaemoglobin, producing methaemoglobin (8).

\subsection{Adverse health effects of exposure to nitrate and nitrite}

The major human health risk associated with nitrate exposure is considered to be methemoglobinemia (also called blue baby syndrome). Nitrate per se is relatively non-toxic. Chronic studies with laboratory animals showed that nitrate exposure did not increase tumor incidence and the reported no observed adverse effect level (NOAEL) used to establish the ADI value for nitrate, was $500 \mathrm{mg} \mathrm{NaNO} / \mathrm{kg}$ body weight/day (365 $\mathrm{mg} \mathrm{NO}$ ion/ $\mathrm{kg} /$ day). The NOAEL for nitrite originally used to establish the ADI value for nitrite, was $20 \mathrm{mg} \mathrm{NaNO}_{2} / \mathrm{kg}$ body weight/day (13.3 $\mathrm{mg} \mathrm{NO}$ ion $/ \mathrm{kg} /$ day). More recently, also a lower NOAEL value of $6 \mathrm{mg} \mathrm{NO}$ ion $/ \mathrm{kg}$ body weight/ day was reported and used to calculate a new ADI value for nitrite (22). Nitrite is not carcinogenic in laboratory animals, but is acutely toxic, since nitrite is a powerful oxidizing agent, capable of converting hemoglobin into methemoglobin. Methemoglobin is unable to carry oxygen, which results in cyanosis as the level of methemoglobin reaches $10 \%$ of the total hemoglobin, and leads to death at levels of $60 \%$ (23).

Young infants are more susceptible to methemoglobinemia than older children and adults, mainly because they lack the enzyme methemoglobin reductase, which becomes active after weaning, and because the foetal hemoglobin is more sensitive to oxidation than adult hemoglobin (24). The association between nitrate-rich water, used to prepare baby food, and methemoglobinemia has been described in 1945 (3). Recently however, this straight-forward conclusion has been criticized $(24,25)$. It appeared that nitraterich well water was frequently contaminated with bacteria, resulting in relatively high nitrite levels in the water. Furthermore, it was established that gastrointestinal infection and inflammation (and not high nitrate intake), are important causes of endogenous NO and nitrite production, resulting in methemoglobinemia (24-26). 
Another important risk of nitrate exposure is the endogenous formation of carcinogenic $\mathrm{N}$-nitroso compounds (NOC). Nitrite derived from nitrate, may react with amines and amides, a reaction that predominantly occurs in the acidic stomach, resulting in the formation of carcinogenic NOC. Exposure to endogenously formed NOC has been associated with gastric, esophageal and bladder cancer (27). Since 1976, at least 8 different human epidemiology studies conducted in 11 countries have shown a relationship between increasing rates of stomach cancer and increasing nitrate intake $(28,29)$. Several of these studies describe a relationship between intake of nitrate in drinking water and gastric cancer $(30,31)$. Ward et al. (32) found an association between consumption of nitrate-containing drinking water (>17.8 mg nitrate/l) and the risk of nonHodgkin's lymphoma. Nitrate exposure has also been related to increased hprt variant frequencies in lymphocyte DNA of humans using private well water (33).

Other adverse health effects of nitrate exposure have also been described. Nitrate exposure can lead to hypertrophy of the thyroid (7). Nitrite exposure may result in hypertrophy of the adrenal zona glomerulosa (34). Furthermore, increased levels of nitrate in drinking water have been associated with childhood insulin-dependent diabetes mellitus $(35,36)$.

\subsubsection{Standards for nitrate and nitrite: drinking water guideline and ADI values.}

The World Health Organization (WHO) has set guidelines to protect humans against the adverse effects of exposure to nitrate and nitrite. However, concerning the guidelines for nitrate and nitrite, several points are of interest:

- The current drinking water guidelines are set to prevent the occurrence of methemoglobinemia, and the endogenous formation of carcinogenic NOC has not been taken into account (22).

- The acceptable daily intake (ADI) is based on the NOAEL observed in rat studies, applying a safety factor of 100 . However, rats do not actively secrete nitrate via the salivary glands, thus no ingested nitrate is converted into nitrite by bacterial activity in the oral cavity (9), and the ADI value of nitrate is not based on the nitrate-nitrite conversion as occurring in humans.

- The ADI for nitrate and nitrite is, respectively, $3.65 \mathrm{mg} / \mathrm{kg}$ body weight/day and $0.06 \mathrm{mg} / \mathrm{kg}$ body weight/day (expressed as nitrate and nitrite ion) (22). For a person of $60 \mathrm{~kg}$ the ADI for nitrate is $220 \mathrm{mg} /$ day. Assuming that $5 \%$ of the ingested nitrate is converted to nitrite, this implies a nitrite exposure of 11 $\mathrm{mg} /$ day. The ADI for nitrite, however, is $3.6 \mathrm{mg} /$ day for a person of $60 \mathrm{~kg}$. Thus, due to the conversion of nitrate into nitrite, the ADI of nitrite is already exceeded during nitrate intake at the ADI level of nitrate.

The WHO guideline for nitrate in drinking water indicates a maximally admissible concentration of $50 \mathrm{mg} \mathrm{NO}_{3}^{*} / 1$ (37). In Europe, this guideline is set by 
the European Community at $50 \mathrm{mg} / \mathrm{l}$, with a target concentration of $25 \mathrm{mg} / \mathrm{l}(38)$. In the Netherlands, the drinking water guideline for nitrite is $0.1 \mathrm{mg} / 1(38,39)$. Furthermore, guidelines are set for maximally admissible nitrate and nitrite concentrations in food. In the Netherlands, maximally admissible nitrate and nitrite concentrations in cured meat products are 304 and $133 \mathrm{mg} / \mathrm{kg}$, respectively (40). Maximally admissible nitrate concentrations in vegetables vary from 3500 $\mathrm{mg} / \mathrm{kg}$ fresh weight (from April 1-November 1) to $4500 \mathrm{mg} / \mathrm{kg}$ fresh weight (November 1-April 1).

\subsection{NOC and carcinogenicity}

$\mathrm{N}$-nitroso compounds are characterized by a nitroso group $(-\mathrm{N}=\mathrm{O})$ bound to a nitrogen atom. NOC are a class of chemicals composed of nitrosamines and nitrosamides. Fig. 1 shows the general formulas and some examples. Most nitrosamines are volatile, and nitrosamides are thermally unstable (27).

The carcinogenicity of NOC has been studied extensively in laboratory animals. $85 \%$ of the 209 tested nitrosamines and $92 \%$ of the tested nitrosamides were carcinogenic in 39 animal species, including species of fish, frogs, hamsters, mice, rats, and monkeys (41). The carcinogenicity of nitrosamines appears to be organspecific and in rodents nitrosamines induce tumors mainly in the liver, esophagus, nasal and oral mucosa, lung, urinary bladder, kidney, pancreas and thyroid, independently of the route of administration $(27,42)$. Nitrosamides principally cause tumors at the site of administration, e.g. when given orally, tumors are induced in the glandular stomach.

Nitrosamines: $\mathrm{R}_{1} \mathrm{NNOR}_{2}$<smiles>CN(C)N=O</smiles>

$\mathrm{N}$-nitrosodimethylamine (NDMA)<smiles>O=NN1CCOCC1</smiles>

$\mathrm{N}$-nitrosomorpholine (NMOR)
Nitrosamides: $\mathrm{R}_{1}$ NNO.COR<smiles>CN(N=O)C(N)=O</smiles>

Methylnitrosourea (MNU)

Figure 1. General formulas of nitrosamines and nitrosamides and the structures of several NOC. 
In humans, exposure to NOC has been related to an increased risk of gastric, esophageal, nasopharyngeal, bladder, and colorectal cancer (27,43-45). Using the NPRO (N-nitrosoproline) test as indicator of endogenous formation of NOC, higher exposures to endogenously formed NOC were found in subjects at high risk for gastric, esophageal, oral cavity, and bladder cancer (46-50). Although results from epidemiological studies point to a role of NOC in the etiology of human cancer, causality has not been established. However, since NOC are carcinogenic in 39 animal species, it is not likely that humans will be an exception. Furthermore, several cases of N-nitrosodimethylamine poisoning demonstrated that the symptoms of acute toxicity of NDMA in humans (predominantly liver damage) were comparable with those observed in experimental animals (51-53).

\subsection{Metabolism and DNA adduct formation}

Nitrosamines require enzymatic activation to form reactive intermediates, which can bind to DNA. The general reaction scheme is shown in Fig. 2 (54-56).

Metabolism of nitrosamines starts with $\alpha$-hydroxylation by cytochrome P450 enzymes (Fig. 2, path a). Detoxification by denitrosation is competing with this activation process (see Fig. 2, path b) (57). $\alpha$-hydroxynitrosamines spontaneously decompose to yield, successively, monoalkyl-nitrosamines, alkyldiazohydroxides and alkyldiazonium ions. Simple nitrosodialkylamines such as NDMA are activated by CYP 2E1; other, more complex nitrosamines are activated by other cytochrome P450 enzymes such as CYP 2A6, 2C8, 2C9, 2C19 and 3A4 (58). Nitrosamides do not require metabolic activation. Instead, nitrosamides spontaneously hydrolyze to monoalkylnitrosamines (Fig. 2, path c), and subsequently follow the same pathway as nitrosamines (56).

Alkyldiazonium ions can be detoxified by water to the corresponding alcohol (Fig. 2, path d). A very small fraction of the generated alkyldiazonium ions may react with DNA, RNA and proteins. This was illustrated by a study with isolated rat hepatocytes: one O6-methyldeoxyguanosine adduct was formed per 133.000 metabolized NDMA molecules (59). The alkyldiazonium ions can alkylate DNA at the N-3, N-7 and O-6 positions of guanine, the N-1, N-3 and N-7 positions of adenine, the N-3 and $\mathrm{O}-2$ positions of cytosine and the N-3, O-4 and O-2 positions of thymine and at the $\mathrm{O}$-atoms of phosphate internucleotide linkages (60). 
Nitrosamine:

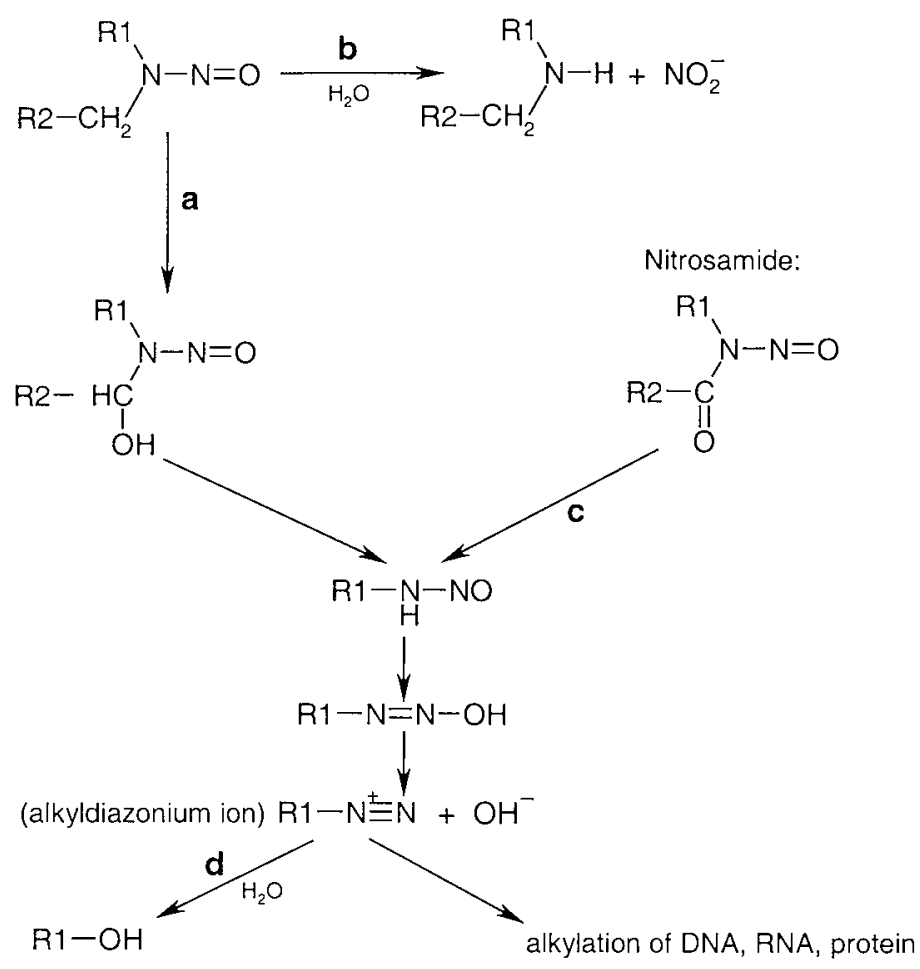

Figure 2. Reaction scheme of NOC metabolism. a: $\alpha$-hydroxylation by cytochrome P450. $\mathbf{b}$ : detoxification by denitrosation of nitrosamines. c: spontaneous hydrolysis. d: detoxification reaction with $\mathrm{H}_{2} \mathrm{O}$ to corresponding alcohol.

Quantitatively, the major DNA adducts generated by alkylating NOC, are N7-alkylguanines, and, in smaller amounts, O6-alkylguanines (61,62). N7alkylguanine is not a premutagenic adduct; however, O6-alkylguanines pair with thymine rather than cytosine, producing $\mathrm{G}: \mathrm{C} \rightarrow \mathrm{A}: \mathrm{T}$ mutations that are involved in initiation of carcinogenesis. The alkylation site (N7 or O6) depends on the type of alkylating agent and is reflected in the O6:N7-alkylguanine ratio (60). NOC with a relatively high 06:N7 ratio (e.g. NDMA and MNU) are strong mutagens and carcinogens. NOC with a relatively low $\mathrm{O} 6 \mathrm{~N}$ / 7 ratio are characterized by weak mutagenic and carcinogenic activity (62).

O6- and N7-alkylguanine may be used as markers of exposure to alkylating NOC. Since O6-alkylguanine is the premutagenic lesion, this would be the most valuable marker. However, the alkyl group from O6-alkylguanine is efficiently 
removed by O6-alkylguanine-DNA-alkyltransferase, so the level of O6alkylguanine in tissue DNA is a function of formation and repair $(61,62)$. Since N7-alkylguanine is more stable and present at much higher levels (10-100 times), this may be a more useful marker of exposure. Both markers have already been applied to study human exposure to $\operatorname{NOC}(53,63)$.

\subsection{Human exposure to NOC}

Humans are exposed to preformed NOC (exogenous exposure) and NOC formed after ingestion of nitrate and nitrite (endogenous exposure).

\subsubsection{Exogenous exposure to NOC}

Several excellent reviews about exogenous exposure to NOC have been published $(55,64-67)$. The most relevant sources of exposure will be summarized here. There are predominantly three sources of exposure to preformed NOC:

- Occupational exposure. Workers in the rubber, leather and metal industries are exposed to high levels of nitrosamines, predominantly NDMA, Nnitrosodiethylamine (NDEA), and NMOR. Working in the rubber industry has been associated with bladder, gastric, and lung cancer and leukemia (68). Due to new regulations, exposure levels in these industries have markedly decreased. For example, regulations in Germany allow levels $<2.5 \mu \mathrm{g} / \mathrm{m}^{3}$ (compared with levels up to $380 \mu \mathrm{g} / \mathrm{m}^{3}$ in the earlier days).

- Tobacco. Human non-occupational exogenous exposure to NOC is most extensive in tobacco users. Tobacco contains relatively high levels of the tobacco specific nitrosamines NNN (N-nitrosonomicotine) and NNK (4(methylnitrosamino)-1-(3-pyridyl)-1-butanone), which may contribute to the induction of lung, esophageal, pancreas, nasal and oral mucosa cancer caused by tobacco (27). Tricker (65) estimated the tobacco-related exposure to NOC. Smoking 20 cigarettes/day results in an NOC exposure of $3.4 \mu \mathrm{g} /$ day, and users of nasal snuff tobacco are exposed to $27.5 \mu \mathrm{g} /$ day. Bartsch and Spiegelhalder (64) reported higher estimates: up to $48 \mu \mathrm{g} /$ day for heavy smokers, and up to $700 \mu \mathrm{g} /$ day for snuff users.

- Diet. Nitrosamine levels in cured meat products used to be relatively high during the 1980's (up to $100 \mathrm{ppb}$ ), but due to improved technology nitrosamine concentrations (mainly NDMA and NPYR (N-nitrosopyrrolidine)) in cured meat products are now generally $<10 \mathrm{ppb}$ (55). Other food products, e.g. beer, cheese and fish, contain lower amounts of nitrosamines. The estimated daily intake in most industrialized countries is about $1 \mu \mathrm{g} /$ person. 


\subsubsection{Endogenous exposure to NOC}

The acidic stomach is considered to be the major site of endogenous nitrosation in humans. Under acidic conditions, nitrite will form nitrous acid $\left(\mathrm{HNO}_{2}\right)$. Two molecules of $\mathrm{HNO}_{2}$ are converted into water and $\mathrm{N}_{2} \mathrm{O}_{3}$, which reacts with amines to nitrosamines. $\mathrm{HNO}_{2}$ can also be protonated to $\mathrm{H}_{2} \mathrm{NO}_{2}{ }^{+}$, which reacts with amides to nitrosamides $(13,27)$.

At neutral $\mathrm{pH}$, bacteria can catalyze the nitrosation reaction. This can take place in the achlorhydric stomach, when bacteria are able to colonize the stomach, and at other sites of the body such as the duodenum, intestine and colon. Bacteria with the capacity to catalyze the nitrosation reaction are mainly bacteria with nitrate-reducing activity (denitrifying bacteria). Nitrite is reduced to $\mathrm{NO}$ by bacteria, and, subsequently, $\mathrm{NO}$ reacts with dissolved oxygen to $\mathrm{N}_{2} \mathrm{O}_{3}$ and $\mathrm{N}_{2} \mathrm{O}_{4}$, which can nitrosate amines $(13,27,55)$.

The last mechanism of endogenous nitrosation relates to inflammation. Activated macrophages and, to a lesser extent, polymorphonuclear neutrophils, produce $\mathrm{NO}$ in response to immune stimulation. L-arginine is converted into Lcitrulline by inducible nitric oxide synthase (iNOS), thereby liberating NO (69). Again, $\mathrm{NO}$ reacts with oxygen to $\mathrm{N}_{2} \mathrm{O}_{3}$ and $\mathrm{N}_{2} \mathrm{O}_{4}$, which are potent nitrosating agents. The different mechanisms of endogenous nitrosation are summarized in Figure 3.

Tricker (65) roughly estimated that about $40-75 \%$ of the total human exposure to NOC results from endogenous formation.

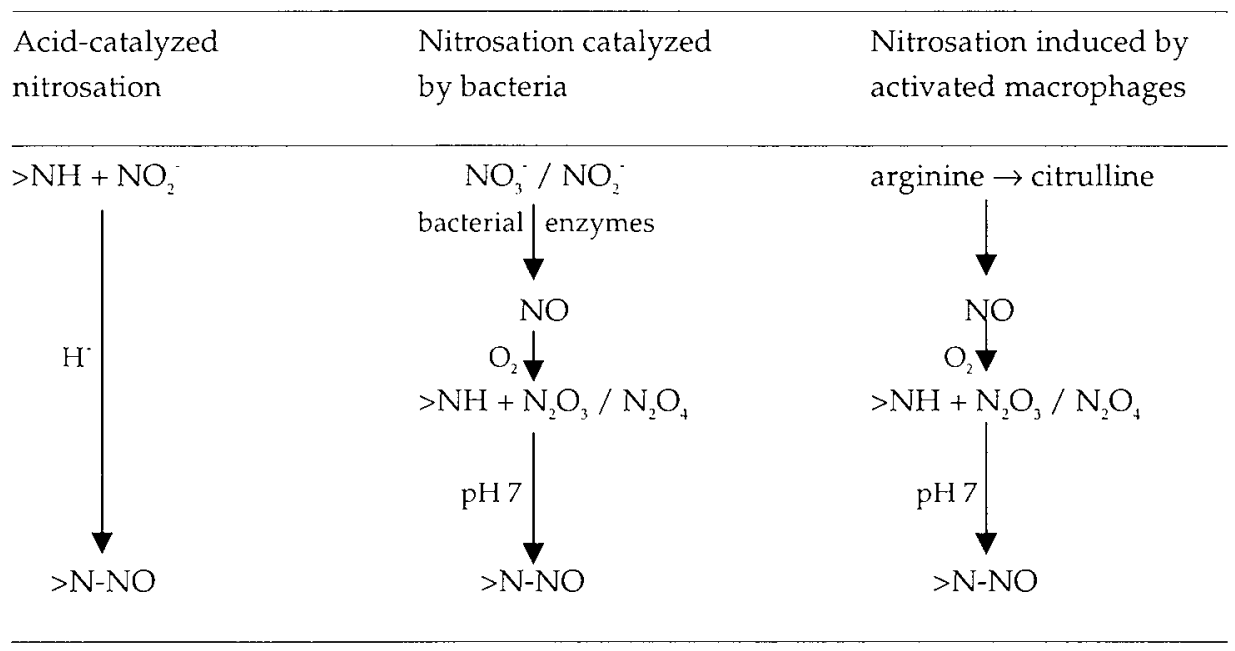

Figure 3. Mechanisms of endogenous nitrosation (Modified from Bartsch and Spiegelhalder) (64). 


\subsection{High risk groups}

Subgroups of the population can be identified as high risk groups for nitrate-, nitrite- or NOC exposure for two reasons:

A. Because of high risk of exposure to nitrate, nitrite or NOC.

- People using private well water with high nitrate levels, or public water supplies with high nitrate levels.

- People consuming relatively high amounts of green leafy vegetables, e.g. vegetarians, and people who culture their own vegetables.

- Workers in certain industries (e.g. rubber industry), and smokers are exposed to nitrosamines.

- People consuming high amounts of NOC via food intake.

- Kidney patients may have increased conversion of nitrate to nitrite due to more frequent recirculation of nitrate before excretion.

- People with bacterial infections, achlorhydric stomach, or inflammatory diseases are at high risk of endogenous synthesis of nitrate, nitrite, and NOC.

- People with certain enzyme-deficiencies or decreased enzyme activity. For example, one of the main DNA adducts formed after exposure to methylating nitrosamines is O6-methylguanine, and this methyl group is removed from DNA by the enzyme O6-methylguanine-alkyltransferase (70). A large interindividual variation has been observed in the activity of O6-methylguanine-alkyltransferase due to genetic polymorphisms of the gene $(71,72)$. The enzyme methemoglobin reductase converts methemoglobin into hemoglobin. This enzyme is not mature in infants and is less active in people with a deficiency of glucose-6-phosphate dehydrogenase (23).

B. Because of high risk of effects by nitrate, nitrite or NOC.

- Infants are more sensitive to nitrite, and to methemoglobinemia, in particular bottle-fed infants up to 3 months of age. Foetal hemoglobin is more readily oxidized than adult hemoglobin, and the enzyme methemoglobin reductase is not mature in infants.

- People with chronic oxygen deficiency are more sensitive to nitrite.

- Pregnant women are more sensitive to nitrite-induced methemoglobinemia. 


\subsection{Inhibition of endogenous NOC formation}

In vitro, a variety of compounds has been shown to inhibit the nitrosation reaction. These include vitamins (ascorbic acid and $\alpha$-tocopherol), phenolic compounds (e.g. catechol, phenolic acids, hydroquinones), complex mixtures (such as alcoholic beverages, milk products, tea), sulphur compounds (e.g. glutathione, methionine), and a group of miscellaneous compounds (urea, unsaturated fatty acids, caffeine and others), reviewed by Bartsch et al. (73). In general, these compounds inhibit nitrosation by reduction of nitrite to NO, which is not directly a nitrosating agent. A few compounds reduce nitrous acid to $\mathrm{N}_{2}$ and $\mathrm{N}_{2} \mathrm{O}$, for example sulfamic acid, urea and hydrazine (73).

Inhibition of endogenous nitrosation has also been studied in humans. In most studies, the NPRO test was used. In a typical experiment, $500 \mathrm{mg}$ L-proline and $325 \mathrm{mg}$ nitrate were ingested and the amount of NPRO in 24-h urine was measured. The difference between the amount of NPRO excreted in urine and the amount ingested via food, is an indicator of endogenous NPRO formation, a noncarcinogenic and nonmetabolized NOC (74). Several compounds appeared very effective inhibitors of endogenous nitrosation: $1 \mathrm{~g}$ of ascorbic acid and 3-5 $\mathrm{g}$ of green tea completely inhibited the increase in urinary NPRO excretion $(75,76)$. However, this inhibition does not affect the 'basal' NPRO excretion (the excretion of NPRO without intake of nitrate and proline), suggesting that formation of NPRO has occurred at other sites than the stomach, which are not accessible to the nitrosation inhibitors $(77,78)$. Other compounds have been reported to partially inhibit nitrosation, for example $\alpha$-tocopherol, polyphenols, garlic, caffeic acid and betel-nut extracts, reviewed by De Kok and Van Maanen (79). Furthermore, the use of mouthwash solution with chlorhexidine was shown to inhibit formation of nitrosamines (80).

\subsection{Aim and outline of this thesis}

As explained in paragraph 1.3, the current drinking water guidelines and acceptable daily intake values for nitrate and nitrite do not take into account the endogenous formation of carcinogenic N-nitroso compounds. Quantitative data on endogenous formation of carcinogenic NOC are lacking. Guidelines are set for the general population; however, high risk groups can be identified and have to be studied separately. The most important site for endogenous formation of NOC is the stomach, but some mechanistic aspects of NOC formation in the stomach are still unknown, for instance the possible role of Helicobacter pylori, an important risk factor for stomach carcinogenesis. It is also important to assess whether possible NOC formation at other sites in the body can also contribute to the 
overall endogenous exposure to these carcinogenic compounds. The aim of the present thesis is to provide more information on endogenous formation of carcinogenic nitrosamines, and its genotoxic consequences, as a function of nitrate exposure, in man.

Therefore, the research topics of the present thesis are:

- To study whether formation of carcinogenic nitrosamines occurs in healthy volunteers, after a nitrate intake at the ADI level in combination with an amine-rich diet.

- To investigate whether endogenous formation of carcinogenic nitrosamines in healthy volunteers can be inhibited by food constituents like ascorbic acid and green tea.

- To study nitrosation and DNA adduct formation in a possible high risk group: patients on chronic treatment with omeprazole, and compare this patient group with control subjects.

- To study the possible role of Helicobacter pylori in formation of carcinogenic nitrosamines in the stomach (in vitro).

- To study mechanistic aspects of nitrosamine formation and biological consequences in the colon (in vitro study applying a coincubation system).

Chapter 2: The method applied in the present thesis to analyze volatile nitrosamines was gas chromatography-mass spectrometry (GC-MS). This method is compared with gas chromatography-thermal energy analysis (GC-TEA), which is widely applied for the detection of nitrosamines.

Chapter 3: Endogenous formation of nitrosamines was investigated after nitrate exposure via drinking water at the ADI level in combination with fish (which contains relatively high amounts of nitrosatable precursors), in a study with human volunteers.

Chapter 4: This chapter describes the effect of ascorbic acid and green tea on the formation of N-nitrosodimethylamine (NDMA) and N-nitrosopiperidine (NPIP) in human volunteers. Therefore, the protocol used in Chapter 3 was repeated, and in addition, different doses of ascorbic acid and green tea were given to the volunteers.

Chapter 5: Patients on long-term treatment with omeprazole were studied as possible high risk group for endogenous nitrosation. During gastroscopy, gastric juice and gastric biopsies were sampled. Furthermore, the patients collected a urine sample. Several parameters were determined, including nitrosamine levels and DNA adduct levels, and compared with levels in control subjects.

Chapter 6: Helicobacter pylori infection is associated with increased risk of gastric cancer, and has previously been shown to induce nitrosation of particular drugs 
in vitro. The nitrosating capacity of various $H$. pylori strains was studied as a possible explanation for the increased cancer risk.

Chapter 7: Neutrophil-mediated formation of carcinogenic NOC was studied in an in vitro model for intestinal inflammation, using Caco-2 cells as a model for colon epithelium.

Chapter 8: The studies described in this thesis are discussed and summarized.

\section{References}

1. Leeuwen, CJ van, Hermens JLM (ed.). Risk assessment of chemicals. An introduction. Kluwer Adacemic Publishers, Dordrecht. 1995.

2. World Health Organization. Health hazards from nitrates in drinking water. Environmental Health 1. WHO. Copenhagen. 1985.

3. Comly HH. Cyanosis in infants caused by nitrates in well water. JAMA 129: 112-116 (1945).

4. Walton B. Survey of the literature relating to infant methemoglobinemia due to nitrate contaminated water. Am J Public Health 41: 986-996 (1951).

5. Jaffé ER. Methaemoglobinaemia. Clin Haematol 10: 99-122 (1981).

6. Klaassen CD, Amdur MO, Doull J. Casarett and Doull's toxicology. The basic science of poison. MacMillan Publishing Company, New York (1986).

7. Maanen JMS van, Dijk A van, Mulder K, Baets MH de, Menheere PCA, Heide D van der, Mertens PLJM, Kleinjans JCS. Consumption of drinking water with high nitrate levels causes hypertrophy of the thyroid. Toxicol Lett 72: 365-374 (1994).

8. Gangolli SD, Brandt PA van den, Feron VJ, Janzowsky C, Koeman JH, Speijers GJA, Spiegelhalder G, Walker R, Wishnok JS. Nitrate, nitrite and N-nitroso compounds. Eur J Pharmacol 292: 1-38 (1994).

9. Walker R. Nitrates, nitrites and N-nitroso compounds: a review of the occurence in food and diet and the toxicological implications. Food Add Contam 5: 717-768 (1990).

10. Green LC, Tannenbaum SR, Goldman P. Nitrate synthesis in the germ-free and conventional rat. Science 212: 56-58 (1981).

11. Lee K, Greger JL, Consaul JR, Graham KL, Chinn BL. Nitrate, nitrite balance and de novo synthesis of nitrate in humans consuming cured meats. Am J Clin Nutr 44: 188194 (1986).

12. Leaf CD, Wishnok JS, Tannenbaum SR. L-arginine is a precursor for nitrate biosynthesis in humans. Biochem Biophys Res Commun 163: 1032-1037 (1989).

13. Leaf CD, Wishnok JS, Tannenbaum SR. Mechanisms of endogenous nitrosation. Cancer Surv 8: 323-334 (1989).

14. Gaston B, Drazen JM, Loscalzo J, Stamler JS. The biology of nitrogen oxides in the airways. Am J Respir Crit Care Med 149: 538-551 (1994).

15. Iyengar R, Stuehr DJ, Marletta MA. Macrophage synthesis of nitrite, nitrate, and Nnitrosamines: precursors and role of the respiratory burst. Proc Natl Acad Sci 84: 6369-6373 (1987).

16. Keller R, Keist R, Erb P, Aebischer T, De Libero G, Balzer M, Groscurth P, Keller HU. Expression of cellular effector functions and production of reactive nitrogen 
intermediates: a comparative study including I lymphocytes, T-like cells, neutrophil granulocytes, and mononuclear phagocytes. Cell Immunol 131: 398-403 (1990).

17. Wright CD, Mülsch A, Busse R, Osswald H. Generation of nitric oxide by human neutrophils. Biochem Biophys Res Commun 160: 813-819 (1989).

18. Bartholomew B, Hill MJ. The pharmacology of dietary nitrate and the origin of urinary nitrate. Fd Chem Toxic 22: 789-795 (1984).

19. Spiegelhalder B, Eisenbrand G, Preussmann R. Influence of dietary nitrate on nitrite content of human saliva: possible relevance to in vivo formation of $\mathrm{N}$-nitroso compounds. Food Cosmet Toxicol 14: 545-548 (1976).

20. Forman D, Al Dabbagh S, Doll R. Nitrates, nitrites and gastric cancer in Great Britain. Nature 313: 620-625 (1985).

21. Leach SA, Packer PJ, Hill MJ. Salivary and urinary nitrate as measures of nitrate intake. Biochem Soc Trans 15: 911-912 (1987).

22. WHO. Toxicological evaluation of certain food additives and contaminants. Prepared by the Forty-Fourth Meeting of the Joint FAO/WHO Expert Committee on Food Additives (JECFA). Geneva, World Health Organization, International Programme on Chemical Safety (WHO Food Additives Series 35) (1996).

23. Bruning-Fann CS, Kaneene JB. The effects of nitrate, nitrite and N-nitroso compounds on human health: a review. Vet Human Toxicol 35: 521-538 (1993).

24. McKnight GM, Duncan CW, Leifert C, Golden MH. Dietary nitrate in man: friend or foe? Br J Nutr 81: 349-358 (1999).

25. Avery AA. Infantile methemoglobinemia: reexamining the role of drinking water nitrates. Environ Health Perspect 107: 583-586 (1999).

26. Hegesh $\mathrm{E}$, Shiloah J. Blood nitrates and infantile methemoglobinemia. Clin Chim Acta 125: 107-115 (1982).

27. Mirvish SS. Role of N-nitroso compounds (NOC) and N-nitrosation in etiology of gastric, esophageal, nasopharyngeal and bladder cancer and contribution to cancer of known exposures to NOC. Cancer Lett 93: 17-48 (1995).

28. Hartmann PE. Putative mutagens/carcinogens in foods. I Nitrate/nitrite ingestion and gastric cancer mortality. Environ Mutagen 5: 111-121 (1983).

29. Mirvish SS. The etiology of gastric cancer: Intragastric nitrosamid formation and other theories. I Natl Cancer Inst 71: 631-647 (1983).

30. Gilli G, Corrao G, Favilli S. Concentrations of nitrate in drinking water and incidence of gastric carcinomas: First descriptive study of the Piemonte region, Italy. Sci Total Environ 24: 35-48 (1984).

31. Xu G, Song P, Reed PI. The relationship between gastric mucosal changes and nitrate intake via drinking water in a high risk population for gastric cancer in Moping county, China. Eur J Cancer Prev 1: 437-443 (1992).

32. Ward MH, Mark SD, Cantor KP, Weisenburger DD, Correa-Villaseñor A, Hoar Zahm S. Drinking water nitrate and the risk of non-Hodgkin's lymphoma. Epidemiology 7: 465-471 (1996).

33. Van Maanen JMS, Welle IJ, Hageman G, Dallinga JW, Mertens PLJM, Kleinjans JCS. Nitrate contamination of drinking water: relationship with hprt variant frequency in lymphocyte DNA and urinary excretion of N-nitrosamines. Environ Health Perspect 104: $522-529$ (1996). 
34. Til HP, Falke HE, Kuper CF, Willems MI. Evaluation of the oral toxicity of potassium nitrite in a 13-week drinking-water study in rats. Food Chem Toxicol 26: 851-859 (1988).

35. Parslow RC, McKinney PA, Law GR, Staines A, Williams R, Bodansky HJ. Incidence of childhood diabetes mellitus in Yorkshire, northern England, is associated with nitrate in drinking water: an ecological analysis. Diabetologia 40: 550-556 (1997).

36. Van Maanen JMS, Albering HJ, de Kok TMCM, van Breda SGJ, Curfs DMJ, Vermeer ITM, Ambergen AW, Wolffenbuttel BHR, Kleinjans JCS, Reeser HM. Does the risk of childhood diabetes mellitus require revision of the guideline values for nitrate in drinking water? Environ Health Perspect 108: 457-461 (2000).

37. WHO. Guidelines for drinking water quality. Vol. 2: Health criteria and other supporting information. $2^{\text {nd }}$ ed. Geneva: World Health Organization: 313-324 (1996).

38. EEC (European Economic Community). Council directive on the quality of water for human consumption, No. 80/778. Offic J EEC 229: 11-29 (1980).

39. Besluit van 2 april 1984, houdende wijziging van het Waterleidingbesluit (Stb. 1960, 345), 1984, Staatsblad Koninkrijk der Nederlanden 220, 's Gravenhage, Nederland.

40. Duijvenbooden W van, Matthijsen AJCM. Basisdocument nitraat. RIVM rapport No. 758473007: 4-5 (1987).

41. Bogovski P, Bogovski S. Animal species in which $\mathrm{N}$-nitroso compounds induce cancer. Int J Cancer 27: 471-474 (1981).

42. Lijinsky W, Kovatch RM. Carcinogenesis by nitrosamines and azoxyalkanes by different routes of administration to rats. Biomed Environ Sci 2: 154-159 (1989).

43. Hill MJ. Mechanisms of gastric carcinogenesis. Eur J Cancer Preo 2: 73-78 (1993).

44. Knekt P, Järvinen R, Dich J, Hakulinen T. Risk of colorectal and other gastrointestinal cancers after exposure to nitrate, nitrite and $\mathrm{N}$-nitroso compounds: a follow-up study. Int J Cancer 80: 852-856 (1999).

45. Magee PN. The experimental basis for the role of nitroso compounds in human cancer. Cancer Surv 8: 207-239 (1989).

46. Bartsch H, Oshima H, Pignatelli B, Calmels S. Human exposure to endogenous Nnitroso compounds: quantitative estimates in subjects at high risk for cancer of the oral cavity, oesophagus, stomach and urinary bladder. Cancer Surv 8: 335-362 (1989).

47. Bartsch H, Oshima H, Shuker DEG, Pignatelli B, Calmels S. Exposure of humans to endogenous N-nitroso compounds: implications in cancer etiology. Mutat Re's 238: 255-267 (1990).

48. Lu SH, Ohshima H, Fu HM, Tian Y, Li FM, Blettner M, Wahrendorf J, Bartsch H. Urinary excretion of $\mathrm{N}$-nitrosamino acids and nitrate by inhabitants of high- and low-risk areas for oesophageal cancer in Northern China: endogenous formation of nitrosoproline and its inhibition by vitamin C. Cancer Res 46: 1485-1491 (1986).

49. Stillwell WG, Glogowski J, Xu HX, Wishnok JS, Zavala D, Montes G, Correa P, Tannenbaum SR. Urinary excretion of nitrate, N-nitrosoproline, 3-methyladenine and 7-methylguanine in a Colombian population at high risk for stomach cancer. Cancer Res 51: 190-194 (1991).

50. Wu Y, Chen J, Ohshima H, Pignatelli B, Boreham J, Li J, Campbell TC, Peto R, Bartsch H. Geographic association between urinary excretion of N-nitroso compounds and oesophageal cancer mortality in China. Int J Cancer 54: 713-719 (1993). 
51. Pedal I, Besserer K, Goerttler K, Heymer B, Mittmeyer H-J, Oehmichen M, Schmäh] D. Fatal nitrosamine poisoning. Arch Toxicol 50: 101-112 (1982).

52. Fussgaenger RD, Ditschuneit $H$. Lethal exitus of a patient with Nnitrosodimethylamine poisoning, 2.5 years following the first ingestion and signs of intoxication. Oncology 37: 273-277 (1980).

53. Herron DC, Shank RC. Methylated purines in human liver DNA after probable dimethylnitrosamine poisoning. Cancer Res 40: 3116-3117 (1980).

54. Dipple A, Michejda CJ, Weisburger EK. Metabolism of chemical carcinogens. Pharmac Ther 27: 265-296 (1985).

55. Hecht SS. Approaches to cancer prevention based on an understanding of $\mathrm{N}$ nitrosamine carcinogenesis. Proc Soc Exp Biol Med 216: 181-191 (1997).

56. Shephard SE, Schlatter Ch, Lutz WK. Assessment of the risk of formation of carcinogenic N-nitroso compounds from dietary precursors in the stomach. Fd Chem Toxic 25: 91-108 (1987).

57. Streeter AJ, Nims RW, Sheffels PR, Heur Y-H, Yang CS, Mico BA, Gombar CT, Keefer LK. Metabolic denitrosation of N-nitrosodimethylamine in vivo in the rat. Cancer Res 50: 1144-1150 (1990).

58. Bellec G, Dréano Y, Lozach P, Ménez JF, Berthou F. Cytochrome P450 metabolic dealkylation of nine N-nitrosodialkylamines by human liver microsomes. Carcinogenesis 17: 2029-2034 (1996).

59. Encell L, Foiles PG, Gold B. The relationship between N-nitrosodimethylamine metabolism and DNA methylation in isolated rat hepatocytes. Carcinogenesis 17: 1127-1134 (1996).

60. Montesano R, Hall J. Nitrosamine metabolism and carcinogenesis. Environ Sci Res 31: 447-464 (1984).

61. Saffhill R, Margison GP, O'Connor PJ. Mechanisms of carcinogenesis induced by alkylating agents. Biochim Biophys Acta 823: 111-145 (1985).

62. Kyrtopoulos SA, Anderson LM, Chhabra SK, Souliotis VL, Pletsa V, Valavanis C, Georgiadis P. DNA adducts and the mechanism of carcinogenesis and cytotoxicity of methylating agents of environmental and clinical significance. Cancer Detect Prev 21: 391-405 (1997).

63. The EUROGAST Study Group. O6-methylguanine in blood leucocyte DNA: an association with the geographic prevalence of gastric cancer and with low levels of serum pepsinogen A, a marker of severe chronic atrophic gastritis. Carcinogenesis 15 : 1815-1820 (1994).

64. Bartsch H, Spiegelhalder B. Environmental exposure to $\mathrm{N}$-nitroso compounds (NOC) and precursors: an overview. Eur J Cancer Prev 5: 11-18 (1996).

65. Tricker AR. N-nitroso compounds and man: sources of exposure, endogenous formation and occurrence in body fluids. Eur / Cancer Prev 6: 226-268 (1997).

66. Hotchkiss JH. Preformed N-nitroso compounds in foods and beverages. Cancer Surv 8: 295-321 (1989).

67. Lijinsky W. N-nitroso compounds in the diet. Mutat Re's 443: 129-138 (1999).

68. International Agency for Research on Cancer. IARC Monographs on the evaluation of the carcinogenic risk of chemicals to humans: some naturally occurring substances: food items and constituents, heterocyclic aromatic amines and mycotoxins. Volume 56. IARC, Lyon (1993). 
69. Ohshima $\mathrm{H}$, Bartsch $\mathrm{H}$. Chronic infections and inflammatory processes as cancer risk factors: possible role of nitric oxide in carcinogenesis. Mutat Res 305: 253-264 (1994).

70. Morton JEN, Margison GP. Increased O6-alkylguanine alkyltransferase activity in Chinese hamster V79 cells following selection with chloroethylating agents. Carcinogenesis 9: 45-49 (1988).

71. Deng C, Xie D, Capasso H, Zhao Y, Wang LD, Hong JY. Genetic polymorphism of human O6-alkylguanine-DNA alkyltransferase: identification of a missense varation in the active site region. Pharmacogenetics 9: 81-87 (1999).

72. Kaur TB, Travaline JM, Gaughan JP, Richie JP Jr, Stellman SD, Lazarus P. Role of polymorphisms in codons 143 and 160 of the O6-alkylguanine DNA alkyltransferase gene in lung cancer risk. Cancer Epidemiol Biomarkers Prev 9: 339-342 (2000).

73. Bartsch H, Ohshima H, Pignatelli B. Inhibitors of endogenous nitrosation. Mechanisms and implications in human cancer prevention. Mutat Res 202: 307-324 (1988).

74. Ohshima $\mathrm{H}$, Bartsch $\mathrm{H}$. Quantitative estimation of endogenous nitrosation in humans by monitoring $N$-nitrosoproline excreted in the urine. Cancer Re's 41: 36583662 (1981).

75. Ohshima H, Bartsch H. In: Counsell JN, Hornig DH. Vitamin C (Ascorbic Acid). Applied Science Publishers, London, 215-224 (1981).

76. Wu YN, Wang $\mathrm{HZ}$, Li JS, Han C. The inhibitory effect of Chinese tea and its polyphenols on in vitro and in vivo N-nitrosation. Biomed Environ Sci 6: 237-258 (1993).

77. Wagner DA, Shuker DEG, Bilmazes C, Obiedzinski M, Baker I, Young VR, Tannenbaum SR. Effects of vitamins $C$ and $E$ on endogenous synthesis of $N$ nitrosamino acids in humans: precursor-product studies with $\left[{ }^{15} \mathrm{~N}\right]$ nitrate. Cancer Res 45: 6519-6522 (1985).

78. Garland WA, Kuenzig W, Rubio F, Kornychuk H, Norkus EP, Conney AH. Urinary excretion of nitrosodimethylamine and nitrosoproline in humans: interindividual and intraindividual differences and the effect of administered ascorbic acid and alpha-tocopherol. Cancer Res 46: 5392-5400 (1986).

79. De Kok T, Van Maanen JMS. Evaluation of fecal mutagenicity and colorectal cancer risk. Mutat Res 463: 53-101 (2000).

80. Van Maanen JMS, Pachen DMFA, Dallinga JW, Kleinjans JCS. Formation of nitrosamines during consumption of nitrate- and amine-rich foods, and the influence of the use of mouthwashes. Cancer Detect Prevent 22: 204-212 (1998). 


\section{Chapter 2}

\section{Determination of $\mathrm{N}$-nitrosodimethylamine in artificial gastric juice by gas chromatography-mass spectrometry and by gas chromatography-thermal energy analysis}

Based on: J.W. Dallinga'

C.A.M. Krul ${ }^{2}$

A.Tenfelde $e^{2}$

E.J.C. Moonen'

I.T.M. Vermeer ${ }^{1}$

D. van Doorn

R.C. Schothorst ${ }^{3}$

Submitted for publication

'Department of Health Risk Analysis and Toxicology, Maastricht University, P.O. Box 616, 6200 MD Maastricht, The Netherlands 2 TNO Nutrition and Food, P.O. Box 360, 3700 AJ Zeist, The Netherlands

${ }^{3}$ Laboratory for Residue Analysis, National Institute of Public Health and the Environment (RIVM), P.O. Box 1, 3720 BA Bilthoven, The Netherlands 


\begin{abstract}
The thermal energy analyzer (TEA) is considered to be the golden standard in the determination of nitrosamines. However, since many laboratories do not have enough applications for such a very specific detection system, alternative detection methods could be useful. While standard gas chromatography (GC) detectors lack the specificity of the TEA detector, mass spectrometry (MS) seems to be the method of choice to combine GC separation with mass specific detection. Moreover, the detection limits in the used GC-MS assay are about 4 times lower than in the GC-TEA assay. A comparison of GC-MS and GC-TEA data of Nnitrosodimethylamine determinations showed a strong correlation between the two assays $\left(R^{2}=0.86\right)$, demonstrating the exchangeability of both methods.
\end{abstract}




\section{Introduction}

Thermal energy analysis is widely applied for the detection of nitrosamines, both in a standalone set-up (1-3) and as a detection system in combination with gas chromatography (4-6) or high performance liquid chromatography (7-9). The strength of this detection system, being its specificity for nitrosamines and related compounds, is also its weakness: many laboratories, which have no regular application in the nitrosamine field, will not have such an instrument available.

GC-MS apparatus is much more current at the modern bioscientific laboratories and could provide an alternative to the classical TEA method for nitrosamine determination. In a few papers we described the application of the GC-MS system for the determination of volatile nitrosamines in body fluids (1013). A complementary advantage, and for our regular investigations necessary condition of this method, is the lower detection limit.

In the present study we compare the results of N-nitrosodimethylamine (NDMA) determination in artificial gastric juice at levels detectable with both the TEA and the MS detectors. The aim of this comparison is not to elucidate which method would be the method of preference, but to compare both methods used, including sample preparation at the routinely applied conditions in the two laboratories. Therefore, 56 samples from a larger study involving the formation of volatile nitrosamines in a dynamic gastrointestinal tract model were analyzed at both systems. The results of the whole study will be published elsewhere, but the data of the samples analyzed at both systems are presented and discussed here.

\section{Materials and methods}

\section{Samples}

The samples were derived from experiments with the dynamic, computer controlled TNO in vitro gastro-intestinal tract model (TIM). Details of this model have been described elsewhere $(14,15)$. In short: NDMA was formed under various controlled conditions in the stomach compartment of the TIM by simulating the nitrosation of dimethylamine at physiological conditions. Peristaltic movements mixed the contents of the stomach, which contained dimethylamine, nitrite, $\mathrm{NaCl}(3.1 \mathrm{~g} / 1), \mathrm{KCl}(1.1 \mathrm{~g} / \mathrm{l}), \mathrm{CaCl}_{2} \cdot 2 \mathrm{H}_{2} \mathrm{O}(0.15 \mathrm{~g} / \mathrm{l})$, $\mathrm{NaHCO}_{3}(0.6 \mathrm{~g} / \mathrm{l})$, and the digestion enzymes lipase and pepsin. The contents were delivered to the duodenum were the $\mathrm{pH}$ was continuously monitored and kept at $\mathrm{pH}>10$ by adding $10 \mathrm{~N} \mathrm{NaOH}$ solution. Because of potential degradation of nitrosamines the TIM was protected from UV light and flushed with nitrogen. The samples were retracted from the model, collected on ice, split in portions and stored at $-70^{\circ} \mathrm{C}$ and in the dark until analysis. Of each sample one portion was 
analyzed by GC-TEA at the Laboratory for Residue Analysis of the National Institute of Public Health and the Environment and another by GC-MS at the Department of Health Risk Analysis and Toxicology at Maastricht University.

\section{GC-TEA determination}

The samples were thawed till room temperature and $5 \mathrm{~g}$ was fortified with $100 \mu \mathrm{l}$ of an internal standard solution of $3 \mathrm{mg} / \mathrm{l} \mathrm{N}$-nitrosodiisopropylamine in ethanol. The resulting solution was homogeneously mixed with $5 \mathrm{~g}$ of celite. This mixture was placed on top of a chromatography column containing $20 \mathrm{~g}$ anhydrous sodium sulphate. The column was eluted with $50 \mathrm{ml}$ dichloromethane. The eluent was concentrated to $3 \mathrm{ml}$ using a K-D evaporate concentrator and further to $0.5 \mathrm{ml}$ using a micro $\mathrm{K}-\mathrm{D}$ device at $60^{\circ} \mathrm{C}$ and next cooled to room temperature. The resulting concentrate was transferred to a glass vessel with teflon-lined septum and stored at $-30^{\circ} \mathrm{C}$ until analysis. Before injecting in the GC-TEA system, samples were brought to ambient temperature and per analysis $5 \mu \mathrm{l}$ were injected. The GC used was a Fisons 8160 gas chromatography system, equipped with a AS 8000 autosampler with a cold on column injection system, a Rtx-1701 (14\% cyanopropylphenyl, $86 \%$ dimethylpolysiloxane) column of $30 \mathrm{~m}$ length, $0.53 \mathrm{~mm}$ ID, $1.5 \mu \mathrm{m}$ film thickness. The injection port temperature was $60^{\circ} \mathrm{C}$, column temperature 2 minutes at $60^{\circ} \mathrm{C}$ and then programmed from $60^{\circ} \mathrm{C}$ to $200^{\circ} \mathrm{C}$ at a ramp rate of $20^{\circ} \mathrm{C} /$ minute, hold for 10 minutes and then programmed from $200^{\circ} \mathrm{C}$ to $220^{\circ} \mathrm{C}$ at a ramp rate of $20^{\circ} \mathrm{C} /$ minute and hold for 2 minutes. Helium was used as the carrier gas at a flow rate of $20-25 \mathrm{ml} /$ minute. The GC was coupled to a thermal energy analyzer, model 543 (Thermal Electron Company, Waltham, Massachusetts USA) via a heated interface at $200^{\circ} \mathrm{C}$. The TEA was operated at a pressure of $1.0-1.3 \mathrm{~mm} \mathrm{Hg}$ at a pyrolyzer temperature of $550^{\circ} \mathrm{C}$. The amounts of NDMA were calculated using the peak areas of NDMA, a calibration curve for NDMA, and the internal standard. The detection limit of the method was about 80 pg of NDMA injected, corresponding to $1.6 \mu \mathrm{g} / \mathrm{kg}$ (surrogate) gastric juice.

\section{GC-MS determination}

The samples were brought to ambient temperature and $5 \mathrm{ml}$ portions of the samples were extracted with $1 \mathrm{ml}$ of dichloromethane. The extracts were stored at $-20^{\circ} \mathrm{C}$ until analysis. For the analysis, $0.5 \mu \mathrm{l}$ of the dichloromethane solutions were splitlessly injected in a HP5890 Series II gas chromatograph (Hewlett-Packard, Portland, Oregon USA), injector temperature $265^{\circ} \mathrm{C}$, using a $25 \mathrm{~m}, \mathrm{I} . \mathrm{D} .0 .32 \mathrm{~mm}$, film thickness $0.25 \mu \mathrm{m}$ fused silica SGE BPX5 column (SGE, Inc., Austin, Texas USA). The column temperature was $50^{\circ} \mathrm{C}$ for five minutes, then rising to $200^{\circ} \mathrm{C}$ at $10^{\circ} \mathrm{C} /$ minute, at $200^{\circ} \mathrm{C}$ for two minutes and then rising at $30^{\circ} \mathrm{C} /$ minute to $300^{\circ} \mathrm{C}$. Helium was used as the carrier gas at a flow rate of $1 \mathrm{ml} / \mathrm{minute}$. The column ended inside the ion source of the double focussing mass spectrometer of reversed 
geometry (Jeol-SX102A, JEOL Ltd., Tokyo Japan), which was operated in the electron ionization (EI) mode, with an ionizing energy of $70 \mathrm{eV}$ and an ion source temperature of $200^{\circ} \mathrm{C}$, and set at a mass resolution of 1000 at $10,000 \mathrm{~V}$ accelerating voltage. The molecular ions $\left(\mathrm{M}^{+}\right)$of NDMA were detected by single ion monitoring (SIM). This way, a maximum sensitivity is combined with an optimum selectivity. Quantification was performed using an absolute working curve. The limit of detection was roughly $1 \mathrm{pg}$ injected, which corresponds to 0.4 $\mu \mathrm{g} / \mathrm{l}$ gastric juice. In order to prevent saturation effects the samples were diluted prior to injection in the GC where necessary.

\section{Statistical methods}

Correlations were determined using linear regression analysis.

\section{Results and discussion}

The quantities of NDMA in the various samples found with both methods varied between $0-2200 \mu \mathrm{g} / 1$ (GC-MS) and $10-3500 \mu \mathrm{g} / 1$ (GC-TEA). Linear regression analysis of the data showed systematically about 1.1 times higher values for the GC-TEA data when compared to the GC-MS data, indicating a difference in the accuracy but not in the precision of the two methods. The linear regression relationship is represented by the formula: [NDMA] (GC-TEA) $=1.126$ * [NDMA] $(\mathrm{GC}-\mathrm{MS})+10.49\left(\mathrm{n}=56, \mathrm{R}^{2}=0.86, \mathrm{p}=0.0001\right)$; the plot of this relationship is presented in Figure 1a. However, the differences in results are more pronounced at the highest concentrations; therefore, we also calculated and presented the correlation at a reduced concentration interval. The regression line for NDMA concentrations $<175 \mu \mathrm{g} / \mathrm{l}$ (GC-MS data) is presented in Figure 1b. From these data it is clear that despite the rather different sample extraction and clean-up methods applied, the quality of the data obtained with both methods is very well comparable at a concentration range up to $175 \mu \mathrm{g} / 1$ (GC-MS data).

We acknowledge that for analytical purposes the differences in absolute quantities detected with both methods should be diminished. However, for relative quantitative information within a series of biological samples, both methods give very well comparative results, which would lead to the same conclusions. One of the advantages of the GC-TEA assay is the use of larger extraction volumes combined with controlled concentration of the organic solution. We anticipate an improved yield and, consequently, an even improved correspondence between the two assays, when this would also be implemented in the GC-MS assay. However, besides the low detection limit, the high speed sample preparation is an important advantage of the present GC-MS assay, which would be lost that way. 

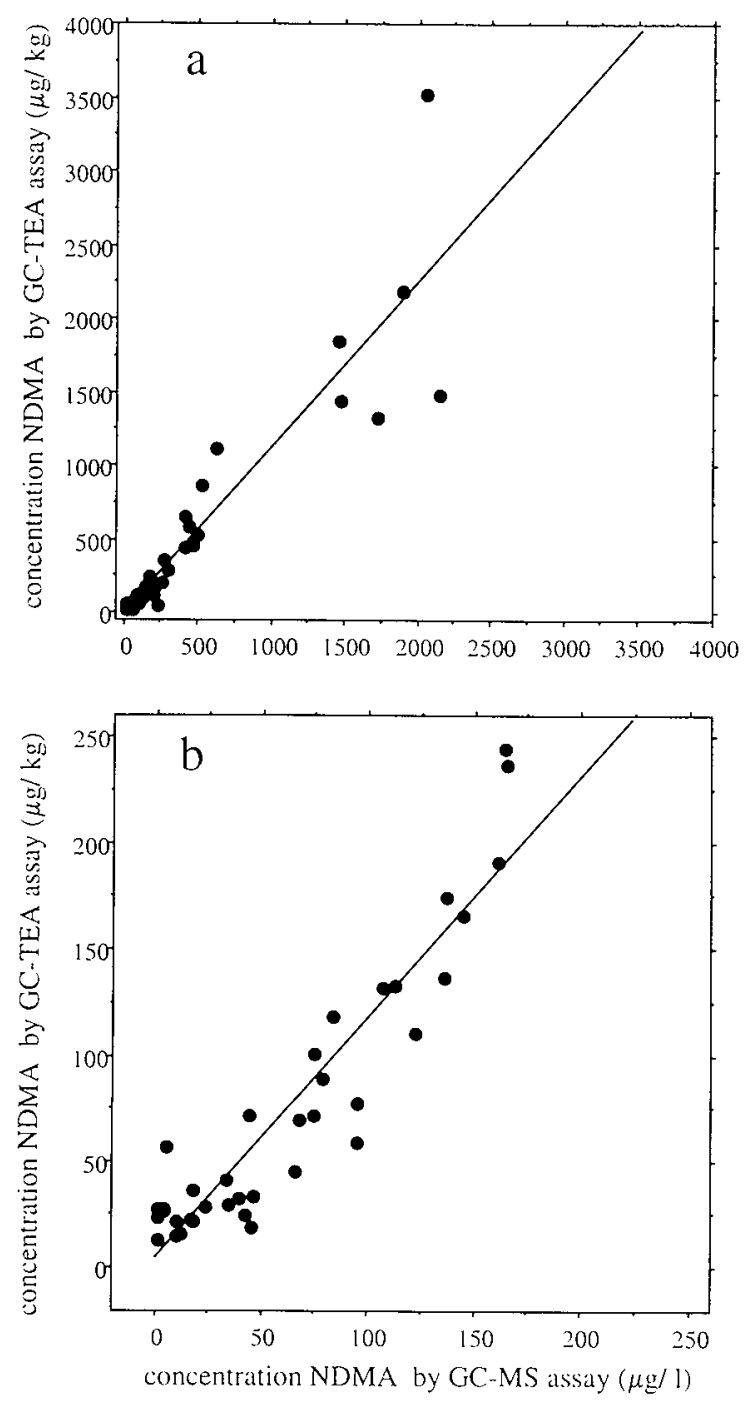

Figure 1. Plots of NDMA concentrations in artificial gastric juice as determined by GCMS assay ( $x$-axis) versus GC-TEA assay ( $y$-axis) at various concentration intervals.

a: all data, $\mathrm{n}=56, \mathrm{R}^{2}=0.86, \mathrm{p}=0.0001$; regression line $\mathrm{y}=1.126 \mathrm{x}+10.49$

$\mathrm{b}: \mathrm{x}<175, \mathrm{n}=37, \mathrm{R}^{2}=0.86, \mathrm{p}=0.0001$; regression line $\mathrm{y}=1.131 \mathrm{x}+5.28$ 


\section{Conclusion}

Comparison of the two assays for the determination of volatile nitrosamine as applied at the two laboratories involved, demonstrates the applicability of either of the methods for relative quantitation and kinetic measurements. The correspondence between the two techniques could even be improved by standardizing the sample preparation prior to GC analysis, so that the detection methods would be fully exchangeable.

\section{References}

1. Xu GP, Reed PI. A method for group determination of total N-nitroso compounds and nitrite in fresh gastric juice by chemical denitrosation and thermal energy analysis. Analyst 118: 877-883 (1993).

2. Massey RC, Key PE. An investigation of the endogenous formation of apparent total $\mathrm{N}$-nitroso compounds in conventional microflora and germ-free rats. Fd Chem Toxic 26: 595-600 (1988).

3. Pignatelli B, Richard I, Bourgade MC, Bartsch H. Improved group determination of total N-nitroso compounds in human gastric juice by chemical denitrosation and thermal energy analysis. Analyst 112: $945-949$ (1987).

4. Mostafa MH, Helmi S, Badawi AF, Tricker AR, Spiegelhalder B, Preussmann R. Nitrate, nitrite and volatile $\mathrm{N}$-nitroso compounds in the urine of Schistosoma haematobium and Schistosoma mansoni infected patients. Carcinogenesis 15: 619-625 (1994).

5. Calmels S, Béréziat JC, Ohshima H, Bartsch H. Bacterial formation of N-nitroso compounds from administered precursors in the rat stomach after omeprazoleinduced achlorhydria. Carcinogenesis 12: 435-439 (1991).

6. Perciballi M, Hotchkiss JH. In vivo inhibition of N-nitrosodimethylamine metabolism by 4-methylpyrazole: a model for endogenous nitrosation. Carcinogenesis 10: 23032309 (1989).

7. Havery DC. Determination of N-nitroso compounds by high-performance liquid chromatography with postcolumn reaction and a thermal energy analyzer. I Anal Toxicol 14: 181-185 (1990).

8. Kubacki S], Havery DC, Fazio T. HPLC analysis of N-nitrosamino acids and Nnitrosodipeptides N-terminal in proline. Z Gesamte. Hyg 35: 98-100 (1989).

9. Fine DH, Rounbehler DP, Yu WC, Goff EU. A new Thermal Energy Analyzer for direct high-performance liquid chromatographic and gas chromatographic analysis of N-nitrosamides. IARC Sci Publ 57: 121-129 (1984).

10. Vermeer ITM, Moonen EJC, Dallinga JW, Kleinjans JCS, van Maanen JMS. Effect of ascorbic acid and green tea on endogenous formation of N-nitrosodimethylamine and N-nitrosopiperidine in humans. Mutat Res 428: 353-361 (1999).

11. Dallinga JW, Pachen DMFA, Lousberg AHP, van Geel JA, Houben GM, Stockbrugger RW, van Maanen JMS, Kleinjans JCS. Volatile N-nitrosamines in gastric juice of patients with various conditions of the gastrointestinal tract 
determined by gas chromatography-mass spectrometry and related to intragastric $\mathrm{pH}$ and nitrate and nitrite levels. Cancer Lett 124: 119-125 (1998).

12. Van Maanen JMS, Pachen DMFA, Dallinga JW, Kleinjans JCS. Formation of nitrosamines during consumption of nitrate- and amine-rich food and the influence of the use of mouthwashes. Cancer Detect Prev 22: 204-212 (1998).

13. Dallinga JW, Pachen DMFA, Kleinjans JCS. Determination of volatile Nnitrosamines in gastric juice and in urine by gas chromatography-mass spectrometry. Eur J Cancer Prev 5: 63-66 (1996).

14. Minekus M, Havenaar R. Eur Patent Bul 98/07, Art. 97: 4-5 (1998).

15. Minekus M, Marteau P, Havenaar R, in 't Veld JHJ. A multicompartmental dynamic computer-controlled model simulating the stomach and small intestine. Altern Lab Anim 23: 197-209 (1995). 


\section{Chapter 3}

\section{Volatile N-nitrosamine formation after intake of nitrate at the ADI level in combination with an amine-rich diet}

I.T.M. Vermeer

D.M.F.A. Pachen

J.W. Dallinga

J.C.S. Kleinjans

J.M.S. van Maanen

Environmental Health Perspectives 106: 459-463 (1998)

Department of Health Risk Analysis and Toxicology, Maastricht University, P.O. Box 616, 6200 MD Maastricht, The Netherlands 


\begin{abstract}
Formation of nitrite from ingested nitrate can result in several adverse health effects and implies a genotoxic risk as a consequence of endogenous formation of carcinogenic N-nitroso compounds. We studied the formation of volatile $\mathrm{N}$ nitrosamines after intake of nitrate at the acceptable daily intake (ADI) level in combination with a fish meal rich in amines as nitrosatable precursors. Twentyfive volunteers consumed this meal during 7 consecutive days; a diet low in nitrate was consumed during 1 week before and 1 week after the test week. Nitrate intake at the ADI level resulted in a significant rise in mean salivary nitrate and nitrite concentrations. Mean urinary nitrate excretion increased from $76 \mathrm{mg} / 24 \mathrm{hr}$ in the first control week to 194 and $165 \mathrm{mg} / 24 \mathrm{hr}$ in the test week, followed by a decline to $77 \mathrm{mg} / 24 \mathrm{hr}$ in the second control week. The urine samples were analyzed for volatile $\mathrm{N}$-nitrosamines, and both $\mathrm{N}$-nitrosodimethylamine (NDMA) and N-nitrosopiperidine (NPIP) were detected in the samples. Mean urinary NDMA excretion significantly increased from $287 \mathrm{ng} / 24 \mathrm{hr}$ in the control week to 871 and $640 \mathrm{ng} / 24 \mathrm{hr}$ in the test week, and declined to $383 \mathrm{ng} / 24$ hr in the second control week. Excretion of NPIP was not directly related to the nitrate intake and composition of the diet. Nitrate excretion and NDMA excretion were significantly correlated, as well as salivary nitrate and nitrite concentration and NDMA excretion. We conclude that nitrate intake at the ADI level in combination with a fish meal containing nitrosatable precursors increases NDMA excretion in urine and thus demonstrates increased formation of carcinogenic Nnitrosamines.
\end{abstract}




\section{Introduction}

Humans are exposed to nitrate mainly as a consequence of food intake and, to a lesser extent, of drinking water consumption. Vegetables are the principal source of nitrate exposure, providing at least $85 \%$ of the average daily nitrate intake when the drinking water nitrate concentration is low (e.g. 1-5 mg/l). The contribution of drinking water intake to the nitrate load is strongly dependent on the type of water supply. The World Health Organization (WHO) guidelines indicate a maximally admissible nitrate concentration in drinking water of 44.3 $\mathrm{mg} / \mathrm{l}$ (1). Nitrate levels in most European public drinking water supplies seldom exceed $45 \mathrm{mg} / \mathrm{l}$. Private wells, however, may contain as much as $300 \mathrm{mg} / \mathrm{l}$ (2). WHO states that nitrate levels in surface waters and groundwaters have markedly increased in the last decades due to increased use of fertilizers, changes in land use, and disposal of waste from intensive animal farming, leading to an increased risk of human exposure (1).

Nitrate per se is relatively nontoxic, but approximately $5 \%$ of all ingested nitrate is converted to the more toxic nitrite (3-5). Upon absorption in the bloodstream, nitrite reacts with hemoglobin to form methemoglobin, which is unable to transport oxygen (6). Methemoglobinemia is considered to be the major human health risk associated with nitrate exposure. Infants are especially sensitive to the formation of methemoglobin. Based on the no-adverse-effect level observed in animal studies, WHO has set the acceptable daily intake (ADI) for nitrate and nitrite at, respectively, $3.67 \mathrm{mg} / \mathrm{kg}$ body weight and $0.13 \mathrm{mg} / \mathrm{kg}$ body weight (expressed as nitrate and nitrite ion) (7).

Other adverse health effects of nitrate exposure have been reported. Exposure to high nitrate levels implies a genotoxic risk for humans due to endogenous formation of carcinogenic N-nitroso compounds. Nitrite derived from nitrate may react in vivo with amines and amides to form N-nitroso compounds. About $300 \mathrm{~N}$-nitroso compounds (NOC) have been tested for carcinogenicity in experimental animals; $85 \%$ of the 209 nitrosamines and $92 \%$ of the 86 nitrosamides have been shown to be carcinogenic in a variety of species (8). Human exposure to endogenously formed NOC has been associated with an increased risk of cancer of the stomach, esophagus, and bladder (9-12). Convincing epidemiological evidence for human cancer risk, however, is still lacking. Ward et al. (13) observed that long-term exposure to elevated nitrate levels in drinking water may contribute to the risk of non-Hodgkin's lymphoma. Lin and Ho (14) reported hepatocarcinogenic effects in rats of endogenously formed NOC after dietary intake of amines in combination with nitrite. Studies with patient groups point to a role for NOC in human cancer (15). On the other hand, several studies reported no or even an inverse relationship between nitrate or NOC and human cancer (16-18). 
$N$-nitrosoproline excretion in urine is frequently used as an indicator of endogenous nitrosation (NPRO test) (19-22). However, limited information is available on excretion of individual (carcinogenic) nitrosamines. In a recent study, we observed an increase in peripheral lymphocyte hprt (hypoxanthine-guanine phosphoribosyltransferase) variant frequency in users of well water containing high levels of nitrate, in combination with relatively high urinary excretion levels of the carcinogenic N-nitrosodimethylamine (NDMA), N-nitrosodiethylamine (NDEA), N-nitrosopiperidine (NPIP), and N-nitrosopyrrolidine (NPYR) (23).

The aim of the present study was to investigate nitrosamine formation after nitrate exposure at the ADI level. This paper describes the excretion of volatile nitrosamines in the urine of human volunteers after a nitrate load in water in combination with a fish meal, since fish contains high amounts of amines, which are nitrosatable precursors $(24,25)$. This study can contribute to the discussion of the validity of the current ADI of nitrate and nitrite for preventing human health risks.

\section{Materials and methods}

\section{Study population and protocol.}

Twenty-five healthy women volunteered to participate and signed an informed consent. They agreed to donate saliva samples, collect 24 -hr urine, and to answer a questionnaire on food consumption and lifestyle habits. The participants were nonsmokers and used no medicine or vitamin preparations. The mean weight of the volunteers $( \pm S D$ ) was $60 \pm 6 \mathrm{~kg}$ (range $48-75 \mathrm{~kg}$ ) and the mean age was $23 \pm 7$ years (range $18-46$ years).

The study period consisted of 3 weeks: week 1 was a control week (control week 1), week 2 the experimental week, and week 3 was a control week (control week 2). During the control weeks the subjects refrained from consuming high nitrate-containing food items; on day 7 a $2-\mathrm{ml}$ saliva sample was taken ( $2 \mathrm{hr}$ after dinner) and 24-hr urine was collected. During the experimental week, the participants received a dinner low in nitrate and containing fish (cod, salmon, shrimp, pollack) at the University of Maastricht, in combination with a $\mathrm{KNO}$, solution in water $\left(277 \mathrm{mg} \mathrm{KNO}_{3}\right.$, corresponding to $170 \mathrm{mg}$ nitrate ion, in $100 \mathrm{ml}$ of destilled water). A nitrate load in water was used instead of nitrate-containing vegetables because this was the most suitable method of giving the volunteers the exact same dose every day. The total nitrate dose was at the ADI level for a person with a body weight of $60 \mathrm{~kg}$ (the mean body weight of the participants). Assuming a conservative nitrate intake of $50 \mathrm{mg} /$ day, even with a diet low in nitrate, the volunteers consumed $170 \mathrm{mg}$ of nitrate in water, resulting in a nitrate dose of $220 \mathrm{mg}$ per day. On days 3 and 7,2 $\mathrm{ml}$ saliva samples were taken at 1,2,5, 
and $23 \mathrm{hr}$ after nitrate intake. Twenty-four-hour urine was collected every day, and the volume of the urine was recorded. Urines of days 1, 2, and 3 were pooled, and a $100-\mathrm{ml}$ sample was taken; also urines of days $4-7$ were pooled and sampled.

Collection and storage of saliva and urine samples.

Two-milliliter saliva samples were produced after stimulating the salivary flow by chewing on parafilm and were collected in plastic vials in which $0.2 \mathrm{ml} 1 \mathrm{M}$ $\mathrm{NaOH}$ had been evaporated to dryness for stabilization of nitrate and nitrite. The 24-hr urine samples were collected in 2-l containers with $10 \mathrm{~g} \mathrm{NaOH}$ pellets. Saliva and urine samples were stored at $-20^{\circ} \mathrm{C}$ until analysis.

Analysis of nitrate in fish meals.

The meals were homogenized, and $10 \mathrm{~g}$ were used for nitrate analysis. Sample preparation and analysis were performed as described in the instructions of the Boehringer Mannheim Nitrate Kit no. 905658 (26).

Analysis of nitrate and nitrite in saliva.

Saliva samples were deproteinized by adding $50 \mu \mathrm{l} 1 \mathrm{M} \mathrm{ZnSO}_{4}$ to $0.5 \mathrm{ml}$ of saliva. The mixture was vortexed, placed on ice for $15 \mathrm{~min}$, and centrifuged for $10 \mathrm{~min}$ at $12,000 \mathrm{~g}$. The supernatant was heated at $100^{\circ} \mathrm{C}$ for $10 \mathrm{~min}$ for further deproteinization. After centrifugation for $10 \mathrm{~min}$ at $12,000 \mathrm{~g}$, the nitrate and nitrite concentrations in the supernatant were determined by HPLC using anionexchange chromatography as previously described (27).

\section{Analysis of nitrate and nitrite in urine.}

One milliliter of urine was centrifuged for $10 \mathrm{~min}$ at $12,000 \mathrm{~g}$, and $50 \mu 1$ of the supernatant was analyzed for nitrate content with the spectrophotometric method from Boehringer (Boehringer Mannheim Kit no. 905658) using nitrate reductase (26). We calculated the amount of nitrate excreted in urine by multiplying the urinary nitrate concentration with the volume of the 24-hr urine. Urine samples were screened for nitrite content with nitrite test strips (Merckoquant nitrit-test; Merck, Germany).

Analysis of volatile nitrosamines in urine.

Volatile nitrosamines, as listed in Table 1, were determined by gas chromatography mass spectrometry (GC-MS) as previously described (23) with some modifications. A $20-\mathrm{ml}$ urine aliquot was extracted with $1 \mathrm{ml}$ of dichloromethane; $0.5 \mu \mathrm{l}$ of the dichloromethane solution was splitlessly injected into the GC-MS system, consisting of an HP5890 Series II gas chromatograph (Hewlett-Packard, Avondale, Pennsylvania) and a Jeol SX102A mass spectrometer (Jeol Ltd., Tokyo). The column used was a WCOT fused silica column 
(Chrompack, New Jersey), length $50 \mathrm{~m}$, I.D. $0.25 \mathrm{~mm}$, stationary phase (P-Sil-8 CB-MS, and film thickness $0.25 \mu \mathrm{m}$. Helium was used as the carrier gais (1 $\mathrm{ml} / \mathrm{min}$ ), and the injector temperature was $250^{\circ} \mathrm{C}$. The column temperature was $50^{\circ} \mathrm{C}$ for $0.8 \mathrm{~min}$, then rising to $100^{\circ} \mathrm{C}$ at $9^{\circ} \mathrm{C} / \mathrm{min}$. After $0.5 \mathrm{~min}$ at $100^{\circ} \mathrm{C}$, the temperature rose to $290^{\circ} \mathrm{C}$ at $35^{\circ} \mathrm{C} / \mathrm{min}$ and was maintained at $290^{\circ} \mathrm{C}$ for $5 \mathrm{~min}$. The mass spectrometer generated ions by electron ionization at $70 \mathrm{eV}$. The molecular ions $\left(\mathrm{M}^{*}\right)$ were detected using high-resolution (3000) single-ion monitoring (HR-SIM). Both retention time and elemental composition of the ions were used as proof of the identity of the measured components. Quantification was performed by a calibration curve for each of the nitrosamines, using a nitrosamine mixture for EPA method 8270 (Aldrich, Zwijndrecht, the Netherlands). The calibration curves (in urine) were analyzed analogously to the samples, adjusting for a possible loss of nitrosamines during workup. The detection limit for each nitrosamine was $1 \mathrm{pg} / \mu \mathrm{l}$ of dichloromethane solution, corresponding to $50 \mathrm{pg} / \mathrm{ml}$ of urine.

Table 1 . The five $\mathrm{N}$-nitrosamines analyzed in urine

\begin{tabular}{lll}
\hline N-Nitrosamine & $\begin{array}{l}\mathrm{M}^{+} \cdot \text { ion } \\
(\mathrm{m} / \mathrm{z})\end{array}$ & $\begin{array}{l}\text { Retention time } \\
(\mathrm{min})\end{array}$ \\
\hline N-Nitrosodimethylamine (NDMA) & 74.05 & 3.6 \\
N-Nitrosomethylethylamine (NMEA) & 88.06 & 4.7 \\
N-Nitrosodiethylamine (NDEA) & 102.08 & 5.85 \\
N-Nitrosopiperidine (NPIP) & 114.08 & 8.93 \\
N-Nitrosomorpholine (NMOR) & 116.06 & 8.50 \\
\hline
\end{tabular}

In our previous study, we mainly detected N-nitrosopyrrolidine in urine samples from subjects exposed to drinking water with medium or high nitrate levels (23). However, in a recent study with volunteers consuming meals with fish and vegetables rich in nitrate and using mouthwashes, we predominantly detected NDMA and no NPYR (28). Therefore, in this study with comparable nitrosating precursors, the GC-MS run detecting five volatile nitrosamines after one injection including NDMA and excluding NPYR was performed.

\section{Statistical methods.}

Results are expressed as means \pm SD. Statistical comparisons of the data with respect to nitrate and nitrite concentrations in saliva, nitrate reduction, and nitrate 
and nitrosamine excretion in urine were performed by the nonparametric Wilcoxon signed-ranks test. A p-value $<0.05$ was considered significant, except for NDMA excretion in urine, where the $p$-value was compared with an adjusted $\alpha$ of 0.01 because five comparisons were made within one set of data (29).

We used linear regression analysis to examine the relationship between nitrate and nitrosamine excretion in urine and between the log transformed nitrate and nitrite concentration in saliva, and nitrate and nitrosamine excretion in urine and between nitrate reduction and nitrosamine excretion in urine. A p-value $<0.05$ was considered significant.

\section{Results}

The mean nitrate intake via the fish meals consumed during the test week was 17 $\pm 15 \mathrm{mg}$. The nitrate content of the meals consumed during days 1-3 was slightly higher than the nitrate content of the meals consumed during days 4-7 (mean nitrate content 21 and $13 \mathrm{mg}$, respectively).

Nitrate and nitrite concentrations in saliva increased significantly after intake of nitrate at the ADI level (Fig. la and 1b). Peak levels of both nitrate and nitrite were observed $1 \mathrm{hr}$ after nitrate ingestion. Nitrate concentrations reached a maximum value of $202 \pm 80 \mathrm{mg} / \mathrm{l}$ (mean \pm SD) at day 3 and $192 \pm 107 \mathrm{mg} / \mathrm{l}$ at day 7. Maximum nitrite levels were $32 \pm 18 \mathrm{mg} / \mathrm{l}$ at day 3 and $32 \pm 19 \mathrm{mg} / \mathrm{l}$ at day 7 . Nitrate and nitrite levels $2 \mathrm{hr}$ after nitrate intake were significantly increased compared with levels $2 \mathrm{hr}$ after a meal low in nitrate during the control weeks (Wilcoxon, $\mathrm{p}<0.0016$ ). Twenty-three hours after nitrate intake, salivary nitrate and nitrite concentrations had decreased to baseline levels.

A significant difference was observed between nitrate reduction levels (at 2 hr after the meal) during the control weeks and during the test week (Wilcoxon, $\mathrm{p}$ $=0.0011$ ). Nitrate reduction during the control weeks was $25 \pm 15 \%$ and during the test week was $18 \pm 11 \%$.

Table 2 presents data on nitrate excretion in urine. Mean 24-hr nitrate excretion increased significantly during the test week compared with the control weeks ( $p=0.0001$ ). Nitrate excretion in the test week, during days 1-3 and days 47 , expressed as percentage of the total nitrate dose (220 mg/day), was 88 and $75 \%$, respectively. Nitrite was not detected in the urine samples. 

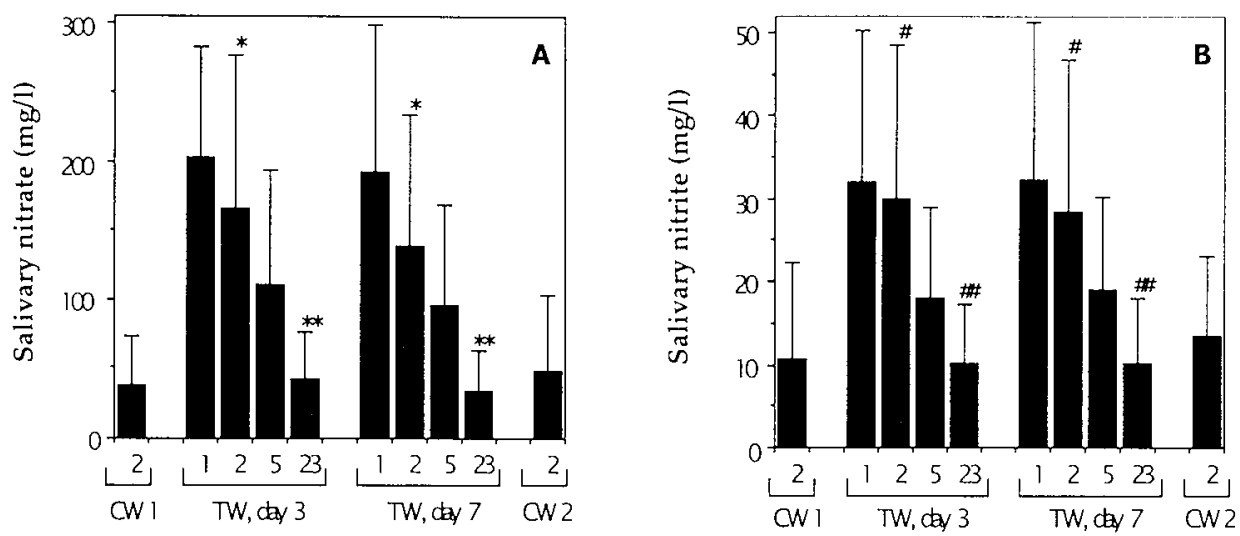

Time after the meal with (TW) or without (CW) nitrate intake (hr)

Figure 1. (A) Mean ( \pm standard deviation) salivary nitrate concentrations (mg/l); (B): mean salivary nitrite concentrations $(\mathrm{mg} / \mathrm{l}) 2 \mathrm{hr}$ after a meal low in nitrate during the control weeks (CW) and 1,2,5, and $23 \mathrm{hr}$ after a meal in combination with nitrate intake at 2 different days during the test week (TW). ${ }^{*}$ Significantly increased compared with CW 1 and CW 2, Wilcoxon, p<0.0004; ** significantly decreased compared with 1, 2 and $5 \mathrm{hr}$ after nitrate intake, Wilcoxon, $\mathrm{p}<0.0004$; \# significantly increased compared with CW 1 and CW 2, Wilcoxon, $\mathrm{p}<0.0016$; \#\# significantly decreased compared with 1, 2 and 5 hr after nitrate intake, Wilcoxon, $\mathrm{p}<0.0011$.

Table 2. Nitrate excretion in urine $(\mathrm{mg} / 24 \mathrm{hr})$ during the study protocol

\begin{tabular}{lll}
\hline & Nitrate excretion in urine & Nitrate excretion \\
Time & $(\mathrm{mg} / 24 \mathrm{hr})$, mean $\pm \mathrm{SD}$ & as \% of total dose
\end{tabular}

Control week 1

$76 \pm 42$
$194 \pm 45^{*}$
$165 \pm 40^{*}$
$77 \pm 41$

Test week, days 4-7

$77 \pm 41$

75

Control week 2

*Significant increase compared with control week 1 and control week 2 (Wilcoxon, $p=0.0001$ ). 
Two N-nitrosamines were detected in urine samples: NDMA and NPIP. The results of NDMA excretion in urine are shown in Figure 2. Mean NDMA excretions during control week 1 , test week days $1-3$, test week days $4-7$, and control week 2 were $287 \pm 223,871 \pm 430,640 \pm 277$, and $383 \pm 168 \mathrm{ng} / 24 \mathrm{hr}$, respectively. One observation (during the test week, days 1-3) was identified as an outlier (more than three times the SD) and was excluded from all analyses. Comparisons were made between NDMA excretions in control week 1 and test week days 1-3, control week 1 and test week days 4-7, control week 1 and control week 2, test week days 1-3 and control week 2, and test week days 4-7 and control week 2. We compared P-values with an adjusted $\alpha$ of 0.010 . A significant increase in NDMA excretion was observed during test week days 1-3 and test week days 4-7 compared with control week 1 and control week $2(p<0.0002)$. There was no significant difference in NDMA excretion between the two control weeks $(\mathrm{p}=$ $0.03)$.

Mean urinary NPIP excretion significantly increased during the study relative to control week 1 . During control week 1 , NPIP excretion was $69 \pm 36$ $\mathrm{ng} / 24 \mathrm{hr}$, followed by an ecretion of $86 \pm 49 \mathrm{ng} / 24 \mathrm{hr}$ during test week days 1-3 (compared with control week 1 ; Wilcoxon, $\mathrm{p}=0.008$ ), $94 \pm 57 \mathrm{ng} / 24 \mathrm{hr}$ during test week days 4-7 (Wilcoxon, $p=0.006$ ), and $104 \pm 55 \mathrm{ng} / 24 \mathrm{hr}$ during control week 2 (Wilcoxon, $\mathrm{p}=0.002$ ). NPIP levels in urine were approximately $4-10$ times lower than NDMA levels.

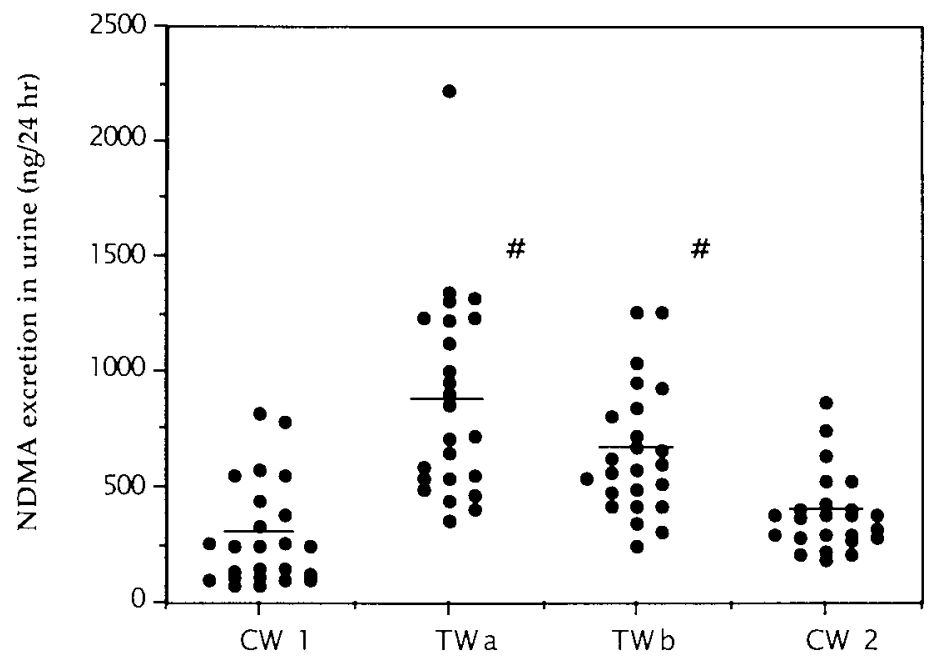

Figure 2. N-nitrosodimethylamine (NDMA) excretion in urine ( $\mathrm{ng} / 24 \mathrm{hr}$ ) of 24 subjects during control weeks (CW 1 and CW 2) and test week days 1-3 and 4-7 (TWa and TWb). \# Significantly increased compared with CW 1 and CW 2; Wilcoxon, $p<0.0002$. 


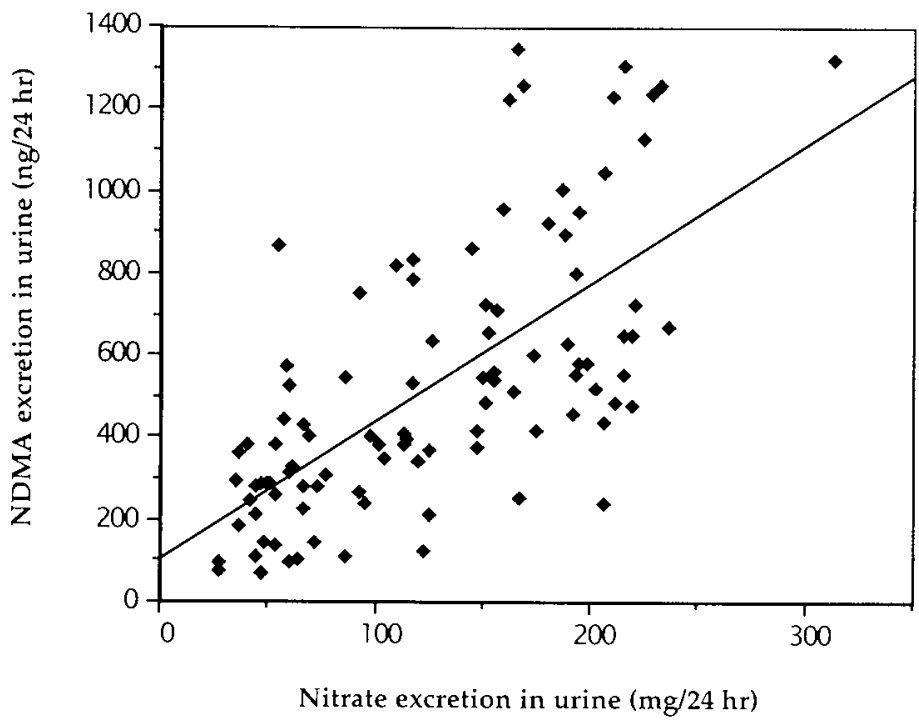

Figure 3. Correlation between nitrate excretion in urine and N-nitrosodimethylamine (NDMA) excretion in urine $(\mathrm{r}=0.68 ; \mathrm{p}=0.0001)$.

Linear regression analyses of the data of all urine samples of test and control weeks showed a significant correlation between urinary nitrate excretion and urinary NDMA excretion ( $r=0.68$ and $p=0.0001$, see Fig. 3). No relationship was observed between nitrate excretion in urine and NPIP excretion in urine; however, a relationship was observed between cumulative nitrate excretion in urine and cumulative NPIP excretion in urine $(r=0.8$ and $p=0.0001)$. Furthermore, a correlation was found between the log of the nitrate concentration in saliva and nitrate excretion in urine $(r=0.70$ and $p=0.0001)$. Finally, correlations were found between log salivary nitrate concentration and NDMA excretion in urine $(r=0.48 ; p=0.0001)$ and between log nitrite concentration in saliva and NDMA excretion in urine $(r=0.40 ; p=0.0001)$. No correlation was observed between nitrate reduction levels and NDMA excretion in urine. 


\section{Discussion}

WHO has set guidelines for nitrate and nitrite intake to prevent the occurrence of methemoglobinemia. Nitrate exposure, however, implies other adverse health effects, including the endogenous formation of carcinogenic N-nitroso compounds. The present study was performed because no information is available about $\mathrm{N}$-nitrosamine formation after nitrate intake at the ADI level. The volunteers in this study received a nitrate dose of $170 \mathrm{mg}$ in drinking water in combination with a fish meal low in nitrate during 1 week. Mean nitrate content of the fish meals was $17 \mathrm{mg} /$ day, and the estimated nitrate content of breakfast, lunch, fruit, and drinking water consumed during the rest of the day was approximately $23 \mathrm{mg} /$ day (8), resulting in a total nitrate dose of $210 \mathrm{mg}$ (estimated range: 185-235 $\mathrm{mg}$ ). This (conservative) nitrate intake will be referred to as the ADI level. Nitrate intake at the ADI level resulted in significantly increased nitrate and nitrite concentrations in saliva. The mean rise in salivary nitrate and nitrite concentration was $73 \mathrm{mg} / 1$ and $10 \mathrm{mg} / 1$, respectively, per 100 mg of ingested nitrate, which is in agreement with literature values $(4,5,27,30)$.

Approximately $18 \%$ of the salivary nitrate was reduced to nitrite (mean value at 2 hr after nitrate intake) during the test week, and 25\% of the salivary nitrate was reduced during the control weeks. Other studies have shown comparable results for nitrate reduction after a nitrate load $(4,27)$. On the other hand, no results are reported on nitrate reduction after a meal low in nitrate. Nitrate may be reduced more effectively when the amount of nitrate in saliva is low (31), leading to the relatively high level of reduction of nitrate observed during the control weeks.

As expected, nitrate intake at the ADI level resulted in a significant increase in mean 24-hr nitrate excretion in urine compared with the control weeks. In the test week, $88 \%$ and $75 \%$ of the nitrate dose was excreted in the urine. Previous reports have shown that upon nitrate ingestion, 65-70\% of the nitrate dose is excreted in the urine within $24 \mathrm{hr}$, while about $5 \%$ is converted to nitrite, and the rest is secreted in sweat $( \pm 10 \%)$, in colonic or vaginal secretions and in tears $(32,33)$.

Additionally, the urine samples were screened for nitrite content. Nitrite is not present in the urine of healthy individuals, but urinary tract infections (frequently present in young women) can lead to nitrite generation in the urinary tract. This implies the risk of nitrosamine formation in the urinary tract and confounding of the results. Nitrite was not detected in the urine samples of the female volunteers in this study.

Analyses of the urine samples for five volatile $\mathrm{N}$-nitrosamines showed that two volatile nitrosamines were present in the urine: NDMA and NPIP. Two other studies have been performed with human volunteers consuming test meals 
containing nitrate and fish, in which urine samples were analyzed for nitrosamine content $(28,34)$. Lakritz et al. (34) concluded that nitrosamine levels in urine, blood, and gastric juice were not significantly affected by ingestion of nitrosamine precursors. Maanen et al. (28) reported a significant increase in NDMA excretion in urine after consumption of food rich in nitrate and amines. Yamamoto et al. (35) measured nitrosamines only in blood, not in urine, and observed no effect after feeding eight individuals a Japanese diet rich in nitrate and amines. Additionally, Tricker et al. (36) reported that dimethylamine and piperidine were the most abundant (volatile) nitrosamine precursors present in gastric juice. They observed NDMA, NPIP, and N-nitrosopyrrolidine (NPYR) in the urine of spineinjured paraplegics (37), and the amounts of NDMA excreted are comparable with our results ( 650 versus 871 and $640 \mathrm{ng} / 24 \mathrm{hr}$ ), although they found higher NPIP levels (250 versus 86 and $94 \mathrm{ng} / 24 \mathrm{hr}$ ); we did not analyze the urine samples for NPYR. However, the nitrosamines excreted in urine of spine-injured paraplegics were predominantly formed in the urinary tract as a result of bacterial infections, while in our study the urinary nitrosamines were probably formed in the stomach. Thus, urinary nitrosamine levels in healthy volunteers consuming nitrosamine precursors in combination with nitrate intake at the ADI level are comparable with levels found in a group at high risk for nitrosamine formation. In the control weeks, mean NDMA excretion in urine was 287 and $383 \mathrm{ng} / 24 \mathrm{hr}$, and these results are in agreement with the $270 \mathrm{ng} / 24 \mathrm{hr}$ detected in the urine of an Egyptian control population (38).

Absolute levels of volatile nitrosamines formed in the stomach are probably much higher than the amounts excreted in urine. Spiegelhalder and coworkers $(39,40)$ showed that between 0.5 and $2.4 \%$ of an ingested NDMA dose was excreted unmetabolized in urine if ethanol was administered simultaneously. Without concomitant ethanol intake, less than $0.5 \%$ of the ingested NDMA was excreted unmetabolized in the urine. Assuming that $0.5 \%$ of the NDMA is excreted in urine, the volunteers in this study may have formed $174 \mu \mathrm{g}$ of NDMA per day or $2.9 \mu \mathrm{g}$ per $\mathrm{kg}$ body weight per day during days 1-3 of the test week. This exposure can be compared with the $10 \mu \mathrm{g}$ NDMA per kg per day that is carcinogenic in rats (41). The results clearly demonstrate that nitrate intake in combination with fish consumption resulted in an increase in NDMA excretion in urine of about $200 \%$. NPIP excretion, on the other hand, was not directly related to nitrate intake and the composition of the diet consumed during the study. However, a significant correlation was found between the cumulative nitrate excretion in urine and the cumulative NPIP excretion in urine, suggesting that NPIP formation, in contrast with NDMA formation, slowly increased after repeated high nitrate exposure; although subsequent metabolism seems to be comparable with NDMA metabolism (42-44). 
Vegetables contain vitamin $\mathrm{C}$ and other antioxidants that might prevent nitrosamine formation (45-47). In the present study, nitrosamine formation did increase during nitrate intake in combination with a fish meal, even though the volunteers consumed vegetables. These vegetables (cauliflower, peas, carrots, green beans) were low in nitrate and their mean vitamin $C$ content was approximately $17 \mathrm{mg}$ of vitamin $\mathrm{C}$ per $100 \mathrm{~g}$ vegetables (48). Thus, the amount of vitamin $C$ and other antioxidants in these vegetables appeared insufficient to prevent nitrosamine formation.

Results of linear regression analyses showed a good correlation between nitrate excretion in urine and NDMA excretion in urine. Additionally, correlations were found between the log of the salivary nitrate concentration and nitrate excretion in urine, between log salivary nitrate concentration and NDMA excretion in urine, and between log nitrite concentration in saliva and NDMA excretion in urine. The correlations between urinary nitrate and salivary nitrate and nitrite versus urinary NDMA support a relationship between nitrate intake and endogenous NDMA formation.

In conclusion, nitrate intake at the ADI level in combination with a fish meal containing nitrosatable precursors increased NDMA excretion in urine and therefore implies the risk of increased formation of carcinogenic N-nitrosamines. The results of this study suggest that the risk of formation of carcinogenic Nnitrosamines should be taken into account in the currently used ADI value for nitrate and in the drinking water guideline for nitrate.

\section{References}

1. WHO. Health hazards from nitrates in drinking water. Environmental Health Criteria 1. Copenhagen: World Health Organization Regional Office for Europe, 1985.

2. Van Maanen JMS, Van Dijk A, Mulder K, De Baets MH, Menheere PCA, Van der Heide D, Mertens PLJM, Kleinjans JCS. Consumption of drinking water with high nitrate levels causes hypertrophy of the thyroid. Toxicol Lett 72: 365-374 (1994).

3. Tenovuo J. The biochemistry of nitrates, nitrites, nitrosamines and other potential carcinogens in human saliva. Oral Pathol 15(6): 303-307 (1986).

4. Shapiro KB, Hotchkiss JH, Roe DA. Quantitative relationship between oral nitratereducing activity and the endogenous formation of $\mathrm{N}$-nitrosoamino acids in humans. Food Chem Toxicol 29(11): 751-755 (1991).

5. Spiegelhalder B, Eisenbrand G, Preussmann R. Influence of dietary nitrate on nitrite content of the human saliva: possible relevance to in vivo formation of N-nitroso compounds. Food Cosmet Toxicol 14: 545-548 (1976).

6. Bruning-Fann CS, Kaneene JB. The effects of nitrate, nitrite and N-nitroso compounds on human health: a review. Vet Human Toxicol 35(6): 521-538 (1993). 
7. Joint FAO-WHO Expert Committee on Food Additives (JECFA). Toxicological evaluation of certain food additioes with a reovew of general principles and of specifications. WHO Technical Report Series no. 539. Geneva. World I Jealth Organization, 1974.

8. Gangolli SD, Van den Brandt PA, Feron VJ, Janzowsky C, Koeman JII, Speijers GJA, Spiegelhalder B, Walker R, Wishnok JS. Nitrate, nitrite and N-nitroso compounds. Eur J Pharmacol Environ Toxicol 292: 1-38 (1994).

9. Pobel D, Riboli E, Cornée J, Hémon B, Guyader M. Nitrosamine, nitrate and nitrite in relation to gastric cancer: A case-control study in Marseille, France. Eur J Epidemiol 11: $67-73$ (1995)

10. Hill MJ. Mechanisms of gastric carcinogenesis. Eur J Cancer Prev 2 (suppl. 2): 73-78 (1993).

11. Bartsch H, Ohshima H, Shuker DEG, Pignatelli B, Calmels S. Exposure of humans to endogenous N-nitroso compounds: implications in cancer etiology. Mutat Res 238: 255-267 (1990).

12. Mirvish SS. Role of N-nitroso compounds (NOC) and N-nitrosation in etiology of gastric, esophageal, nasopharyngeal and bladder cancer and contribution to cancer of known exposures to NOC. Cancer Lett 93: 17-48 (1995).

13. Ward MH, Mark SD, Cantor KP, Weisenburger DD, Correa-Villaseñor A, Hoar Zahm S. Drinking water nitrate and the risk of non-Hodgkin's lymphoma. Epidemiology 7(5): 465-471 (1996).

14. Lin JK, Ho YS. Hepatotoxicity and hepatocarcinogenicity in rats fed squid with or without exogenous nitrite. Food Chem Toxicol 30(8): 695-702 (1992).

15. Caygill CPJ. Epidemiology relating N-nitroso compounds to human cancer. Eur J Cancer Prev 5: 125-130 (1996).

16. Boeing H. Epidemiological research in stomach cancer: progress over the last ten years. J Cancer Re's Clin Oncol 117: 133-143 (1991).

17. Forman D. Dietary exposure to $\mathrm{N}$-nitroso compounds and the risk of human cancer. Cancer Suro 6: 719-738 (1987).

18. Forman D, Al-Dabbagh S, Doll R. Nitrates, nitrites and gastric cancer in Great Britain. Nature 313: 620-625 (1985).

19. Ohshima H, Bartsch H. Quantitative estimation of endogenous nitrosation in humans by monitoring N-nitrosoproline excreted in the urine. Cancer Res 41: 36583662 (1981).

20. Knight TM, Leach S, Forman D, Vindigni C, Packer P, Venitt S, Minacci C, Lorenzini L, Tosi P, Frosini G, Marini M, Carnicelli N. N-nitrosoproline excretion in the presence and absence of gastric disease. Eur J Cancer 27(4): 456-461 (1991).

21. Zatonski W, Ohshima H, Przewozniak K, Drosik K, Mierzwinska J, Krygier M, Chmielarczyk W, Bartsch H. Urinary excretion of N-nitrosamino acids and nitrate by inhabitants of high- and low-risk areas for stomach cancer in Poland. Int / Cancer 44: 823-827 (1989).

22. Kamiyama S, Ohshima H, Shimada A, Saito N, Bourgade MC, Ziegler P, Bartsch H. Urinary excretion of N-nitrosamino acids and nitrate by inhabitants in high- and low-risk areas for stomach cancer in northern Japan. In: The relevance of $N$-nitroso compounds to human cancer: Exposures and mechanisms (Bartsch H, O'Neill IK, SchulteHerman R, eds). IARC Scientific Publications No. 84. Lyon: International Agency for Research on Cancer, 1987; 497-502. 
23. Van Maanen JMS, Welle IJ, Hageman G, Dallinga JW, Mertens PLJM, Kleinjans JCS. Nitrate contamination of drinking water: relationship with HPRT variant frequency in lymphocyte DNA and urinary excretion of N-nitrosamines. Environ Health Perspect 104: 522-528 (1996).

24. Groenen PJ, Luten JB, Dhont JH, Cock-Bethbeder MW de, Prins LA, Vreeken JW. Formation of volatile N-nitrosamines from food products, especially fish, under simulated gastric conditions. In: N-Nitroso compounds: Occurrence and Biological Effects (Bartsch H, O'Neill IK, Castegnaro M, Okada M, eds). IARC Scientific Publications No. 41. Lyon: International Agency for Research on Cancer, 1982; 99-112.

25. Singer GM, Lijinsky W. Naturally occuring nitrosatable compounds. I. Secondary amines in foodstuffs. J Agric Food Chem 24(3): 550-553 (1976).

26. Beutler $\mathrm{HO}$ von, Wurst B, Fischer S. Eine neue methode zur enzymatischen bestimmung von nitrat in lebensmitteln. Deut Lebensm-Rundsch 82: 283-289 (1986).

27. Van Maanen JM, Van Geel AA, Kleinjans, JC. Modulation of nitrate-nitrite conversion in the oral cavity. Cancer Detect Prev 20(6): 590-596 (1996).

28. Van Maanen JMS, Pachen DMFA, Dallinga JW, Kleinjans JCS. Formation of nitrosamines during consumption of nitrate- and amine-rich food and the influence of the use of mouthwashes. Cancer Detect Prev 22(3): 204-212 (1998).

29. Cicchetti DV. Multiple comparison methods: establishing guidelines for their valid application in neuropsychological research. J Clin Exp Neuropsychol 16(1): 155-161 (1994).

30. Granli T, Dahl R, Brodin P, Bøckman OC. Nitrate and nitrite concentrations in human saliva: variations with salivary flow-rate. Food Chem Toxic 27(10): 675-680 (1989).

31. Tannenbaum SR, Weisman M, Fett $\mathrm{D}$. The effect of nitrate intake on nitrite formation in human saliva. Food Cosmet Toxicol 14: 549-552 (1976).

32. Bartholomew B, Hill MJ. The pharmacology of dietary nitrate and the origin of urinary nitrate. Food Chem Toxicol 22(10): 789-795 (1984).

33. Leach SA, Packer PJ, Hill MJ. Salivary and urinary nitrate as measures of nitrate intake. Biochem Soc Trans 15: 911-912 (1987).

34. Lakritz L, Gates RA, Gugger AM, Wasserman AE. Nitrosamine levels in human blood, urine and gastric aspirate following ingestion of foods containing potential nitrosamine precursors or preformed nitrosamines. Food Chem Toxicol 20: 455-459 (1982).

35. Yamamoto M, Yamada T, Tanimura A. Volatile nitrosamines in human blood before and after ingestion of a meal containing high concentrations of nitrate and secondary amines. Food Cosmet Toxicol 18: 297-299 (1980).

36. Tricker AR, Pfundstein B, Kälble $T$, Preussmann R. Secondary amine precursors to nitrosamines in human saliva, gastric juice, blood, urine and faeces. Carcinogenesis 13(4): 563-568 (1992).

37. Tricker AR, Stickler DJ, Chawla JC, Preussmann R. Increased urinary nitrosamine excretion in paraplegic patients. Carcinogenesis 12(5): 943-946 (1991).

38. Tricker AR, Mostafa MH, Spiegelhalder B, Preussmann R. Urinary excretion of nitrate, nitrite and $\mathrm{N}$-nitroso compounds in Schistosomiasis and bilharzia bladder cancer patients. Carcinogenesis 10(3): 547-552 (1989).

39. Spiegelhalder B, Eisenbrand G, Preussmann R. Urinary excretion of N-nitrosamines in rats and humans. In: N-Nitroso Compounds: Occurrence and Biological Effects 
(Bartsch H, Castegnaro M, O'Neill I, Okada M, eds). IARC Scientific Publications Xóo. 41. Lyon: International Agency for Research on Cancer, 1982; 443-449.

40. Spiegelhalder B, Preussmann R. In vivo nitrosation of amidopyrine in humans: use of 'ethanol effect' for biological monitoring of $\mathrm{N}$-nitrosodimcthylamine in urine. Carcinogenesis 6(4): 545-548 (1985).

41. Peto R, Gray R, Brantom P, Grasso P. Nitrosamine carcinogenesis in 5120 rodents: chronic administration of sixteen different concentrations of NDEA, NDMA, NPYR and NPIP in the water of 4440 inbred rats, with parallel studies on NDEA alone of the effect of age of starting (3,6 or 20 weeks) and of species (rats, mice or hamsters). In: N-Nitroso Compounds: Occurrence, Biological Effects and Relevance to Human Cancer (O'Neill I, Borstel RC von, Miller CT, Long J, Bartsch H). IARC Scientific Publications No. 57. Lyon: International Agency for Research on Cancer, 1984; 627-665.

42. Guttenplan JB. Structure-activity relationships in metabolism and mutagenicities of $N$-nitrosamines. In: The releoance of $N$-nitroso compounds to human cancer. Exposures and mechanisms (Bartsch H, O'Neill I, Schulte-Herman R, eds). IARC Scientific Publications No. 84. Lyon: International Agency for Research on Cancer, 1987; 129131.

43. Singer GM, Macintosh WA. Urinary metabolites of some alicyclic nitrosamines. In: N-Nitroso Compounds: Occurrence, Biological Effects and Relevance to Human Cancer (ONeill I, Borstel RC von, Miller CT, Long J, Bartsch H). IARC Scientific Publications No. 57. Lyon: International Agency for Research on Cancer, 1984; 459-463.

44. Ayrton AD, Smith JN, Ioannides C. Bioactivation of N-nitrosopiperidine to mutagens: role of hepatic cytochrome $\mathrm{P}-450$ proteins and contribution of cytosolic fraction. Carcinogene'sis 8(11): 1691-1695 (1987).

45. Bartsch $\mathrm{H}$, Ohshima $\mathrm{H}$, Pignatelli B. Inhibitors of endogenous nitrosation. Mechanisms and implications in human cancer prevention. Mutat Res 202: 307-324 (1988).

46. Tannenbaum SR, Wishnok JS, Leaf CD. Inhibition of nitrosamine formation by ascorbic acid. Am J Clin Nutr 53: 247S-250S (1991).

47. Schorah CJ, Sobala GM, Sanderson M, Collis N, Primrose JN. Gastric juice ascorbic acid: effects of disease and implications for gastric carcinogenesis. Am J Clin Nutr 53 : 287S-293S (1991).

48. NEVO. Dutch food composition datrbase. Zeist: NEVO Foundation, 1996. 


\section{Chapter 4}

\section{Effect of ascorbic acid and green tea on endogenous formation of $\mathrm{N}$-nitrosodimethylamine and $\mathrm{N}$-nitrosopiperidine in humans}

I.T.M. Vermeer

E.J.C. Moonen

J.W. Dallinga

J.C.S. Kleinjans

J.M.S. van Maanen

Mutation Reserarch 428: 353-361 (1999)

Department of Health Risk Analysis and Toxicology, Maastricht University, P.O. Box 616, 6200 MD Maastricht, The Netherlands 


\begin{abstract}
Many constituents present in the human diet may inhibit endogenous formation of N-nitroso compounds (NOC). Studies with human volunteers showed inhibiting effects of intake of ascorbic acid and green tea consumption on nitrosation using the $\mathrm{N}$-nitrosoproline test. The aim of the present study was to evaluate the effects of ascorbic acid and green tea on urinary excretion of carcinogenic N-nitrosodimethylamine (NDMA) and N-nitrosopiperidine (NPIP) in humans. Twenty-five healthy female volunteers consumed a fish meal rich in amines as nitrosatable precursors in combination with intake of nitrate-containing drinking water at the Acceptable Daily Intake level during 7 consecutive days. During 1 week before and after nitrate intake a diet low in nitrate was consumed. Using the same protocol, the effect of two different doses of ascorbic acid (250 $\mathrm{mg}$ and $1 \mathrm{~g}$ per day) and two different doses of green tea ( $2 \mathrm{~g}$ and $4 \mathrm{~g}$ per day) on formation of NDMA and NPIP was studied. Mean nitrate excretion in urine significantly increased from control $(76 \pm 24)$ to $167 \pm 25 \mathrm{mg} / 24 \mathrm{~h}$. Intake of nitrate and fish resulted in a significant increase in mean urinary excretion of NDMA compared with the control weeks: $871 \pm 430$ and $640 \pm 277 \mathrm{ng} / 24 \mathrm{~h}$ during days 13 and 4-7, respectively, compared with $385 \pm 196 \mathrm{ng} / 24 \mathrm{~h}(\mathrm{p}<0.0002)$. Excretion of NPIP in urine was not related to nitrate intake and composition of the diet. Intake of $250 \mathrm{mg}$ and $1 \mathrm{~g}$ of ascorbic acid per day resulted in a significant decrease in urinary NDMA excretion during days 4-7 ( $\mathrm{p}=0.0001)$, but not during days 1-3. Also, consumption of 4 cups of green tea per day $(2 \mathrm{~g})$ significantly decreased excretion of NDMA during days 4-7 ( $\mathrm{p}=0.0035$ ), but not during days 1-3. Surprisingly, consumption of 8 cups of green tea per day $(4 \mathrm{~g})$ significantly increased NDMA excretion during days 4-7 ( $p=0.0001$ ), again not during days 13. This increase is probably a result of catalytic effects of tea polyphenols on nitrosation, or of another, yet unknown, mechanism. These results suggest that intake of ascorbic acid and moderate consumption of green tea can reduce endogenous NDMA formation.
\end{abstract}




\section{Introduction}

Human exposure to endogenously formed N-nitroso compounds (NOC) has been related to an increased risk of gastric, esophageal, nasopharyngeal, and bladder cancer (1). Endogenous formation of NOC occurs predominantly in the stomach, and can also occur at various other sites in the body. Many dietary constituents, such as vitamins $C$ and $E$, polyphenols and complex mixtures as fruit juices, may inhibit the nitrosation reaction (2).

Epidemiological studies showed a protective effect of vitamin $C$ on gastric cancer; all seven studies evaluating the effect of vitamin $C$ on cancer of the stomach, found a statistically significant protection of approximately twofold (3). Most studies with human volunteers concerning the effect of vitamin $C$ on nitrosation used the NPRO ( $\mathrm{N}$-nitrosoproline) test, as reviewed by Mirvish $(4,5)$. NPRO is a noncarcinogenic compound, formed in the stomach by nitrosation of proline, and is quantitatively excreted in urine without being metabolized. Doses of ascorbic acid from as low as $9 \mathrm{mg}$ to $1 \mathrm{~g}$ per day were reported to inhibit NPRO formation to an extent of $20-100 \%$, respectively $(4,6)$. These inhibitions were calculated on the basis of the 'net' NPRO excretion: the mean NPRO excretion after intake of nitrate and proline, minus the basal excretion level of NPRO, after proline alone was administered without nitrate. Maximum inhibition of NPRO excretion occurred when ascorbic acid was supplemented concurrently with proline and a meal, compared with taking ascorbic acid $0.5-6 \mathrm{~h}$ before, or $0.5-2 \mathrm{~h}$ after proline and the meal (7).

Another constituent of the human diet that has been reported to inhibit nitrosation, is green tea. Results from epidemiology studies concerning the relationship between tea consumption and various human cancers (bladder and urinary tract, breast, colon and rectum, esophagus, kidney, liver, lung, nasopharynx, pancreas, stomach and uterus) are inconclusive (8-10). In contrast, in vivo studies with experimental animals clearly demonstrate significant chemopreventive effects of green and black tea components against tumorigenesis in several organs, such as lung and forestomach, and against each stage of skin carcinogenesis $(9,11)$. The chemopreventive effect of green tea is attributed to the antioxidant properties of polyphenols present in tea (about 30-40\% of the dry weight) $(11,12)$. Most of the polyphenols are catechins, and (-)-epigallocatechin gallate (EGCG) is the major catechin in green tea. During the manufacturing of black tea, 90-95\% of the catechins undergo oxidative polymerization, reducing the antioxidant potency of black tea compared with green tea $(13,14)$.

In vitro studies with green tea showed a strong inhibitory effect on the formation of NOC, after incubation of nitrite with salt-preserved fish extracts and green tea $(15,16)$. Wu et al. (12) demonstrated in vitro an inhibitory effect of high concentrations of green tea on formation of $\mathrm{N}$-nitrosomorpholine, while low 
concentrations of tea promoted N-nitrosation. A limited number of studies has been performed with human volunteers, using the NPRO test to examine the effect of green tea on $\mathrm{N}$-nitrosation $(12,16,17)$. The results showed that green tea inhibited NPRO formation and that $3-5 \mathrm{~g}$ of green tea per day could completely block NPRO formation (12).

These possibly inhibitory effects of green tea and of ascorbic acid have not been studied for other NOC in humans, except for the effect of ascorbic acid on Nnitrosothiazolidine-4-carboxylic acid excretion $(7,18)$. NOC are an extensive group of compounds and NPRO is used as a model compound because it is noncarcinogenic and not metabolized in the human body. In the present study, however, we were interested in the effects of ascorbic acid and green tea on the formation of carcinogenic volatile N-nitrosamines.

The objectives, therefore, were to evaluate the effects of ascorbic acid and green tea on the formation of the carcinogenic N-nitrosodimethylamine (NDMA) and N-nitrosopiperidine (NPIP) in humans. Volunteers consumed a fish meal rich in nitrosatable precursors and received a nitrate dose in water, a protocol which has previously been shown to lead to increased NDMA formation (19); the effects of two simultaneous doses of ascorbic acid and green tea were assessed. Urine was collected to determine excretion levels of NDMA and NPIP.

\section{Materials and methods}

\section{Study population and protocol}

Twenty-five healthy non-smoking female volunteers participated in this study. The study was approved by the medical ethical committee of the University of Maastricht. The volunteers signed an informed consent, and answered to a questionnaire on food consumption and lifestyle habits. The participants used no medicine or vitamin preparations prior to or during the study. The mean weight of the subjects ( \pm S.D.) was $60 \pm 6 \mathrm{~kg}$ (range $48-75 \mathrm{~kg}$ ) and the mean age was $23 \pm 7$ years (range $18-46$ years).

The study started with a control week in which the subjects refrained from consumption of high nitrate-containing food items in order to determine the background level of urinary excretion of NDMA. At day 7 during the control week, 24-h urine was collected. A $100 \mathrm{ml}$ sample was taken and stored at $-20^{\circ} \mathrm{C}$. Subsequently, during the experimental week, the participants received a total daily nitrate dose of $220 \mathrm{mg}$ in combination with a meal low in nitrate and containing fish (cod, salmon, shrimp, pollack) as a source of nitrosatable precursors. The nitrate dose of $220 \mathrm{mg}$ has been chosen since this is the Acceptable Daily Intake level for a person of $60 \mathrm{~kg}$ (the mean weight of the participants). Every day of each experimental week, 24-h urine was collected. 


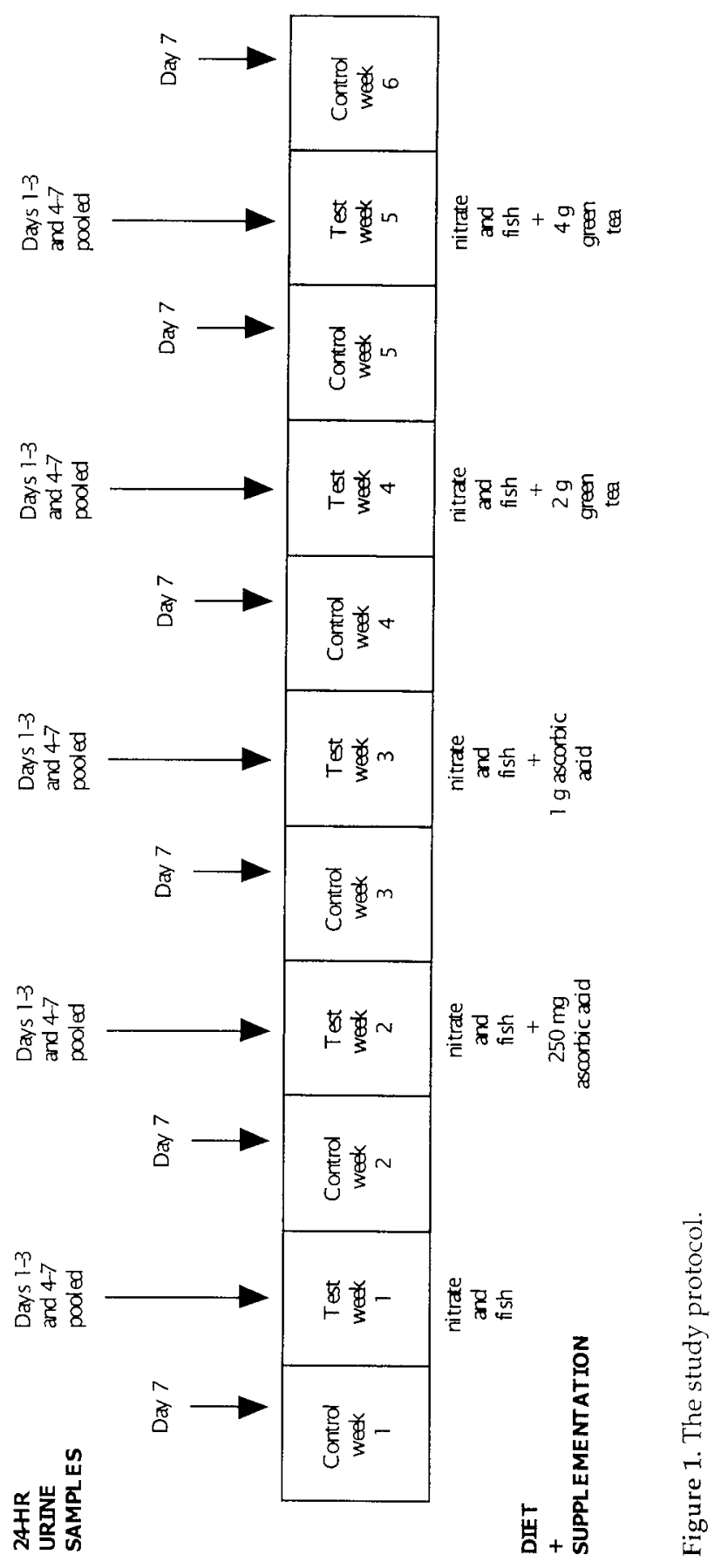


The urine samples of days 1-3 were pooled and the urine samples of days 4-7 were pooled. A $100-\mathrm{ml}$ aliquot of each pooled sample was stored at $-200^{\circ} \mathrm{C}$. This protocol has previously been described in more detail (19).

This protocol was repeated to study the effect of daily intake of two different doses of ascorbic acid and consumption of two different amounts of green tea on formation of volatile $\mathrm{N}$-nitrosamines as outlined in Figure 1.

The ascorbic acid (in tablets of $250 \mathrm{mg}$, Orthica bv., Weesp, The Netherlands) was supplemented simultaneously with the nitrate dose and the fish meal. The green tea (lyophilized tea solids, TJ Lipton Inc, USA) was dissolved in boiling water $(0.5 \mathrm{~g}$ in $100 \mathrm{ml})$ and consumed during the day: 4 cups (2 g) of tea per day in test week 4 , and 8 cups $(4 \mathrm{~g})$ of tea per day in test week 5 . One or two cups of the tea were consumed in the morning, during the meal at the university, in the afternoon, and in the evening. Based on previous reports $(4,6,12), 1 \mathrm{~g}$ of ascorbic acid and $4 \mathrm{~g}$ of green tea were expected to result in maximum inhibition of nitrosamine formation, and $250 \mathrm{mg}$ of ascorbid acid and $2 \mathrm{~g}$ of green tea to result in partial inhibition.

\section{Analysis of nitrate and nitrite in urine}

24-h urine was collected in 2 liter containers supplemented with $10 \mathrm{~g}$ $\mathrm{NaOH}$ pellets. The volume of the urine was recorded and $100 \mathrm{ml}$ samples were stored at $-20^{\circ} \mathrm{C}$ until analysis. $1 \mathrm{ml}$ of urine was centrifuged for $10 \mathrm{~min}$ at $12,000 \mathrm{~g}$. The nitrate level was determined spectrophotometrically according to a method from Boehringer (Boehringer Mannheim Kit no 905658), using $50 \mu \mathrm{l}$ of the supernatant (20). The amount of nitrate excreted in urine was calculated by multiplying the urinary nitrate concentration with the volume of the 24-h urine. Urine samples were screened for nitrite content as an indicator of urinary tract infections, using nitrite test strips (Merckoquant nitrit-test; Merck, Germany). Nitrite was not detected in the samples.

\section{Analysis of volatile N-nitrosamines in urine and green tea}

The urine samples of control week 1 and 2, and of experimental week 1 were screened for 5 volatile $\mathrm{N}$-nitrosamines: N-nitrosodimethylamine (NDMA), $\mathrm{N}$-nitrosomethylethylamine (NMEA), N-nitrosodiethylamine (NDEA), Nnitrosopiperidine (NPIP), and N-nitrosomorpholine (NMOR), by gas chromatography-mass spectrometry (GC-MS). It appeared that only NDMA and NPIP were present in the samples and therefore the remaining urine samples were only screened for NDMA and NPIP.

The GC-MS method was previously described in detail (19). It can be summarized as follows: $20 \mathrm{ml}$ of urine were extracted with $1 \mathrm{ml}$ of dichloromethane. $0.5 \mu 1$ of the dichloromethane solution was injected into the GCMS system, consisting of a gas chromatograph (Hewlett-Packard, Avondale, 
Pennsylvania) and a Jeol SX102A mass spectrometer (Jeol Ltd., Tokyo). The column used was a WCOT fused silica column (Chrompack, New Jersey), and helium was used as the carrier gas $(1 \mathrm{ml} / \mathrm{min})$. The mass spectrometer generated ions by electron ionization at $70 \mathrm{eV}$. The molecular ions $\left(\mathrm{M}^{+}\right.$.) were detected using high-resolution, single-ion monitoring (HR-SIM). The detection limit for the separate $\mathrm{N}$-nitrosamines was $1 \mathrm{pg} / \mu \mathrm{l}$ of dichloromethane solution, corresponding to $50 \mathrm{pg} / \mathrm{ml}$ of urine. Using the same method, the green tea was also screened for NDMA and NPIP.

\section{Statistical methods}

Results are expressed as mean \pm S.D. Statistical comparisons of the data on urinary NDMA excretion were performed by the non-parametric Wilcoxon signed-rank test. Multiple comparisons were made within one set of data, thereby increasing the chance of a type I error. Therefore, alpha was adjusted to $0.004(0.05$ divided by the number of comparisons) and a p-value $<0.004$ was considered statistically significant (21).

\section{Results}

Nitrate excretion in urine during the experimental weeks was significantly increased compared with the control weeks (Wilcoxon, $\mathrm{p}=0.0001$ ). The mean urinary nitrate excretion ( \pm S.D.) during the six control weeks and the five test weeks was $76 \pm 24$ and $167 \pm 25 \mathrm{mg} / 24 \mathrm{~h}$, respectively. There was some fluctuation in the nitrate excretion and this is presented in Table 1.

Urinary excretions of NDMA and NPIP were determined by GC-MS. The level of NDMA excretion was comparable for the 6 control weeks and therefore the mean urinary excretion of NDMA during the 6 control weeks is presented for each individual. Figure 2 shows the urinary excretion of NDMA during the experimental weeks and the control weeks. A nitrate dose of $220 \mathrm{mg}$ in combination with a fish meal resulted in a significant increase in NDMA excretion compared with the mean NDMA level in urine during the control weeks (Wilcoxon, p < 0.0002); mean NDMA excretions are presented in Table 2.

In test weeks 2 and 3 the effect of ascorbic acid intake on formation of NDMA was studied. The average NDMA excretion during test weeks 2 and 3 was $576 \pm 210$ and $608 \pm 300 \mathrm{ng} / 24 \mathrm{~h}$, respectively, compared with $756 \pm 269 \mathrm{ng} / 24 \mathrm{~h}$ during test week 1. Overall, this indicates a decreased NDMA excretion after intake of $250 \mathrm{mg}(\mathrm{p}=0.0027)$ and $1 \mathrm{~g}(\mathrm{p}=0.0061)$ of ascorbic acid. More in detail, in test week 2, the ascorbic acid supplement of $250 \mathrm{mg}$ resulted however in a comparable level of NDMA excretion during days 1-3 compared with test week 1 days 1-3. During days 4-7, urinary NDMA excretion significantly decreased 
compared to test week 1 days $4-7$ (Wilcoxon, $\mathrm{p}=0.0001$ ), and also compared to the control weeks $(\mathrm{p}=0.0032)$.

Table 1. Nitrate excretion in urine $(\mathrm{mg} / 24 \mathrm{~h})$ during the study protocol

\begin{tabular}{llll}
\hline $\begin{array}{l}\text { Nitrate excretion in urine } \\
(\mathrm{mg} / 24 \mathrm{~h}) \pm \text { S.D. } \\
\text { during the control weeks }\end{array}$ & $\begin{array}{l}\text { Nitrate excretion in urine } \\
(\mathrm{mg} / 24 \mathrm{~h}) \pm \text { S.D. } \\
\text { during the test weeks }\end{array}$ \\
\hline CW1 & $76 \pm 42$ & TW1 & $180 \pm 36$ \\
CW2 & $77 \pm 41$ & TW2 & $176 \pm 47$ \\
CW3 & $68 \pm 39$ & TW3 & $160 \pm 22$ \\
CW4 & $79 \pm 41$ & TW4 & $150 \pm 25$ \\
CW5 & $71 \pm 26$ & TW5 & $170 \pm 33$ \\
CW6 & $86 \pm 43$ & & \\
& $76 \pm 24$ & Mean TW & $167^{*} 25$ \\
Mean CW & & & \\
\hline
\end{tabular}

* Significantly increased compared with the mean nitrate excretion during the 6 control weeks (Wilcoxon, $\mathrm{p}=0.0001$ ).

The ascorbic acid supplementation of $1 \mathrm{~g}$ in test week 3 gave the same results as the supplementation of $250 \mathrm{mg}$ in test week 2; no additional effect of the higher ascorbic acid dose was observed. There was no significant difference between the level of NDMA in urine during days 1-3 in test week 3 and days 1-3 in test week 1. During days 4-7, urinary NDMA excretion significantly decreased compared with test week 1 days 4-7 ( $p=0.0001)$, and was not significantly different from the control weeks.

In test week 4 , per day four cups of green tea ( $2 \mathrm{~g}$ of tea) were consumed. The average NDMA excretion during the week was $843 \pm 303 \mathrm{ng} / 24 \mathrm{~h}$; this was not significantly different compared with test week 1 . During days 1-3 there was a nonsignificant increase in NDMA excretion compared with days 1-3 in test week 1. During days 4-7, the level of NDMA excretion significantly decreased compared with test week 1 days 4-7 $(\mathrm{p}=0.0035)$, to a level comparable with the control weeks.

In test week 5, drinking eight cups of green tea per day ( $4 \mathrm{~g}$ of tea) resulted in an average NDMA excretion of $1541 \pm 850 \mathrm{ng} / 24 \mathrm{~h}$; a significant increase compared to test week 1 ( $p=0.0001)$. A very high interindividual variation was observed. There was no significant difference in NDMA excretion between days 

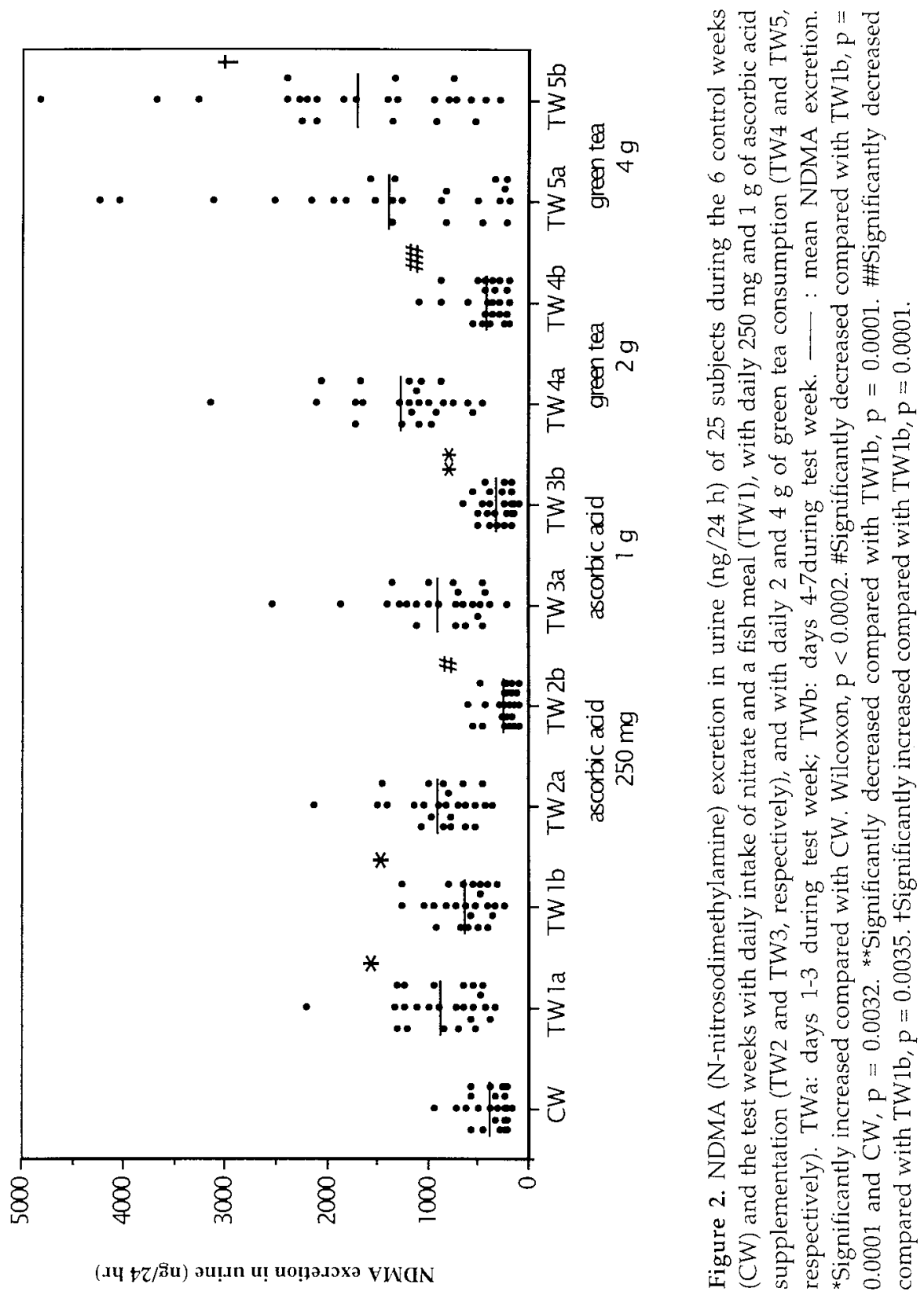
1-3 in test week 5 and days 1-3 in test week 1. During days 4-7, a significant increase in NDMA excretion was observed compared with test week 1 days 4-7 ( $p$ $=0.0001)$.

Since there was some fluctuation in the urinary nitrate excretion during the different test weeks, we also calculated the levels of urinary NDMA excretions, corrected for nitrate excretion. This had no influence on the outcome of the statistical evaluation.

Table 2. Mean urinary excretion of NDMA and NPIP (ng/24h) during the study protocol

\begin{tabular}{lccc}
\hline & $\begin{array}{l}\text { NDMA excretion in urine } \\
(\mathrm{ng} / 24 \mathrm{~h}) \pm \text { S.D. }\end{array}$ & $\begin{array}{l}\text { NPIP excretion in urine } \\
(\mathrm{ng} / 24 \mathrm{~h}) \pm \text { S.D. }\end{array}$ \\
\hline CW & 385 & \pm 196 & $117 \pm 75$ \\
TW1a & $871^{*} \pm 430$ & $86 \pm 49$ \\
TW1b & $640^{*} \pm 277$ & $94 \pm 57$ \\
TW2a & 898 & \pm 402 & $129 \pm 105$ \\
TW2b & $254^{\#} \pm 144$ & $58 \pm 40$ \\
TW3a & 905 & \pm 520 & $88 \pm 59$ \\
TW3b & $312^{* *} \pm 152$ & $147 \pm 130$ \\
TW4a & 1261 & \pm 584 & $100 \pm 91$ \\
TW4b & $424^{\# \#} \pm 226$ & $67 \pm 49$ \\
TW5a & 1386 & \pm 1160 & $222 \pm 273$ \\
TW5b & $1701^{+} \pm 1099$ & $225 \pm 198$
\end{tabular}

* Significantly increased compared with CW. Wilcoxon, $p<0.0002$

\# Significantly decreased compared with TW $1 \mathrm{~b}, \mathrm{p}=0.0001$ and $\mathrm{CW}, \mathrm{p}=0.0032$

** Significantly decreased compared with TW1b, $p=0.0001$

\# Significantly decreased compared with TW1b, $p=0.0035$

$+\quad$ Significantly increased compared with TW1b, $p=0.0001$

Mean urinary NPIP excretions fluctuated during the study period as presented in Table 2. Strikingly, NPIP excretion in test week 5 appears to be high compared with the other test weeks, however, NPIP excretion in control week 6 was also $213 \pm 280 \mathrm{ng} / 24 \mathrm{~h}$.

No NDMA and NPIP were detected in the green tea samples. 


\section{Discussion}

Nitrosamine formation in the acidic stomach can take place when both nitrite and secondary amines are present. Nitrite is readily protonated to nitrous acid $\left(\mathrm{HNO}_{2}\right)$ and 2 molecules of nitrous acid form nitrogen trioxide $\left(\mathrm{N}_{2} \mathrm{O}_{3}\right)$, which is the actual nitrosating species that reacts with unprotonated amines to form nitrosamines (2). Ascorbic acid inhibits nitrosation, because it reacts faster than the amine with the nitrosating agent. Ascorbic acid reduces nitrous acid to nitric oxide (NO), which is not directly a nitrosating agent, and is itself oxidized to dehydroascorbic acid $(2,22)$. Tea polyphenols also inhibit nitrosation by competing with secundary amines for nitrosating species; the phenolic groups are then oxidized to quinone moieties (2).

In the present study, intake of nitrate in combination with a fish meal resulted in a significant increase in nitrate and NDMA excretions in urine, compared with the control weeks with a low nitrate intake and no fish consumption. As shown in Table 2, excretion of NPIP was not related to nitrate intake, composition of the diet, and intake of ascorbic acid and green tea, as was concluded before (19).

The mean NDMA excretion during the different test weeks decreased after intake of $250 \mathrm{mg}$ and $1 \mathrm{~g}$ of ascorbic acid, respectively, did not change after drinking 4 cups of green tea and increased after consumption of 8 cups of green tea per day. However, we measured NDMA excretion during days 1-3 and days 4-7 in the 5 test weeks and these results showed a difference between days 1-3 and days 4-7. Obviously, in contrast to the studies evaluating the effect of ascorbic acid and green tea on formation of NPRO, intake of ascorbic acid and green tea changed NDMA excretion only after a few days. In test week 1, intake of nitrate in combination with a fish meal resulted in an increased NDMA excretion. NDMA excretion during days 4-7 was somewhat lower than during days 1-3, suggesting a change in activity of metabolizing enzymes (adaptive respons). This was also observed for the metabolism of Polycyclic Aromatic Hydrocarbons (PAH), during 5 days consumption of grilled meat (23). Strikingly, this tendency was repeated during the other test weeks, with exception of test week 5 (consumption of 8 cups of green tea), while every test week was alternated with a control week.

An ascorbic acid supplement of $250 \mathrm{mg}$ per day decreased NDMA excretion during the second part of the supplementation period, to a level lower than during the control weeks. Nitrosation of dimethylamine by nitrosating species arised from the nitrate intake was completely blocked. However, there was still NDMA present in urine, probably partly derived from preformed NDMA in the diet, and partly from nitrosation of dimethylamine by other nitrosating agents, or in parts of the body that were not reached by ascorbic acid. This was also observed in studies using NPRO excretion as an end point 
$(6,18,24,25)$. Wagner et al. (24) used $\left[{ }^{15} \mathrm{~N}\right]$ nitrate as a tracer to study excretion of NPRO in urine. They demonstrated that urinary NPRO excretion resulting from endogenous synthesis was not totally derived from ingested nitrate. In in vitro studies, a 2:1 molar ratio of ascorbic acid to nitrite was sufficient to completely block formation of NPRO (6). However, supplementing ascorbic acid to humans more than 10 times the amount required to block nitrosation in vitro, did not completely reduce the urinary excretion of NPRO to baseline levels (6). Also, Garland et al (26) reported no effect of vitamin $C$ supplements on the basal urinary excretion of NPRO and NDMA. These observations and our results indicate that nitrosamine formation in humans is more complex than in vitro studies have shown and that ascorbic acid can strongly inhibit, but not completely block endogenous nitrosation.

Surprisingly, ascorbic acid did not decrease NDMA excretion during days 1-3. Studies have shown that supplementing ascorbic acid concurrently with proline intake and a meal gave the maximum inhibition of endogenous NPRO formation during the day that ascorbic acid was supplemented $(4,7)$. This was probably a result of a maximum ascorbic acid:nitrite ratio in the stomach (7). However, intake of ascorbic acid $5 \mathrm{~h}$ before proline intake also significantly decreased NPRO formation (7). This was due to active secretion of ascorbic acid from the blood into the stomach (27). Supplementing subjects with ascorbic acid increased plasma ascorbic acid levels and ascorbic content of the stomach to a maximum $(28,29)$. It could be suggested that after intake of $250 \mathrm{mg}$ of ascorbic acid active secretion of ascorbic acid into the stomach was an important contributing factor resulting in maximum inhibition of NDMA formation after a few days. However, this should have resulted in a decrease in NDMA formation during days 1-3 after intake of $1 \mathrm{~g}$ of ascorbic acid.

Supplementing the volunteers with $1 \mathrm{~g}$ of ascorbic acid decreased NDMA excretion to a level comparable with the control weeks. Obviously, the dose of 250 mg of ascorbic acid was sufficient to reach the maximum inhibition of NDMA formation that was possible and increasing the dose 4 times did not have an additional effect. Up till now, the absence of an inhibiting effect of ascorbic acid on NDMA formation during days 1-3 cannot be explained.

Daily consumption of 4 cups of green tea (2 grams) decreased NDMA excretion during days 4-7 of test week 4, to a level comparable with the control weeks. Wu et al. (12) demonstrated that $1 \mathrm{~g}$ of green tea per day partially blocked endogenous synthesis of NPRO and 3-5 g decreased NPRO formation to baseline levels within $24 \mathrm{~h}$ after tea consumption. Two other studies observed an immediate inhibiting effect of green tea on NPRO formation, using $4.65 \mathrm{~g}$ extracted solids from green tea (decreasing NPRO excretion to levels lower than the baseline), and 2 cups of green tea per day, respectively $(16,17)$. 
Again, no decrease in NDMA excretion was observed during days $1-3$. The authors of a recent study with human volunteers taking $1.5,3$, and $4.5 \mathrm{~g}$ of green tea concluded that it is not likely that tea catechins accumulate in the body (30). Our result can probably not be explained by accumulation of tea polyphenols in the stomach.

Consumption of 8 cups of green tea in test week 5 significantly increased NDMA excretion during days 4-7. Since there was no NDMA present in the green tea, the volunteers did not have an increased intake of preformed NDMA. In vitro studies have shown that some phenolic compounds can form C-nitroso derivates which can act as powerful nitrosating agents and catalyse nitrosation, depending on $\mathrm{pH}$ and relative concentrations of the reactants $(31,32,33)$. This catalytic effect was demonstrated for NPRO formation (after an incubation of $15 \mathrm{~min}$ ) (32), Nnitrosopyrrolidine (NPYR), N-nitroso-N-methylaniline (incubation of $1 \mathrm{~h}$ ) and $\mathrm{N}$ nitrosomorpholine (NMOR, after $30 \mathrm{~min}$ of incubation) (12,33), and for NDMA, N-nitrosodiethylamine (NDEA), NPIP and NPYR (30 min incubation) (31), after in vitro incubation of nitrite, the different amines and phenolic compounds. The catalytic effect of green tea extract was strongest for NDMA, compared with NDEA, NPIP and NPYR (31). However, this was observed for low concentrations of phenolic compounds, and higher concentrations inhibited N-nitrosamine formation, as has been discussed by $W u$ et al. (12): phenolic compounds can catalyse nitrosation when the molar ratio phenolic compounds:nitrite is $<1$, and inhibiting effects can be expected when this ratio is $>1$.

In the present study, the ratio polyphenols:nitrite is $>1$, assuming that $5 \%$ of the ingested nitrate is converted in the oral cavity to nitrite and reingested totally (34). The situation in vivo might be different than in vitro, resulting in a catalytic effect of high intake of green tea, or the increased formation of NDMA is the result of another, yet unknown, mechanism.

In conclusion, ascorbic acid supplementation decreased excretion of NDMA, as was already shown for NPRO. A daily dose of $250 \mathrm{mg}$ was sufficient to inhibit NDMA excretion to the maximum extent. Consumption of 4 cups of green tea ( $2 \mathrm{~g}$ of tea) significantly decreased NDMA excretion during the second part of the consumption period. However, drinking 8 cups of green tea implies the risk of increased formation of carcinogenic NDMA, via a yet unknown mechanism.

\section{Acknowledgements}

This study was supported by the Netherlands Prevention Fund (grant 28-2844). Furthermore, we thank Unilever (Vlaardingen, The Netherlands) for providing the green tea, Orthica B.V. (Weesp, The Netherlands) for providing the ascorbic acid, and the 25 volunteers who participated in this study. 


\section{References}

1. Mirvish SS. Role of N-nitroso compounds (NOC) and N-nitrosation in etiology of gastric, esophageal, nasopharyngeal and bladder cancer and contribution to cancer of known exposures to NOC. Cancer Lett 93: 17-48 (1995).

2. Bartsch H, Ohshima H, Pignatelli B. Inhibitors of endogenous nitrosation. Mechanisms and implications in human cancer prevention. Mutat Res 202: 307-324 (1988).

3. Block G. Vitamin C and cancer prevention: the epidemiologic evidence. Am I Clin Nutr 53: 270S-282S (1991).

4. Mirvish SS. Experimental evidence for inhibition of $\mathrm{N}$-nitroso compound formation as a factor in the negative correlation between vitamin $\mathrm{C}$ consumption and the incidence of certain cancers. Cancer Res 54: 1948S-1951S (1994).

5. Mirvish SS. Inhibition by vitamins $C$ and $E$ of $i n$ vivo nitrosation and vitamin $C$ occurrence in the stomach. Eur J Cancer Prev 5: 131-136 (1996).

6. Leaf CD, Vecchio AJ, Roe DA, Hotchkiss JH. Influence of ascorbic acid dose on Nnitrosoproline formation in humans. Carcinogenesis 8: 791-795 (1987).

7. Helser MA, Hotchkiss JH, Roe DA. Temporal influence of ascorbic acid dose on the endogenous formation of N-nitrosoproline and N-nitrosothiazolidine-4-carboxylic acid in humans. J Nutr Biochem 2: 268-273 (1991).

8. Yang CS, Wang Z-Y. Tea and cancer. J Natl Cancer Inst 85: 1038-1049 (1993).

9. Katiyar SK, Mukhtar H. Tea in chemoprevention of cancer: epidemiologic and experimental studies. Int J Oncol 8: 221-238 (1996).

10. Blot WJ, Chow W-H, McLaughlin JK. Tea and cancer: a review of the epidemiological evidence. Eur J Cancer Prev 5: 425-438 (1996).

11. Katiyar SK, Mukhtar H. Tea antioxidants in cancer chemoprevention. J Cell Biochem Suppl 27: 59-67 (1997).

12. Wu Y-N, Wang H-Z, Li J-S, Han C. The inhibitory effect of Chinese tea and its polyphenols on in vitro and in vivo N-nitrosation. Biomed Environ Sci 6: 237-258 (1993).

13. Graham HN. Green tea composition, consumption, and polyphenol chemistry. Prec Med 21: 334-350 (1992).

14. Serafini M, Ghiselli A, Ferro-Luzzi A. In vivo antioxidant effect of green and black tea in man. Eur J Clin Nutr 50: 28-32 (1996).

15. Stich HF, Chan PKL, Rosin MP. Inhibitory effect of phenolics, teas and saliva on the formation of mutagenic nitrosation products of salted fish. Int J Cancer 30: 719-724 (1982).

16. Stich HF. Teas and tea components as inhibitors of carcinogen formation in model systems and man. Prev Med 21: 377-384 (1992).

17. Xu GP, Song PJ, Reed RI. Effects of fruit juices, processed vegetable juice, orange peel and green tea on endogenous formation of $\mathrm{N}$-nitrosoproline in subjects from a high-risk area for gastric cancer in Moping County, China. Eur I Cancer Prev 2: $327-$ 335 (1993).

18. Wagner DA, Shuker DEG, Bilmazes C, Obiedzinski M, Young VR, Tannenbaum SR. Modulation of endogenous synthesis of N-nitrosamino acids in humans. in: O'Neill IK, von Borstel RC, Miller CT, Long J, Bartsch H (Eds). N-nitroso compounts: 
occurrence, biological effects and relevance to human cancer. IARC Scientific Publications No. 57, International Agency for Research on Cancer, Lyon, pp. 223-229 (1984).

19. Vermeer ITM, Pachen DMFA, Dallinga JW, Kleinjans JCS, Van Maanen JMS. Volatile $\mathrm{N}$-nitrosamine formation after intake of nitrate at the ADI level in combination with an amine-rich diet. Environ Health Perspect 106: 459-463 (1998).

20. Von Beutler HO, Wurst B, Fischer S. Eine neue methode zur enzymatischen bestimmung von nitrat in lebensmitteln. Deut Lebensm-Rundsch 82: 283-289 (1986).

21. Cicchetti DV. Multiple comparison methods: establishing guidelines for their valid application in neuropsychological research. I Clin Exp Neuropsychol 16: 155-161 (1994).

22. Mirvish SS. Effects of vitamins $C$ and $E$ on $N$-nitroso compound formation, carcinogenesis, and cancer. Cancer 58: 1842-1850 (1986).

23. Van Maanen JMS, Moonen EJC, Maas LM, Kleinjans JCS, Van Schooten FJ. Formation of aromatic DNA adducts in white blood cells in relation to urinary excretion of 1-hydroxypyrene during consumption of grilled meat. Carcinogenesis 15: 2263-2268 (1994).

24. Wagner DA, Shuker DEG, Bilmazes C, Obiedzinski M, Baker I, Young VR, Tannenbaum SR. Effects of vitamins $C$ and $E$ on endogenous synthesis of $N$ nitrosamino acids in humans: precursor-product studies with [ $\left[{ }^{15} \mathrm{~N}\right]$ nitrate. Cancer Res 45: 6519-6522 (1985).

25. Mirvish SS, Grandjean AC, Reimers KJ, Connelly BJ, Chen SC, Morris CR, Wang X, Haorah J, Lyden ER. Effect of ascorbic acid dose taken with a meal on nitrosoproline excretion in subjects ingesting nitrate and proline. Nutr Cancer 31: 106-110 (1998).

26. Garland WA, Kuenzig W, Rubio F, Kornychuk H, Norkus EP, Conney AH. Urinary excretion of nitrosodimethylamine and nitrosoproline in humans: interindividual and intraindividual differences and the effect of administered ascorbic acid and alpha-tocopherol. Cancer Res 46: 5392-5400 (1986).

27. Rathbone BJ, Johnson AW, Wyatt JI, Kelleher J, Heatley RV, Losowsky MS. Ascorbic acid: a factor concentrated in human gastric juice. Clin Sci 76: 237-241 (1989).

28. Jacob RA, Skala JH, Omaye ST. Biochemical indices of human vitamin C status. Am J Clin Nutr 46: 818-826 (1987).

29. O'Conner HJ, Habibzedah N, Schorah CJ, Axon ATR, Riley SE, Garner RC. Effect of increased intake of vitamin $C$ on the mutagenic activity of gastric juice and intragastric concentrations of ascorbic acid. Carcinogenesis 6: 1675-1676 (1985).

30. Yang CS, Chen L, Lee M-J, Balentine D, Chen Kuo M, Schantz SP. Blood and urine levels of tea catechins after ingestion of different amounts of green tea by human volunteers. Cancer Epidemiol Biomarkers Prev 7: 351-354 (1998).

31. Nakamura M, Kawabata T. Effect of Japanese green tea on nitrosamine formation in vitro. J Food Sci 46: 306-307 (1981).

32. Pignatelli B, Bereziat J-C, Descotes $G$, Bartsch $\mathrm{H}$. Catalysis of nitrosation in vitro and in vivo in rats by catechin and resorcinol and inhibition by chlorogenic acid. Carcinogenesis 3: 1045-1049 (1982).

33. Davies R, Dennis MJ, Massey RC, McWeeny DJ. Some effects of phenol- and thiolnitrosation reactions on N-nitrosamine formation. in: Walker EA, Griciute L, Castegnaro M, Lyle RE (Eds). Envirommental aspects of $N$-nitroso compounds. IARC Scientific Publications No. 19, International Agency for Research on Cancer, Lyon, pp. 183-197 (1978). 
34. Spiegelhalder B, Eisenbrand G, Preussmann R. Influence of dietary nitrate on nitrite content of the human saliva: possible relevance to in vivo formation of $\mathrm{N}$-nitroso compounds. Food Cosmet Toxicol 14: 545-548 (1976). 


\section{Chapter 5}

\section{Intragastric volatile nitrosamines, nitrite, and $\mathrm{pH}$ during long-term treatment with omeprazole}

I.T.M. Vermeer

L.G.J.B. Engels*

D.M.F.A. Pachen

J.W. Dallinga

E. van Agen

J.C.S. Kleinjans

J.M.S. van Maanen

Submitted for publication

Department of Health Risk Analysis and Toxicology, Maastricht University, P.O. Box 616, 6200 MD Maastricht, The Netherlands

*Department of Gastroenterology, Maasland Hospital Sittard, The Netherlands 


\section{Abstract}

Background and aims: Long-term gastric acid suppressive therapy may give rise to increased intragastric formation of potentially carcinogenic $\mathrm{N}$-nitroso compounds. This study evaluated the effect of chronic treatment with omeprazole on intragastric levels of volatile N-nitrosamines and related intragastric parameters. Methods: 45 patients with reflux oesophagitis on long-term omeprazole medication (mean 35 months), and 13 healthy subjects without medication, participated in this study. Gastric juice and gastric biopsies were sampled after an overnight fast, and an early-morning urine sample was collected. Volatile Nnitrosamines were determined in gastric juice and urine. The gastric juice was also analyzed for nitrate and nitrite levels and $\mathrm{pH}$. DNA isolated from gastric biopsies was analyzed for alkyl-DNA adducts and K-ras mutations as markers for carcinogenic events.

Results: The intragastric $\mathrm{pH}$ in the patients was significantly higher compared with the control subjects $(p=0.0001)$. Gastric nitrite levels in the patient group were higher, but this was not significant. There was no difference in the total level of intragastric volatile $\mathrm{N}$-nitrosamines between the patients and the control subjects, however, urinary $\mathrm{N}$-nitrosodimethylamine excretion was higher in the patient group ( $\mathrm{p}=0.001)$. No N7-methylguanosine and N7-ethylguanosine adduct levels were found in gastric epithelial cells above the detection limit of 1 adduct per $10^{6}$ nucleotides. No K-ras codon 12 mutations were detected. Furthermore, duration of omeprazole therapy was not related to the level of intragastric volatile $\mathrm{N}$-nitrosamines or excretion of volatile $\mathrm{N}$-nitrosamines in urine.

Conclusions: These results demonstrate that increased intragastric $\mathrm{pH}$ due to longterm treatment with omeprazole does not result in increased intragastric levels of nitrite and volatile N-nitrosamines. The significantly higher urinary $\mathrm{N}$ nitrosamine excretion implies the risk of increased endogenous formation of $\mathrm{N}$ nitrosamines during long-term omeprazole treatment. 


\section{Introduction}

Although stomach cancer rates have declined worldwide over the last decades, its frequency still rates second after lung cancer (1). Dietary constituents, hypochlorhydria, bacterial overgrowth, and Helicobacter pylori infection have been reported as important risk factors for gastric cancer (2-6). Dietary factors include high salt intake, low intake of fresh fruits and vegetables (containing vitamins and anti-oxidants), and nitrate intake, leading to intragastric formation of $\mathrm{N}$-nitroso compounds (NOC) (2).

Formation of NOC may occur spontaneously in the acidic stomach (chemical nitrosation), or at neutral $\mathrm{pH}$ catalyzed by bacteria (7-9). Prolonged hypochlorhydria is associated with bacterial overgrowth (10). Intragastric bacteria with nitrate reducing activity may give rise to increased nitrite formation and subsequently, intragastric synthesis of $\operatorname{NOC}(11,12)$. Nitrites have been positively associated with gastric cancer risk $(13,14)$. Furthermore, the intake of preformed NOC (e.g. nitrosodimethylamine) is also positively associated with increased gastric cancer risk (14). In gastric cancer patients, a high incidence of G:C->A:T transitions has been found in DNA isolated from gastric carcinoma (15). These transitions are common in the mutation spectrum induced by NOC as demonstrated in vitro and in vivo, supporting the hypothesis that NOC play a role in gastric carcinogenesis (16). G:C->A:T transitions also have been observed in codon 12 of the K-ras gene in lung tumors after exposure of laboratory animals to nitrosamines $(17,18)$.

Proton pump inhibitors, such as omeprazole, are widely prescribed. These drugs cause a profound decrease in secretion of gastric acid, resulting in an increased $\mathrm{pH}$ in the stomach $(5,19)$. Serious concerns persist with long-term acid suppression, since powerful inhibitors of gastric secretion, such as omeprazole, induce gastric carcinoids in experimental animals $(20,21)$. Calmels et al. demonstrated that omeprazole-treated rats gavaged with nitrate reducing and nitrosating bacteria, synthesized NOC in the stomach (8). Clinical studies conclusively showed a significant increase in bacterial gastric colonization in humans after treatment with $20 \mathrm{mg}$ omeprazole daily (22-28). Four studies with human volunteers and patients on the effect of short-term use of omeprazole on intragastric nitrate, nitrite and NOC have been performed, with conflicting results (22-25). However, many patients chronically take omeprazole. Long-term use of omeprazole implies a high risk of increased nitrite and NOC formation. Within this respect, the aim of the present study is to assess the possible carcinogenic risk of long-term treatment with omeprazole. Therefore, we analyzed intragastric Nnitrosamine concentrations as a function of nitrite and nitrate levels in gastric juice, and intragastric pH, in association with N7-methyl- and ethylguanosine adducts and K-ras mutations in DNA from gastric biopsies, obtained from 
patients with reflux oesophagitis on long-term medication of omeprazole, and compared these parameters with results from healthy control subjects.

\section{Methods}

\section{Subjects}

Fourty-five patients (26 men and 19 women, mean age $60 \pm 13$ years, range 23-84 years) with various degrees of reflux oesophagitis agreed to participate in this study and signed an informed consent. The study was approved by the medical ethical committee of the Hospital in Sittard. The patients were on long-term omeprazole therapy (20 $\mathrm{mg}$ daily), on average for $35 \pm 24$ months (mean $\pm \mathrm{SD}$, range 3-89 months). They collected an early-morning urine sample, and answered to a questionnaire on lifestyle habits regarding smoking, alcohol intake, use of vitamin preparations, and intake of fresh fruits. Gastroscopy was performed to collect gastric juice as well as four gastric biopsies from antrum and two from corpus. Patients were asked to take their daily omeprazole prior to the gastroscopy. Thirteen healthy subjects (10 men and 3 women, mean age $59 \pm 8$ years, range 48-72 years) without any medical therapy were included in the study. In these healthy controls no mucosal disease was permitted. Endoscopies were performed by one co-author (L.G.J.B.E.).

\section{Collection and storage of gastric juice and urine samples}

The $\mathrm{pH}$ of the gastric juice was determined using a $\mathrm{pH}$ meter with a glass electrode (Beckman, Mijdrecht, The Netherlands). Gastric juice samples were stabilized with $0.1 \mathrm{ml} 1 \mathrm{M} \mathrm{NaOH}$ per $\mathrm{ml}$ gastric juice. 1 gram of $\mathrm{NaOH}$ pellets was added to $100 \mathrm{ml}$ of the early-morning urine sample. Gastric juice and urine samples were stored at $-20^{\circ} \mathrm{C}$ until analysis.

\section{Analysis of nitrate and nitrite in gastric juice}

Gastric juice samples were centrifuged for $10 \mathrm{~min}$ at $12,000 \mathrm{~g}$. The supernatant was diluted with $\mathrm{dH}_{2} \mathrm{O}$ and the sample was extracted using a preconditioned reversed-phase cartridge (maxi-clean ${ }^{\mathrm{TM}}$ IC-RP, Alltech, Deerfield, IL, USA) in line with a preconditioned silver cartridge (maxi-clean ${ }^{\mathrm{TM}} \mathrm{IC}-\mathrm{Ag}$, Alltech) to remove organic compounds and chloride ions, respectively. The eluate was stored at $20^{\circ} \mathrm{C}$ until analysis. After thawing the eluate for analysis, the sample was finally purified through a $0.2 \mu \mathrm{m}$ filter (Alltech).

Nitrate and nitrite concentrations in gastric juice were determined by HPLC-UV using anion-exchange chromatography as previously described (29). 
Analysis of volatile nitrosamines in gastric juice and urine

Gastric juice and urine samples were analyzed for the following volatile Nnitrosamines: N-nitrosodimethylamine (NDMA), N-nitrosomethylethylamine (NMEA), N-nitrosodiethylamine (NDEA), N-nitrosopiperidine (NPIP) and $\mathrm{N}$ nitrosomorpholine (NMOR). Gastric juice was additionally screened for $\mathrm{N}$ nitrosopyrrolidine (NPYR) and N-nitroso-di-n-butylamine (NDBA). A $20 \mathrm{ml}$ urine aliquot and a $5 \mathrm{ml}$ gastric juice aliquot, respectively, were extracted with $1 \mathrm{ml}$ of dichloromethane. The dichloromethane solutions were analyzed by gas chromatography-mass spectrometry (GC-MS) as previously described (30).

\section{Detection of creatinine in urine}

Excretion of volatile N-nitrosamines in urine was expressed as $\mathrm{nmol} / \mathrm{mmol}$ creatinine and $\mathrm{mg} / \mathrm{mmol}$ creatinine, respectively. Creatinine levels in urine were determined spectrophotometrically using a diagnostic kit (Sigma, kit no. 555-A, St. Louis, MO, USA).

Analysis of N7-methylguanosine and N7-ethylguanosine adducts by immunoslot blot assay

DNA was isolated from three gastric biopsies ( 2 from antrum and 1 from corpus) as previously described (31). In short: the samples were homogenized in SDS/EDTA and subsequently incubated with proteinase $\mathrm{K}$. The homogenate was extracted with phenol, phenol/chloroform/isoamyl alcohol (25:24:1) and chloroform/isoamyl-alcohol (24:1). After DNA precipitation, RNA was removed by incubation with RNase $\mathrm{A}$ and RNase T1. DNA was precipitated again after another extraction with chloroform/isoamylalcohol.

The mean DNA recovery from the three gastric biopsies was about $40 \mu \mathrm{g}$. DNA from the gastric biopsies was dissolved in $10 \mathrm{mM} \mathrm{KH}_{2} \mathrm{PO}_{4}-\mathrm{KOH}, \mathrm{pH} 7.0$, to a final concentration of $50 \mu \mathrm{g} / \mathrm{ml}$. The DNA was sonicated for $5 \mathrm{~s}$, followed by ringopening of N7-alkylguanine adducts: per $200 \mu \mathrm{l}$ of DNA solution $4.7 \mu \mathrm{l}$ of $3 \mathrm{M}$ $\mathrm{NaOH}$ were added followed by incubation for $30 \mathrm{~min}$ at $37^{\circ} \mathrm{C}$. The solution was neutralized by addition of $6 \mu \mathrm{l}$ of $1 \mathrm{M} \mathrm{KH}_{2} \mathrm{PO}_{4}$ and $15-16 \mu \mathrm{l}$ of $1 \mathrm{M} \mathrm{HCL}$ until $\mathrm{pH}$ 7.4. After addition of $275 \mu \mathrm{l}$ PBS the sample was incubated for $5 \mathrm{~min}$ at $100^{\circ} \mathrm{C}$ and for $10 \mathrm{~min}$ at $0^{\circ} \mathrm{C}$. Finally $500 \mu \mathrm{l}$ of $2 \mathrm{M} \mathrm{NH}_{4} \mathrm{Ac}$ were added and the DNA concentration was determined spectrophotometrically. The immunoslot blot assay was performed as described by Van Delft et al. (32) with some modifications. The nitrocellulose filter with the DNA samples was heated at $80^{\circ} \mathrm{C}$ for $1 \mathrm{~h}$. The filter was incubated overnight in $0.5 \times \mathrm{PBS}, 0.1 \%$ Tween-20, 0.5\% milk powder and 20,000-fold diluted first antibody N7E-026 (a gift from Van Delft). This monoclonal antibody specifically recognizes ring-opened N7-methylguanosine and N7-ethylguanosine adducts (33). After washing, the filter was incubated for 1 h with a 10,000-fold dilution of the second antibody RAM-PO (Dako, Denmark) in 
PBS, $0.1 \%$ Tween-20 and $0.5 \%$ milk powder. A chemiluminescence kit (Supersignal Nucleic Acid from Pierce, USA) was used for detection of the DNA adducts. The detection limit of this method is 1 adduct per $10^{\circ}$ nucleotides.

\section{Detection of K-ras codon 12 mutation}

Detection of K-ras codon 12 mutation was performed as previously described with some modifications (34). $1 \mu \mathrm{g}$ of DNA was amplified in a reaction mixture of $95 \mu \mathrm{l}$ containing PCR reaction buffer: $50 \mathrm{mM} \mathrm{KCl}, 10 \mathrm{mM}$ Tris $\mathrm{pH} 8.3,1.5 \mathrm{mM}$ $\mathrm{MgCl}, 0.01 \%$ (w/v) gelatin, $0.2 \mathrm{mM}$ dNTPs, $200 \mathrm{ng}$ of primers, and 2.5 units of Taq DNA polymerase. The mixture was covered with mineral oil and DNA was amplified in 40 cycles: 1 min of denaturation at $94^{\circ} \mathrm{C}, 2$ min of reannealing at $50^{\circ} \mathrm{C}$ and 3 min of elongation at $72^{\circ} \mathrm{C}$. PCR amplified samples were digested with the restriction enzyme BstNI at $60^{\circ} \mathrm{C}$ for 3 hours.

\section{Statistical analysis}

Results are presented as mean \pm SD. Comparison of various parameters between the patient group and the control subjects was performed using the nonparametric Mann-Whitney test. Spearman rank correlations were used to determine possible relationships between the different parameters measured in the patient group. A p-value $<0.05$ was considered statistically significant.

\section{Results}

Gastric contents of nitrate and nitrite in patients were compared with the levels in healthy volunteers. The results of the nitrate and nitrite analyses in gastric juice are presented in Table 1. Nitrate levels in gastric juice were not significantly different between the patient group and the control subjects. Intragastric nitrite levels in the patient group were higher than in the control subjects; this difference was not statistically significant (Mann-Whitney, $p=0.07$ ).

Mean $\mathrm{pH}$ of the gastric juice samples from patients was $5.9 \pm 2.4$ (range 1.68.6). $35 \%$ of the samples showed a pH $<4 ; 5 \%$ a pH between 4 and 6 , and $60 \%$ of the samples a $\mathrm{pH}>6$. Mean intragastric $\mathrm{pH}$ of the control subjects was $2.5 \pm 1.6$; this was significantly lower than in the patient group (Mann-Whitney, $p=0.0001$ ).

The levels of the individual volatile $\mathrm{N}$-nitrosamines detected in gastric juice and urine are presented in Table 1. The predominant volatile N-nitrosamine present in gastric juice and urine was NDMA, detected in $45 \%$ and $54 \%$ of the gastric juice samples from patients and control subjects, respectively, and in $88 \%$ and $92 \%$ of the urine samples from patients and control subjects, respectively. NMEA, NMOR and NDBA were not detected in the samples. Intragastric levels of $\mathrm{N}$-nitrosamines were not significantly different between the patient group and the 
control subjects, except for NPIP. Intragastric NPIP was detected in $2 \%$ of the patients compared with $46 \%$ of the control subjects, and the intragastric levels of NPIP were significantly lower in the patient group (Mann-Whitney, $p=0.015$ ). NDMA excretion in urine was significantly higher in the patient group compared with the control group (Mann-Whitney, $\mathrm{p}=0.001$ ). In the patient group, intragastric levels of nitrosamines showed two peaks: one at low $\mathrm{pH}(\mathrm{pH} 1-5)$ and one at high pH (pH 5-9, Figure 1). There was no significant difference between the mean nitrosamine concentrations at low and high $\mathrm{pH}: 2.44 \pm 2.90 \mathrm{nmol} / 1$ and 3.10 $\pm 6.39 \mathrm{nmol} / \mathrm{l}$, respectively.

Table 1. Mean intragastric concentration \pm SD of nitrate and nitrite $(\mathrm{mg} / \mathrm{l})$, of volatile $\mathrm{N}$-nitrosamines $(\mathrm{nmol} / \mathrm{l})$, intragastric $\mathrm{pH}$, and urinary excretion of $\mathrm{N}$-nitrosamines ( $\mathrm{nmol} / \mathrm{mmol}$ creatinine) in a group of patients on proton pump inhibitor therapy and a control group and the percentage positive samples

\begin{tabular}{|c|c|c|c|c|}
\hline & \multicolumn{2}{|c|}{ PATIENT GROUP } & \multicolumn{2}{|c|}{ CONTROL SUBJECTS } \\
\hline & Gastric juice & Urine & Gastric juice & Urine \\
\hline $\begin{array}{l}\text { Nitrate } \\
\text { range }\end{array}$ & $\begin{array}{l}14.9 \pm 9.7 \\
1.1-36.7\end{array}$ & & $\begin{array}{l}18.2 \pm 19.0 \\
3.0-76\end{array}$ & \\
\hline $\begin{array}{l}\text { Nitrite } \\
\text { range }\end{array}$ & $\begin{array}{l}1.16 \pm 0.87 \\
0.10-4.10\end{array}$ & & $\begin{array}{l}0.69 \pm 0.31 \\
0.13-1.10\end{array}$ & \\
\hline $\mathrm{pH}$ & $5.9 \pm 2.4^{\#}$ & & $2.5 \pm 1.6$ & \\
\hline $\begin{array}{l}\text { NDMA } \\
\% \text { positive }\end{array}$ & $\begin{array}{l}2.48 \pm 5.28 \\
45 \%\end{array}$ & $\begin{array}{l}2.45 \pm 2.70 * \\
88 \%\end{array}$ & $\begin{array}{l}3.41 \pm 4.29 \\
54 \%\end{array}$ & $\begin{array}{l}0.49 \pm 0.37 \\
92 \%\end{array}$ \\
\hline $\begin{array}{l}\text { NPIP } \\
\% \text { positive }\end{array}$ & $\begin{array}{l}0.01 \pm 0.03^{\#} \\
2 \%\end{array}$ & $\begin{array}{l}0.25 \pm 0.23 \\
83 \%\end{array}$ & $\begin{array}{l}0.25 \pm 0.32 \\
46 \%\end{array}$ & $\begin{array}{l}0.22 \pm 0.11 \\
92 \%\end{array}$ \\
\hline $\begin{array}{l}\text { NPYR } \\
\% \text { positive }\end{array}$ & $\begin{array}{l}0.10 \pm 0.20 \\
24 \%\end{array}$ & ND & $\begin{array}{l}0.16 \pm 0.22 \\
15 \%\end{array}$ & ND \\
\hline $\begin{array}{l}\text { NDEA } \\
\% \text { positive }\end{array}$ & $\begin{array}{l}0.27 \pm 0.64 \\
17 \%\end{array}$ & ND & $\begin{array}{l}0.17 \pm 0.39 \\
8 \%\end{array}$ & ND \\
\hline Total volatile & & & & \\
\hline$N$-nitrosamines & $2.85 \pm 5.30$ & $2.70 \pm 2.80^{* *}$ & $3.79 \pm 4.47$ & $0.72 \pm 0.43$ \\
\hline $\begin{array}{l}\text { \#Significantly high } \\
\text { * Significantly high } \\
\text { *\# Significantly low } \\
\text { ** Significantly hig } \\
\text { ND: Non Detectab }\end{array}$ & $\begin{array}{l}\text { compared witl } \\
\text { compared witl } \\
\text { compared witl } \\
\text { r compared wi }\end{array}$ & $\begin{array}{l}\text { e control subjec } \\
\text { le control subjec } \\
\text { e control subjec } \\
\text { he control subje }\end{array}$ & $\begin{array}{l}\text { (Mann-Whitne } \\
\text { (Mann-Whitne } \\
\text { (Mann-Whitne } \\
\text { s (Mann-Whitn }\end{array}$ & $\begin{array}{l}=0.0001) \\
=0.001) \\
=0.015) \\
p=0.004)\end{array}$ \\
\hline
\end{tabular}


DNA was isolated from the gastric biopsies and 52 samples (39 from the patient group and 13 from the control subjects) were screened for N7methylguanosine and N7-ethylguanosine adducts. The adduct levels in the DNA samples appeared below detection limit. The DNA samples were also analyzed for codon 12 mutations of the K-ras gene. No K-ras mutations could be identified in the samples.

Spearman rank correlations showed that the level of intragastric volatile Nnitrosamines was not related to the duration of proton pump inhibitor therapy (Figure 2), intragastric nitrite- or nitrate levels, gastric $\mathrm{pH}$, and age. Furthermore, urinary N-nitrosamine excretion was not related to duration of proton pump inhibitor therapy. There was a correlation between intragastric $\mathrm{pH}$ and nitrite levels in gastric juice ( $\mathrm{r}=0.52 ; \mathrm{p}=0.001)$ and an inverse relationship between $\mathrm{pH}$ and intragastric nitrate levels $(r=-0.47 ; \mathrm{p}=0.027)$. Intragastric nitrite levels correlated with NDMA excretion in urine ( $\mathrm{r}=0.48 ; \mathrm{p}=0.0028)$.

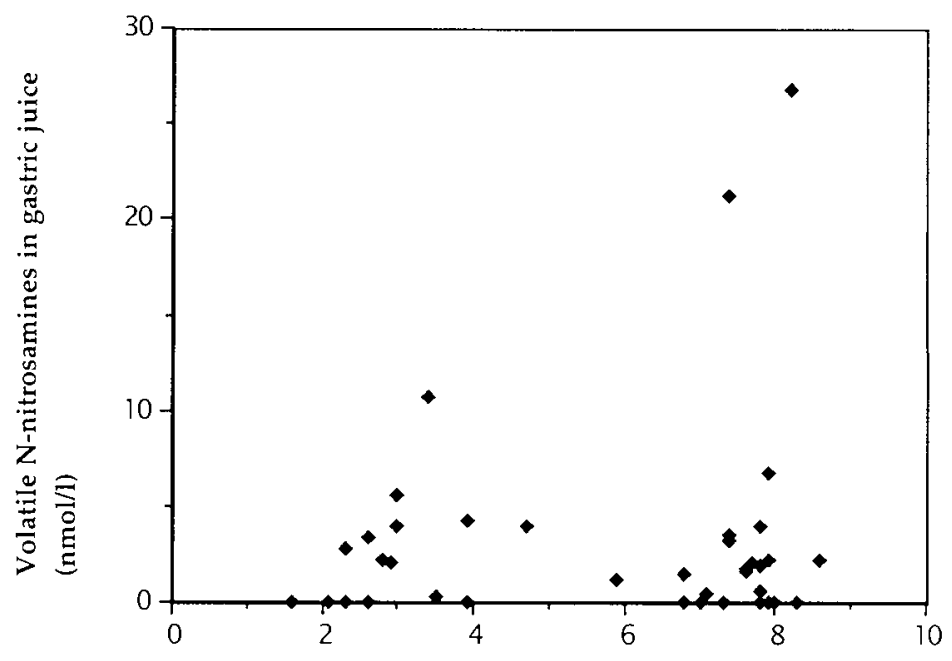

Figure 1. Relationship between volatile N-nitrosamines in gastric juice and intragastric $\mathrm{pH}$. 


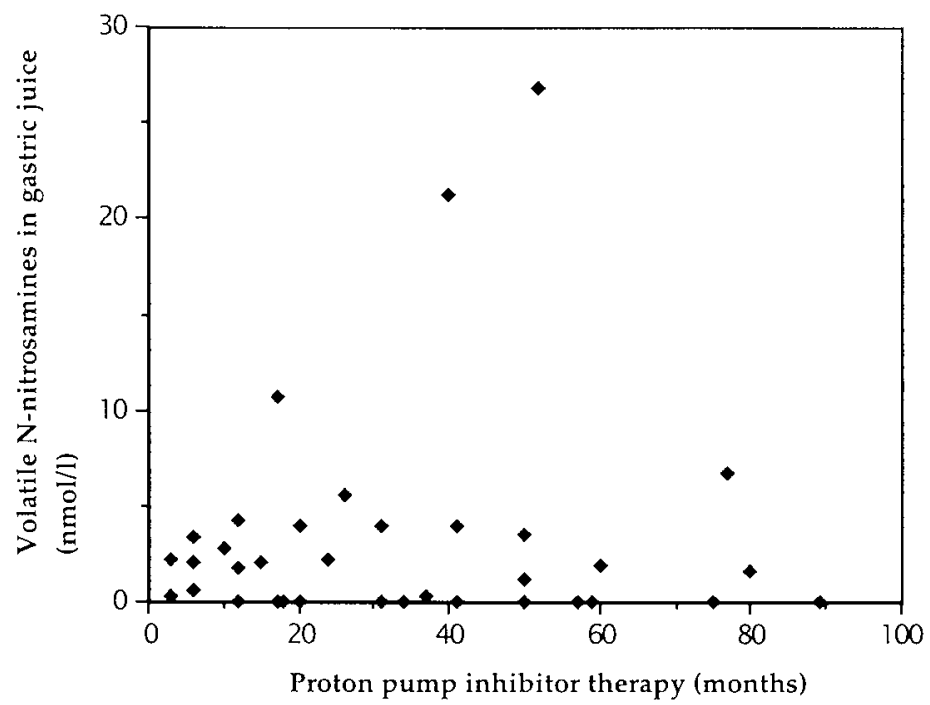

Figure 2. Relationship between volatile N-nitrosamines in gastric juice and duration of proton pump inhibitor therapy.

\section{Discussion}

In the last two decades several research groups developed methods to measure total NOC as a group in biological fluids applying a thermal energy analyzer (TEA) (36-39). In the present study, we have measured individual volatile Nnitrosamines in gastric juice and urine with high-resolution GC-MS, a sensitive and specific method routinely applied in our laboratory $(30,40-43)$. This method has the advantage of measuring individual NOC, based on the GC retention time and the elemental composition of the detected ions. Within the scope of our hypothesis, we specifically wanted to study nitrosamines which are known to be carcinogenic. In collaboration with TNO Nutrition and Food Research Institute in Zeist, The Netherlands, and The National Institute of Public Health and the Environment in Bilthoven, The Netherlands, we compared our GC-MS assay with the GC-TEA assay (unpublished results). There was a strong correlation between the two assays $\left(R^{2}=0.86 ; p=0.0001\right)$, demonstrating the exchangeability of both methods.

Intragastric levels of nitrate and nitrite, detected in the present study, are comparable with results from another study in patients treated with omeprazole 
(22) and from studies in patients with precancerous lesions of the stomach $(44,45)$. There was a significant relationship between nitrite levels in gastric juice and intragastric pH. Probably, the higher nitrite levels at higher pH can partly be explained by bacterial nitrate reductase activity and partly because nitrite is more stable in a neutral environment (9). This can also explain the higher gastric nitrite levels in the patient group compared with the control subjects with a lower intragastric $\mathrm{pH}$.

Individual volatile $\mathrm{N}$-nitrosamines were detected in gastric juice and urine samples. The intragastric total volatile nitrosamine levels are in the same range as the levels measured by $X_{u}$ et al. (46) and Dallinga et al. (43). There was no significant difference in the level of total volatile N-nitrosamines present in gastric juice between the patient group and the control subjects. However, the intragastric levels of NPIP were lower in the patient group compared with the control subjects. This may be related to differences in coffee consumption, as was recently suggested (47). Unfortunately, coffee consumption was not assessed in this study. The significantly higher nitrosamine excretion in urine in the patient group may indicate a higher total $\mathrm{N}$-nitrosamine formation over a prolonged period of time. This does not necessarily reflect nitrosamine formation in the stomach. It should be noted that intragastric levels of nitrite and NOC are the result of several kinetic processes. Firstly, the production of gastric juice is a contributing factor, and this is decreased by omeprazole treatment. The volume of gastric juice from the study population appeared to be highly variable between individuals. Secondly, the rate of gastric emptying is important, and finally, the rate of formation of nitrite and NOC plays a role. It is possible that besides endogenous NOC formation in the stomach, NOC formation also occurs in the intestine. It has been reported that duodenal bacterial overgrowth occurs frequently in patients treated with omeprazole (48). Consequently, duodenal formation of NOC will give rise to increased urinary NOC excretion. Since gastric juice reflects the levels of NOC over a relatively short period of time, depending on the kinetic parameters, urine might be an additional parameter that more reliably reflects the levels of NOC over a prolonged period of time, and also including possible endogenous formation in the intestine.

Intragastric formation of NOC may occur both in an acidic environment and in a neutral environment catalyzed by bacteria (in the achlorhydric, colonized stomach) $(7,8,49)$. The present study confirms that both at low and at neutral $\mathrm{pH}$ considerable intragastric NOC formation can take place, in line with other studies $(9,43,46)$. However, since only $5 \%$ of the patients had a gastric $\mathrm{pH}$ between 4 and 6 , a real comparison between NOC concentrations in the low and neutral $\mathrm{pH}$ range with the NOC concentrations in the intermediate $\mathrm{pH}$ range is not possible. The nitrosamine level at neutral $\mathrm{pH}$ does indicate that endogenous formation of nitrosamines by intragastric bacteria did occur. In 35\% of the gastric juice samples 
the $\mathrm{pH}<4$. This might be explained by the phenomenon 'nocturnal acid breakthrough' (50). DNA from gastric biopsy samples was analyzed for K-ras codon 12 mutation and N7-alkylguanosine adducts. Concerning the alkyl adducts, we expected that higher intragastric $\mathrm{N}$-nitrosamine levels would result in higher N7-methyl and ethylguanosine DNA-adduct levels in gastric mucosa cells. However, no DNA-adduct levels in the gastric biopsy samples were observed above the detection limit of 1 adduct per $10^{6}$ nucleotides. Unfortunately, this detection limit is relatively high and adduct levels below 1 adduct per $10^{6}$ nucleotides can be of considerable importance. For comparison, occupational nitrosamine exposure in the rubber industry resulted in mean N7methylguanosine adducts from 1.2-5.0 per $10^{7} \mathrm{dG}$ nucleosides in peripheral blood lymphocytes (51). Furthermore, no K-ras mutations were found in DNA from gastric biopsies. Studies with laboratory animals showed the capacity of nitrosamines to induce lung tumors by activation of the $\mathrm{K}$-ras proto-oncogene, and the activating mutation was localized at codon $12(17,18)$. In rats, the protective effect of omeprazole on gastric mucosa injury, induced by ethanolHCL, was investigated (52). Omeprazole appeared to protect the gastric mucosa from necrotic damage. Omeprazole may also protect the gastric mucosa cells from the DNA damaging NOC, explaining the absence of $\mathrm{K}$-ras codon 12 mutations and alkylguanosine adducts above detection limit in gastric biopsies in the present study.

Sharma et al. (22) studied 10 healthy volunteers who received $30 \mathrm{mg}$ omeprazole for 14 days. They found a significant increase in bacterial count, and intragastric nitrite and total $\mathrm{N}$-nitrosamine levels; within three days after the last treatment, these changes had been reversed. A comparable study administrating $20 \mathrm{mg}$ of omeprazole daily to 14 healthy volunteers was performed by Verdu et al. (23). They found an association between omeprazole treatment and gastric bacterial proliferation, but no increase in total NOC, nitrate and nitrite levels. Thorens et al. (24) studied 47 patients with reflux oesophagitis, duodenal ulcer, gastric ulcer, gastric erosions or duodenal erosions, receiving $20 \mathrm{mg}$ of omeprazole for four weeks. The incidence of bacterial overgrowth increased, but there were no changes in intragastric total NOC, nitrite and nitrate levels. Houben et al. (25) performed a study with 11 healthy volunteers receiving $20 \mathrm{mg}$ or $40 \mathrm{mg}$ omeprazole for two weeks. This resulted in an increase of bacterial flora in the gastric juice, but nitrate, nitrite and NOC levels did not change. The patients in our study received long-term treatment with omeprazole ( $20 \mathrm{mg}$ daily for 3 years) and this resulted in an increase in intragastric $\mathrm{pH}$ and nitrite levels (not significant), but did not lead to higher intragastric volatile N-nitrosamine levels, detectable amounts of alkyl-DNA adducts or K-ras mutations. Also, no correlation between urinary excretion of nitrosamines or the level of intragastric nitrosamines and duration of proton pump inhibitor therapy was observed. Thus, our results 
are in line with those observed by Verdu et al., Thorens et al, and Houben et al., after short-term use of omeprazole (23-25). Based on the results of our study, patients on long-term omeprazole treatment are not at high risk of increased intragastric levels of N-nitrosamines. However, omeprazole treatment does imply the risk of increased urinary $N$-nitrosamine excretion, presumably reflecting increased endogenous intra- and/or extragastric synthesis of $\mathrm{N}$-nitrosamines during long-term omeprazole treatment.

\section{References}

1. Coleman MP, Esteve J, Damiecki P, Arslan A, Renard H. Trends in cancer incidence and mortality. IARC Scientific Publication No 121. Lyon: Intemational Agency for Research on Cancer, pp. 193-224 (1993).

2. Correa P. Human gastric carcinogenesis: a multistep and multifactorial process - first American Cancer Society award lecture on cancer epidemiology and prevention. Cancer Res 52: 6735-6740 (1992).

3. Reed PI. Helicobacter pylori and gastric cancer. Eur J Cancer Prev 5: 49-55 (1996).

4. Hill MJ. Mechanisms of gastric carcinogenesis. Eur J Cancer Prev 3: 25-29 (1994).

5. Kuipers EJ. Review article: exploring the link between Helicobacter pylori and gastric cancer. Aliment Pharmacol Ther 13: 3-11 (1999).

6. Wu MS, Shun CT, Wang HP, Sheu JC, Lee WJ, Wang TH, Lin JT. Genetic alterations in gastric cancer: relation to histological subtypes, tumor stage, and Helicobacter pylori infection. Gastroenterology 112: 1457-1465 (1997).

7. Leach SA, Thompson M, Hill M. Bacterially catalysed N-nitrosation reactions and their relative importance in the human stomach. Carcinogenesis 8: 1907-1912 (1987).

8. Calmels S, Béréziat JC, Ohshima H, Bartsch H. Bacterial formation of N-nitroso compounds from administered precursors in the rat stomach after omeprazoleinduced achlorhydria. Carcinogenesis 12: 435-439 (1991).

9. Xu GP, Reed PI. N-nitroso compounds in fresh gastric juice and their relation to intragastric $\mathrm{pH}$ and nitrite employing an improved analytical method. Carcinogenesis 14: 2547-2551 (1993).

10. Stockbrugger RW. Bacterial overgrowth as a consequence of reduced gastric acidity. Scand J Gastroenterol Suppl 111: 7-16 (1985).

11. Massey RC, Key PE. An investigation of the endogenous formation of apparent total $\mathrm{N}$-nitroso compounds in conventional microflora and germ-free rats. Fd Chem Toxic 26: 595-600 (1988).

12. Suzuki K, Mitsuoka T. N-nitrosamine formation by intestinal bacteria. In: O'Neill IK, Von Borstel RC, Miller CT, et al. ed. N-nitroso compounds: Occurrence, biological effects and relevance to human cancer. IARC Scientific Publication No 57. Lyon: International Agency for Research on Cancer, pp. 275-281 (1984).

13. Risch HA, Jain M, Choi NW, Fodor JG, Pfeiffer CJ, Howe GR, Harrison LW, Craib $\mathrm{KJP}$, Miller AB. Dietary factors and the incidence of cancer of the stomach. Am I Epidemiol 122: 947-959 (1985). 
14. Gonzalez CA, Riboli E, Badosa J, Batiste E, Cardona T, Pita S, Sanz JM, Torrent M, Agudo A. Nutritional factors and gastric cancer in Spain. Am J Epidemiol 139: 466-473 (1994).

15. Ranzani GN. Genetic alterations in gastric cancer. Ann 1st Super Sanita 32: 101-110 (1996).

16. Kyrtopoulos SA, Anderson LM, Chhabra SK, Souliotis VL, Pletsa V, Valavanis C, Georgiadis P. DNA adducts and the mechanism of carcinogenesis and cytotoxicity of methylating agents of environmental and clinical significance. Cancer Detect Prev 21: 391-405 (1997).

17. Belinsky SA, Devereux TR, Anderson MW. Role of DNA methylation in the activation of proto-oncogenes and the induction of pulmonary neoplasia by nitrosamines. Mutat Res 233: 105-116 (1990).

18. Devereux TR, Anderson MW, Belinsky SA. Role of ras protooncogene activation in the formation of spontaneous and nitrosamine-induced lung tumors in the resistant C3H mouse. Carcinogenesis 12: 299-303 (1991).

19. Sachs G, Shin JM. The pharmacology of the gastric acid pump: The $\mathrm{H}^{+}, \mathrm{K}^{+}$ATPase. Annu Rev Pharmacol Toxicol 35: 277-305 (1995).

20. Wormsley KG. Is chronic long-term inhibition of gastric secretion really dangerous? Scand ) Gastroenterol Suppl 146: 166-174 (1988).

21. Selway SA. Potential hazards of long-term acid suppression. Scand J Gastroenterol Suppl 178: 85-92 (1990).

22. Sharma BK, Santana IA, Wood EC, et al. Intragastric bacterial activity and nitrosation before, during, and after treatment with omeprazole. BMJ 289: 717-719 (1984).

23. Verdu E, Viani F, Armstrong D, Fraser R, Siegrist HH, Pignatelli B, Idstrom JP, Cederberg C, Blum AL, Fried M. Effect of omeprazole on intragastric bacterial counts, nitrates, nitrites, and N-nitroso compounds. Gut 35: 455-460 (1994).

24. Thorens J, Froehlich F, Schwizer W, Saraga E, Bille J, Gyr K, Duroux P, Nicolet M, Pignatelli B, Blum AL, Gonvers JJ, Fried M. Bacterial overgrowth during treatment with omeprazole compared with cimetidine: a prospective randomised double blind study. Gut 39: 54-59 (1996).

25. Houben GMP, Hooi J, Brummer R-JM, Stobberingh EE, Stockbrugger RW. Intragastric bacterial growth, nitrates, nitrites and $\mathrm{N}$-nitroso compounds after 300 mg ranitidine b.d., $20 \mathrm{mg}$ omeprazole, $40 \mathrm{mg}$ omeprazole and placebo. Eur I Cancer Prev 5 (suppl 1): 59-61 (1996).

26. Patel TA, Abraham P, Ashar VJ, Bhatia SJ, Anklesaria PS. Gastric bacterial overgrowth accompanies profound acid suppression. Indian J Gastrounterol 14: 134136 (1995).

27. Brummer R-JM, Stockbrügger RW. Effect of nizatidine $300 \mathrm{mg}$ at night and omeprazole $20 \mathrm{mg}$ in the morning on 24-hour intragastric $\mathrm{pH}$ and bacterial overgrow th in patients with acute duodenal ulcer. Dig Dis Sci 41: 2048-2054 (1996).

28. Karmeli $Y$, Stalnikowitz R, Eliakim R, Rahav G. Conventional dose of omeprazole alters gastric flora. Dig Dis Sci 40: 2070-2073 (1995).

29. Maanen JM van, Geel AA van, Kleinjans, JC. Modulation of nitrate-nitrite conversion in the oral cavity. Cancer Detect Prev 20:590-596 (1996). 
30. Vermeer ITM, Pachen DMFA, Dallinga JW, Kleinjans JCS, Van Maanen JMS. Volatile $\mathrm{N}$-nitrosamine formation after intake of nitrate at the ADI level in combination with an amine-rich diet. Environ Health Perspect 106: 459-463 (1998).

31. Gupta RC. Nonrandom binding of the carcinogen N-hydroxy-2-acetylaminofluorene to repetitive sequences of rat liver DNA in vivo. Proc Natl Acad Sci 81: 6934-6947 (1984).

32. Delft JHM van, Winden MJM van, Luiten-Schuite A, Ribeiro LR, Baan RA. Comparison of various immunochemical assays for the detection of ethylene oxideDNA adducts with monoclonal antibodies against imidazole ring-opened N7-(2hydroxyethyl)guanosine: application in biological monitoring study. Carcinogenesis 15: 1867-1873 (1994).

33. Delft JHM van, Weert EJM van, Schellekens MM, Claassen E, Baan RA. The isolation of monoclonal antibodies selected for the detection of imidazole ring-opened N7ethylguanine in purified DNA and in cells in situ. Crossreaction with methyl, 2hydroxyethyl and sulphur mustard adducts. Carcinogenesis 12: 1041-1049 (1991).

34. Jiang W, Kahn SM, Guillem JG, Lu SH, Weinstein IB. Rapid detection of ras oncogenes in human tumors: applications to colon, esophageal, and gastric cancer. Oncogene 4: 923-928 (1989).

35. Walters CL, Downes MJ, Edwards MW, Smith PL. Determination of a non-volatile N-nitrosamine on a food matrix. Analyst 103: 1127-1133 (1978).

36. Bavin PMG, Darkin DM, Viney NJ. Total nitroso compounds in gastric juice. In: Bartsch H, ONeill IK, Castegnaro M, et al. ed. N-nitroso compounds: Occurrence and Biological Effects. IARC Scientific Publication No 41. Lyon: International Agency for Research on Cancer, pp. 337-344 (1982).

37. Pignatelli B, Richard I, Bourgade MC, Bartsch H. Improved group determination of total N-nitroso compounds in human gastric juice by chemical denitrosation and thermal energy analysis. Analyst 112: 945-949 (1987).

38. Xu GP, Reed PI. A method for group determination of total N-nitroso compounds and nitrite in fresh gastric juice by chemical denitrosation and thermal energy analysis. Analyst 118: 877-883 (1993).

39. $X_{u}$ GP, Reed PI. Instability of N-nitroso compounds in gastric juice and preliminary results from analyses of fresh samples by using an improved analytical method. Eur J Cancer Prev 2: 381-386 (1993).

40. Maanen JMS van, Welle IJ, Hageman G, Dallinga JW, Mertens PL, Kleinjans JC. Nitrate contamination of drinking water: relationship with HPRT variant frequency in lymphocyte DNA and urinary excretion of N-nitrosamines. Environ Health Perspect 104: 522-528 (1996).

41. Dallinga JW, Pachen DMFA, Kleinjans JCS. Determination of volatile Nnitrosamines in gastric juice and in urine by gas chromatography-mass spectrometry. Eur J Cancer Prev 5: 63-66 (1996).

42. Maanen JMS van, Pachen DMFA, Dallinga JW, Kleinjans JC. Formation of nitrosamines during consumption of nitrate- and amine-rich foods, and the influences of the use of mouthwashes. Cancer Ditect Prev 22: 204-212 (1998).

43. Dallinga JW, Pachen DMFA, Lousberg AHP, van Geel JA, Houben GM, Stockbrugger RW, Van Maanen JM, Kleinjans JC. Volatile $\mathrm{N}$-nitrosamines in gastric juice of patients with various conditions of the gastrointestinal tract determined by 
gas chromatography-mass spectrometry and related to intragastric $\mathrm{pH}$ and nitrate and nitrite levels. Cancer Lett 124: 119-125 (1998).

44. Pignatelli B, Malaveille C, Rogatko A, Hautefeuille A, Thuillier P, Munoz N, Moulinier B, Berger F, De Montclos H, Lambert R, et al. Mutagens, N-nitroso compounds and their precursors in gastric juice from patients with and without precancerous lesions of the stomach. Eur J Cancer 29A: 2031-2039 (1993).

45. Sobala GM, Pignatelli B, Schorah CJ, Bartsch H, Sanderson M, Dixon MF, Shires S, King RF, Axon AT. Levels of nitrite, nitrate, N-nitroso compounds, ascorbic acid and total bile acids in gastric juice of patients with and without precancerous conditions of the stomach. Carcinogenesis 12: 193-198 (1991).

46. $X_{\mathrm{u}}$ GP, Song PJ, Reed PI. Hypothesis on the relationship between gastric cancer and intragastric nitrosation: $\mathrm{N}$-nitrosamines in gastric juice of subjects from a high-risk area for gastric cancer and the inhibition of N-nitrosamine formation by fruit juices. Eur J Cancer Prev 2: 25-36 (1993).

47. Levallois P, Ayotte P, Maanen JMS van, Gingras S, Desrosiers T, Dallinga JW, Zee J, Poirier G. Urinary excretion of volatile nitrosamines in non-smoking well-water users. Proc of the ISEE/ISEA Joint Conference 1998. Boston, Massachusetts, USA.

48. Fried M, Siegrist H, Frei R, Froehlich F, Duroux P, Thorens J, Blum A, Bille J, Gonvers JJ, Gyr K. Duodenal bacterial overgrowth during treatment in outpatients with omeprazole. Gut 35: 23-26 (1994).

49. Mirvish SS. Role of N-nitroso compounds (NOC) and N-nitrosation in etiology of gastric, esophageal, nasopharyngeal and bladder cancer and contribution to cancer of known exposures to NOC. Cancer Lett 93: 17-48 (1995).

50. Hatlebakk JG, Katz PO, Kuo B, Castell DO. Nocturnal gastric acidity and acid breakthrough on different regimens of omeprazole $40 \mathrm{mg}$ daily. Aliment Pharmacol Ther 12: 1235-1240 (1998).

51. Reh BD, DeBord DG, Butler MA, Reid TM, Mueller C, Fajen JM. O6-methylguanine DNA adducts associated with occupational nitrosamine exposure. Carcinogenesis 21: 29-33 (2000).

52. Blandizzi C, Gherardi G, Marveggio C, Natale G, Carigneni D, Del Tacca M. Mechanisms of protection by omeprazole against experimental gastric mucosal damage in rats. Digestion 56: 220-229 (1995).

\section{Appendix}

We studied the endogenous formation of nitrosamines in healthy volunteers, after nitrate intake at the ADI level, to gain insight in the risk of endogenous formation of these carcinogenic compounds (see Chapter 3). Urinary excretion of nitrosamines was measured as a reflection of endogenous formation of nitrosamines, that predominantly occurs in the stomach. We wanted to compare excretion of nitrosamines by healthy volunteers with urinary excretion of a group possibly at high risk of NOC formation. The selected group were patients with gastric disorders on long-term treatment with omeprazole, at high risk of endogenous NOC formation and gastric cancer. These patients had to be 
endoscopically examined for medical reasons, which created for us the opportunity to:

- study nitrosamine levels in gastric juice and compare these levels with urinary excretion of nitrosamines. Subsequently, the excretion of nitrosamines by patients at high risk of endogenous formation of NOC can be compared with urinary nitrosamine excretion by healthy volunteers after high nitrate intake.

- take gastric biopsies and isolate DNA from one of the target tissues of NOC.

The DNA was used to study alkylguanosine adducts and K-ras mutations, as biological markers of effects of intragastric exposure to NOC. This would provide information on the possible biological consequences of exposure to NOC. If DNA adduct levels could be related to urinary excretion of nitrosamines, this information could be translated to the study with healthy volunteers. However, the patients appeared not to be at high risk of endogenous formation of NOC, since no difference in gastric NOC levels was observed compared with a control group. Furthermore, no alkyl adducts could be detected in DNA isolated from gastric biopsies above the detection limit of 1 adduct $/ 10^{6}$ nucleotides. Recalculating the data in Chapter 3 shows an urinary NDMA excretion during days 1-3 and days 4-7 after nitrate intake at ADI level in combination with fish, of $4.9 \pm 2.8$ and $3.4 \pm 2.2 \mathrm{nmol} / \mathrm{mmol}$ creatinine, respectively. Urinary NDMA excretion in the patient group was $2.7 \pm 2.8 \mathrm{nmol} / \mathrm{mmol}$ creatinine, indicating that healthy subjects synthesized higher levels of NOC after high nitrate exposure than patients on long-term treatment with omeprazole. In conclusion, cancer risk extrapolation from patients at high risk for gastric cancer, to healthy volunteers with induced endogenous formation of NOC, based on urinary NOC excretion levels, appeared not possible. However, this study did answer the urgent clinical question about the safety of long-term treatment with proton pump inhibitors, regarding the risk of increased endogenous formation of carcinogenic NOC. 


\title{
Chapter 6
}

\section{Evidence for the lack of Helicobacter pylori-mediated formation of carcinogenic $\mathrm{N}$-nitrosamines}

\author{
I.T.M. Vermeer ${ }^{1}$ \\ M.M. Gerrits ${ }^{2}$ \\ E.J.C. Moonen \\ L.G.J.B. Engels ${ }^{3}$ \\ J.W. Dallinga' \\ J.C.S. Kleinjans \\ J.M.S. van Maanen \\ E.J. Kuipers \\ J.G. Kusters ${ }^{2}$
}

Submitted for publication

'Department of Health Risk Analysis and Toxicology, Maastricht University, P.O. Box 616, 6200 MD Maastricht, The Netherlands

2 Department of Medical Microbiology, School of Medicine, Free University, Amsterdam, The Netherlands

${ }^{3}$ Department of Gastroenterology, Maasland Hospital Sittard, The Netherlands

'Department of Gastroenterology, Free University Hospital, Amsterdam, The Netherlands 


\begin{abstract}
Helicobacter pylori infection causes chronic gastritis and intestinal metaplasia, and is a risk factor for the development of gastric cancer. N-nitroso compounds (NOC) are another risk factor for the development of gastric cancer in humans. Endogenous formation of NOC is catalyzed in acidic environment, and hence occurs predominantly in the acidic stomach (chemical nitrosation). At neutral pH, bacteria can catalyze formation of NOC. It has been reported that H. pylori has a low nitrosation capacity, but this statement was based on experiments with only a single H. pylori strain, and with a non-carcinogenic N-nitroso compound as end product. As $H$. pylori is a highly diverse bacterial species, it is reasonable to question the generality of this finding. In the present study, several genetically distinct $H$. pylori strains were tested for their capacity to form carcinogenic $\mathrm{N}$ nitrosamines. This may be an important contributing factor to the carcinogenicity of $\mathrm{H}$. pylori. Bacteria were grown both at neutral $\mathrm{pH}$ and at acidic $\mathrm{pH}$ in the presence of $0-1000 \mu \mathrm{M}$ morpholine and nitrite (in a 1:1 molar ratio). Both at neutral ( $\mathrm{pH} \mathrm{7)}$ and at acidic conditions ( $\mathrm{pH} 5$ and 3) there was no significant induction of nitrosomorpholine (NMOR) formation by any of the H. pylori strains. Incubation of Neisseria cinerea (as a positive control) with $500 \mu \mathrm{M}$ morpholine and $500 \mu \mathrm{M}$ nitrite, resulted in a significant increase in formation of NMOR, indicating that under the conditions used, bacterial catalyzation of NOC formation is observed. In conclusion, $H$. pylori do not induce formation of carcinogenic $\mathrm{N}$ nitrosamines in vitro. The reported weak nitrosation capacity of H. pylori is not sufficient to nitrosate the more difficultly nitrosatable secondary amines. These results imply that $H$. pylori infection is not a direct risk factor for formation of carcinogenic nitrosamines.
\end{abstract}




\section{Introduction}

Helicobacter pylori is a Gram-negative spiral bacterium, able to colonize the gastric mucosa at a low $\mathrm{pH}$. As a result of its urease activity, this bacterium has the capacity to create a local alkaline environment that protects it against gastric acid $(1,2)$. H. pylori infection has been identified as a major cause of chronic gastritis and intestinal metaplasia, which represent an increased risk for gastric cancer (35). The association between $H$. pylori and gastric cancer is considered to be so strong that $H$. pylori has been designated a Class I carcinogen (6). Figure 1 shows the proposed model for development of the intestinal type of gastric cancer (modified from Correa (7)).

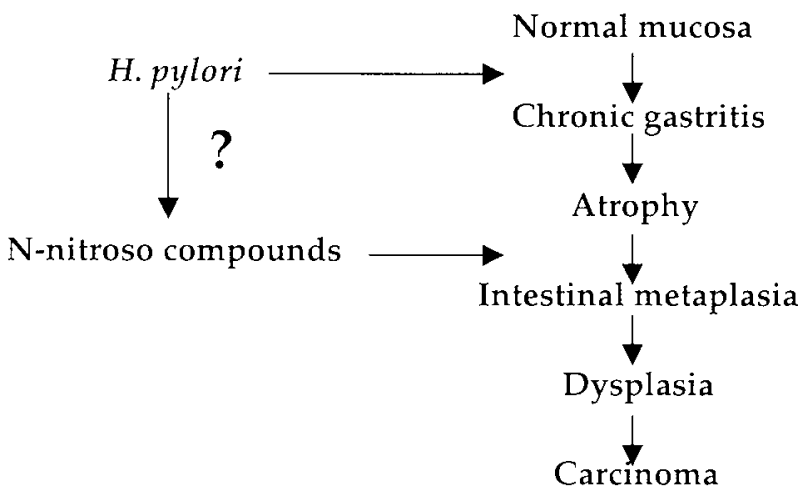

Figure 1. Proposed model for development of intestinal type gastric cancer, including the study hypothesis (modified from Correa 1992 (7)).

Figure 1 also indicated $\mathrm{N}$-nitroso compounds (NOC), which form another risk factor for gastric cancer. NOC are predominantly formed in the stomach at low $\mathrm{pH}$ as a result of chemical nitrosation of amines and amides. At neutral $\mathrm{pH}$, no chemical nitrosation occurs, but at this $\mathrm{pH}$ bacteria, particularly denitrifying bacteria, can catalyze the formation of NOC (8-13). Calmels et al. (14) suggested that bacterial cytochrome $\mathrm{cd}_{1}$-nitrite reductase is responsible for this enzymatic catalysis. In this respect, H. pylori is a special bacterium, given its capacity to colonize the acidic stomach. It was previously shown that $H$. pylori (cultured at $\mathrm{pH}$ 7) has a low nitrosation capacity (15). However, this conclusion is based on experiments with only a single $H$. pylori strain, and as this bacterium is a highly 
diverse species, the generality of this observation is questionable. In addition, the authors also restricted themselves to testing only the formation of the noncarcinogenic compound N-nitroso-4-(methylamino)antipyrine.

In recent years it has become clear that genetically different $H$. pylori strains differ in their pathogenic potential. Part of the strains contain the cag pathogenicity island, which encodes for several genes playing a role in enhanced inflammatory response $(16,17)$. The cagA gene (cytotoxin-associated gene) is considered to be a marker for the presence of the cag pathogenicity island, and is present in approximately $60 \%$ of the $H$. pylori strains. Compared to infection with $\operatorname{cag} A$ negative strains, infection with a $\operatorname{crg} A$ positive $H$. pylori strain is associated with an increased risk for development of atrophic gastritis and gastric cancer $(16,18,19)$.

The aim of the present study was to determine if the cancer risk associated with H. pylori infection is related to formation of carcinogenic N-nitrosamines, and if so, whether different $H$. pylori strains differ in nitrosating capacity. Therefore, we analyzed the nitrosation capacity of various $H$. pylori strains with and without the cagA pathogenicity island, using morpholine as a substrate for the bacterial formation of N-nitrosomorpoline (NMOR), which is a known carcinogen. Finally, we investigated whether the possible nitrosating capacity of $H$. pylori is $\mathrm{pH}$ dependent.

\section{Materials and methods}

\section{Culture conditions}

The different strains used are listed in Table I. Bacterial stock cultures were stored at $-80^{\circ} \mathrm{C}$ in brain heart infusion broth with $20 \%$ glycerol. All strains were cultured on Columbia agar plates (Oxoid, Basingstoke, Hampshire, England) supplemented with 7\% lysed, defibrinated horse blood (BioTrading Benelux BV, Mijdrecht, The Netherlands), 0.004\% tetrazolium chloride (Sigma, St. Louis, Mo), and $0.0025 \%$ of H. pylori selective supplement (Dent supplement (Oxoid)). The plates were incubated micro-aerobically $\left(5 \% \mathrm{O}_{2}, 10 \% \mathrm{CO}_{2}, 85 \% \mathrm{~N}_{2}\right)$ at $37^{\circ} \mathrm{C}$ for $2-3$ days.

\section{Incubations at $\mathrm{pH} 7$}

Bacteria harvested from one freshly grown confluent plate, were inoculated in 100 ml brucella broth (Difco, Detroit, Mich.) supplemented with 3\% newborn calf serum and $0.0025 \%$ Dent supplement $\left(\mathrm{BB}^{+}\right)$. The inoculum was incubated microaerobically for $24 \mathrm{~h}$ at $37^{\circ} \mathrm{C}$ with gentle shaking. At the start of the experiment, the overnight culture was split into $15-\mathrm{ml}$ portions and equimolar amounts of nitrite and morpholine (range $0-1000 \mu \mathrm{M}$ ) were added. Uninoculated $\mathrm{BB}^{+}$was used to 
determine background formation of NMOR. Bacterial growth was assessed by determination of the optical density $\left(O D_{6,0}\right)$ of the culture. After $48 \mathrm{~h}$ of incubation, a $10 \mathrm{ml}$ aliquot of the culture was collected, centrifuged to remove the bacteria, and the supernatant was alkalized by the addition of $100 \mu \mathrm{l}$ of $10 \mathrm{M}$ $\mathrm{NaOH}$ and subsequently stored at $-20^{\circ} \mathrm{C}$.

Viability of the H. pylori after incubation was determined by studying bacterial morphology on Gram-stained slides. Viability was expressed as percentage bacillary bacteria (coccoid morphology of $H$. pylori indicates cell death).

\section{Incubations at pH 5}

The bacteria harvested from one freshly grown confluent plate were inoculated in $100 \mathrm{ml} \mathrm{BB}$ (adjusted to $\mathrm{pH} 5$ with $\mathrm{HCl}$ ), and split into $15-\mathrm{ml}$ portions. The experiments at $\mathrm{pH} 5$ were similar to the experiments at $\mathrm{pH} 7$. The only difference was the incubation period: the cultures at $\mathrm{pH} 5$ were grown for $24 \mathrm{~h}$.

\section{Incubations at pH 3 (acid shock)}

Experiments with H. pylori were also performed at $\mathrm{pH} 3$. Since H. pylori does not grow at this $\mathrm{pH}$, the bacteria were first cultured on Columbia agar plates as described in the first paragraph. H. pylori harvested from one such plate were then resuspended in a small volume of PBS. The $\mathrm{OD}_{6,5}$ was adjusted to $1.0\left( \pm 6.7 \times 10^{8}\right.$ Colony Forming Units/ml) with PBS, pH 3. Nitrite and morpholine were added, and these cultures were incubated in a micro-aerobic atmosphere at $37^{\circ} \mathrm{C}$ for 1 or 3 h. Control incubations were performed without H. pylori. $\mathrm{NaOH}$ was added to the supernatants and bacterial morphology was studied as described above.

\section{Analysis of NMOR}

N-nitrosomorpholine (NMOR) was determined by gas chromatography-mass spectrometry (GC-MS) as previously described (27) with some modifications.

Five $\mathrm{ml}$ of the supernatant of the cultures were extracted with $1 \mathrm{ml}$ of dichloromethane. $0.5 \mu \mathrm{l}$ of the dichloromethane solution was injected into the GCMS system, consisting of an HP5890 Series II gas chromatograph (HewlettPackard, Avondale, Pennsylvania) and a Jeol SX102A mass spectrometer (Jeol Ltd., Tokyo). The molecular ions ( $\mathrm{M}^{*}$ ) were detected using a resolution of 1000 . Quantification was performed by a calibration curve, using a nitrosamine mixture for EPA method 8270 (Aldrich, Zwijndrecht, the Netherlands). The calibration curve was prepared in brucella broth by extraction of nitrosamines as the samples, adjusting for a possible loss of nitrosamines during work-up. The detection limit was $1 \mathrm{pg} / \mu 1$ dichloromethane solution. 
Statistical methods

Experiments were performed as independent duplicates. Results are presented as mean \pm standard deviation (SD). The non-parametric Mann-Whitney test was used to evaluate a possible formation of NMOR. A p-value $<0.05$ was considered significant.

\section{Results}

\section{Incubations at $\mathrm{pH} 7$}

As a positive control we used Neisseria cinerea DSM 4630 that has been shown to be a potent inducer of nitrosation of morpholine (28). After incubation of Neisseria cinerea with $500 \mu \mathrm{M}$ morpholine and $500 \mu \mathrm{M}$ nitrite, a significant increase in formation of NMOR was detected (Mann-Whitney, $\mathrm{p}=0.014$ ), compared with uninoculated $\mathrm{BB}^{+}$(Table 1).

Different $H$. pylori strains, including $\operatorname{cag} A^{+}$and $\operatorname{cag} A^{*}$ strains, were tested for nitrosating capacity at neutral $\mathrm{pH}$. The results are presented in Table 1 . The $H$. pylori strains were incubated at $\mathrm{pH} 7$ at a 1:1 molar ratio of morpholine:nitrite. The growth of $\mathrm{H}$. pylori is difficult to standardize in these experiments, since the growth rate of the different strains displays significant variability. The mean initial $\mathrm{OD}_{650}\left( \pm \mathrm{SD}\right.$ ) was $0.24 \pm 0.04$ (range 0.19-0.30), so the initial $\mathrm{OD}_{650}$ displayed only minor variation. After $48 \mathrm{~h}$ of incubation, the range in $\mathrm{OD}_{650}$ increased; the mean $\mathrm{OD}_{650}$ was $0.68 \pm 0.22$ (range 0.45-1.1). Nevertheless, it is safe to conclude that there was no significant effect of morpholine and nitrite on the growth rate of the different $H$. pylori strains. Also the viability of $H$. pylori was investigated. After $48 \mathrm{~h}$ of incubation, the percentage bacillary bacteria (as index of viability) ranged from $90-100 \%$, and the addition of morpholine and nitrite had no significant effect on the viability of H. pylori.

Incubations performed in the absence of bacteria (but with morpholine and nitrite present), show that after $48 \mathrm{~h}$ of incubation, some spontaneous formation of NMOR occurred (Table 1). Uninoculated $\mathrm{BB}^{+}$with $500 \mu \mathrm{M}$ morpholine:nitrite, and $1000 \mu \mathrm{M}$ morpholine:nitrite, resulted in NMOR concentrations of $0.33 \mu \mathrm{M}$ and $1.35 \mu \mathrm{M}$, respectively. Inoculation of $\mathrm{BB}^{-}$with Helicobacter strains did not significantly increase these background values. The data presented in Table 1 clearly indicate that neither the $\operatorname{cag} A^{+}$nor the $\operatorname{cag} A^{*} H$. pylori strains were capable to induce significant amounts of NMOR formation. 
Table 1. Formation of NMOR $(\mu \mathrm{M})$ by H. pylori and Neisseria cinerea at pH 7 (mean \pm SI)).

\begin{tabular}{|c|c|c|c|c|c|c|}
\hline \multirow[t]{2}{*}{ Strain } & \multirow[t]{2}{*}{ Ref. } & \multicolumn{5}{|c|}{$\begin{array}{l}\text { Concentrations of morpholine and nitrite }(\mu \mathrm{M}) \text { using a } 1: 1 \\
\text { molar ratio }\end{array}$} \\
\hline & & $0^{2}$ & $50^{3}$ & 100 & 500 & 1000 \\
\hline control $^{4}$ & & -5 & $\mathrm{ND}^{\prime}$ & $0.015 \pm 0.009$ & $0.33 \pm 0.10$ & $1.35 \pm 0.61$ \\
\hline Neisseria & $(20)$ & ND & $0.001 \pm 0.001$ & $0.041 \pm 0.004$ & $44.4 \pm 24.2^{3}$ & - \\
\hline
\end{tabular}

Mean of $\operatorname{cag} A^{+}$

$\begin{array}{lllllll}\text { strains } & & \text { ND } & 0.0002 \pm 0.0004 & 0.004 \pm 0.001 & 0.07 \pm 0.05 & 0.24 \pm 0.14 \\ \text { J99 } & (21) & \text { ND } & 0.0004 & 0.003 & 0.10 & - \\ 26695 & (22) & \text { ND } & \text { ND } & 0.004 \pm 0.001 & 0.17 \pm 0.07 & - \\ \text { ATCC 43504 } & (23) & \text { ND } & - & 0.004 \pm 0.001 & 0.08 \pm 0.05 & 0.12^{*} \\ 84183 & (24) & \text { ND } & - & - & 0.04 \pm 0.02 & 0.19 \pm 0.09 \\ \text { Hpk 5 } & (24) & \text { ND } & - & - & 0.04 \pm 0.01 & 0.18 \pm 0.04 \\ 4 A & (25) & \text { ND } & - & - & 0.06 \pm 0.03 & 0.32 \pm 0.10 \\ \text { 6A } & (25) & \text { ND } & - & - & 0.07 \pm 0.03 & 0.41 \pm 0.23 \\ 7 A & (25) & \text { ND } & - & - & 0.03 \pm 0.001 & 0.16 \pm 0.06\end{array}$

Mean of $\operatorname{cag} A^{-}$

strains

Hpk 1

$\begin{array}{lll} & \text { ND } & - \\ \text { (24) } & \text { ND } & - \\ \text { (25) } & \text { ND } & -\end{array}$

-

$0.05 \pm 0.03$

$0.25+0.13$

$3 \mathrm{~A}$

$-\quad 0.05 \pm 0.04$

$0.27 \pm 0.19$

$-$

$0.05 \pm 0.02$

$0.24 \pm 0.12$

\begin{abstract}
'literature reference number, 'growth control: brucella broth' with bacteria, without morpholine and nitrite, "incubation with $50 \mu \mathrm{M}$ morpholine $+50 \mu \mathrm{M}$ nitrite, "negative control: $\mathrm{BB}$ ' with morpholine and nitrite, without bacteria, "incubation not performed, "ND: Non Detectable, "significantly increased compared with the negative control (Mann-Whitney, $p=0.014$ ), "single measurement.
\end{abstract}

Incubations at $\mathrm{pH} 5$ and 3

Compared to the $\mathrm{pH} 7$ experiments, the experiments at $\mathrm{pH} 5$ and $\mathrm{pH} 3$ were performed according to a slightly different protocol, since both growth rate and viability of $H$. pylori are affected by the changes in $\mathrm{pH}$. Culturing $H$. pylori in fluid media at $\mathrm{pH} 5$ is more difficult than at $\mathrm{pH} 7$. This is reflected by the percentage bacillary bacteria, ranging from $50-95 \%$ after $24 \mathrm{~h}$, and by the growth rate of the bacteria. The mean initial $\mathrm{OD}_{6,0}$ was $0.12 \pm 0.03$. After $24 \mathrm{~h}$, the mean $\mathrm{OD}_{6,50}$ was $0.13 \pm 0.03$. Incubations of $H$. pylori strains with morpholine and nitrite at pH 5 
showed a higher background of NMOR formation in the negative control (uninoculated $\mathrm{BB}^{+}$), but also at $\mathrm{pH} 5$ there is no additional NMOR formation by the different $H$. pylori strains (Table 2).

Table 2. Formation of NMOR $(\mu \mathrm{M})$ by H. pylori at pH 5 (mean $\pm \mathrm{SD})$.

\begin{tabular}{|c|c|c|c|}
\hline \multirow[t]{2}{*}{ Strain } & \multicolumn{3}{|c|}{ Concentration of morpholine and nitrite $(\mu \mathrm{M})$} \\
\hline & $0^{1}$ & 500 & 1000 \\
\hline control ${ }^{2}$ & - & $5.36 \pm 0.93$ & $35.8 \pm 1.24$ \\
\hline J99 & $\mathrm{ND}^{3}$ & $1.49 \pm 0.11$ & $16.0 \pm 0.02$ \\
\hline 26695 & ND & $2.86 \pm 0.15$ & $25.6 \pm 0.92$ \\
\hline ATCC 43504 & ND & $3.49 \pm 1.26$ & $24.0 \pm 3.18$ \\
\hline $\begin{array}{l}\text { Mean of all } \\
\text { strains }\end{array}$ & ND & $2.83 \pm 1.20$ & $22.4 \pm 4.52$ \\
\hline
\end{tabular}

'growth control: brucella broth' with bacteria, without morpholine and nitrite 'negative control: $\mathrm{BB}$ ' with morpholine and nitrite, without bacteria

${ }^{3} N D$ : Non Detectable

At $\mathrm{pH} 3$, H. pylori can survive for a short period of time, but no growth occurs. Results of the experiments at pH 3 are presented in Table 3 . Again, none of the $H$. pylori strains showed formation of NMOR. Cell viability after incubation was between 90 and $100 \%$.

\section{Discussion}

H. pylori is a human pathogen, which causes chronic gastritis and intestinal metaplasia, which process can ultimately lead to gastric cancer (3-6). Another risk factor for gastric cancer is presented by the intragastric formation of NOC, which induce the formation of DNA-adducts. It has been reported that bacteria can catalyze formation of $\mathrm{NOC}$ at neutral $\mathrm{pH}$ (8-13). H. pylori may indirectly be involved in formation of NOC via three mechanisms. Firstly, H. pylori elicits an inflammatory response resulting in recruitment and subsequent activation of polymorphonuclear leukocytes and macrophages $(29,30)$. These inflammatory cells are capable of nitrosamine formation via production of nitric oxide $(31,32)$. 
Secondly, H. pylori infection causes chronic gastritis, leading to atrophy and hypochlorhydria (3). As a consequence of the increasing pH in the stomach, nitrosating bacteria are able to proliferate in the gastric juice and produce NOC (813). Thirdly, H. pylori infection reduces the ascorbic acid concentration in the stomach, while ascorbic acid inhibits formation of NOC (3).

Table 3. Formation of NMOR $(\mu \mathrm{M})$ by H. pylori at $\mathrm{pH} 3$ (mean \pm SD), after incubation for 1 or $3 \mathrm{~h}$ with $500 \mu \mathrm{M}$ morpholine and $500 \mu \mathrm{M}$ nitrite.

\begin{tabular}{lll}
\hline Strain & \multicolumn{2}{c}{ Incubation time } \\
& $1 \mathrm{~h}$ & $3 \mathrm{~h}$ \\
\hline control $^{2}$ & $0.46 \pm 0.047$ & $0.76 \pm 0.20$ \\
$\mathrm{~J} 99$ & $0.31 \pm 0.100$ & $0.65 \pm 0.18$ \\
26695 & $0.14 \pm 0.036$ & $0.36 \pm 0.01$ \\
ATCC 43504 & $0.12 \pm 0.028$ & $0.36 \pm 0.13$ \\
NCTC $11638^{2}$ & $0.11 \pm 0.025$ & $0.31 \pm 0.41$
\end{tabular}

Mean of all

strains

$0.16 \pm 0.090$

$0.41 \pm 0.22$

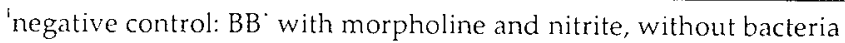
${ }^{2} \operatorname{cog} A$ strain, literature reference (26)

In addition to these indirect effects on NOC formation, there may also be a direct effect of H. pylori. The study performed by Ziebarth et al. (15) with one $H$. pylori strain, indicated that $H$. pylori can directly catalyze nitrosation of metamizole into the non-carcinogenic N-nitroso-4-(methylamino)antipyrene. Furthermore, taking into account the genetic and phenotypic diversity of $H$. pylori, more than one $H$. pylori strain has to be tested before making a general statement on the nitrosating capacity of $H$. pylori.

In addition, we investigated whether $H$. pylori can also be directly involved in formation of carcinogenic NOC. We therefore studied whether there is a difference in nitrosating capacity between the various strains. The results presented in Table 1, show that the positive control Neisseria cineren did catalyze the nitrosation reaction, indicating that our test method is useful for studying bacterially catalyzed formation of $\mathrm{N}$-nitrosamines. The diversity of H. pylori is already evident by only observing differences in bacterial growth rates after $48 \mathrm{~h}$ 
of incubation. However, neither fast nor slowly growing $\%$ pylori strains were capable of formation of NMOR at $p H I 7$, after incubation with nitrite and morpholine in concentrations of maximally $1 \mathrm{mM}$. These experiments were performed at $\mathrm{pH} 7$, because this is the optimum $\mathrm{pH}$ to culture H. pylori.

In the stomach, the $\mathrm{pH}$ gradient ranges from about 1.3 in the lumen to almost 7 in the vicinity of the epithelial cells (33). The experiments performed at $\mathrm{pH} 5$, therefore more closely reflect the situation within the mucus layer of the stomach close to the gastric epithelial cells, the preferred niche of $H$, pylori. However, as shown in Table 2, we did not detect any formation of NMOR after incubation of the different $H$. pylori strains at $\mathrm{pH} 5$. Background formation of NMOR in the uninoculated cultures was higher in experiments at pHI 5 compared to experiments at $\mathrm{pH} \mathrm{7,} \mathrm{because} \mathrm{at} \mathrm{pH} 5$ more chemical nitrosation occurred (the optimum $\mathrm{pH}$ for chemical nitrosation of morpholine is $\mathrm{pH} 3$ (34)). After $24 \mathrm{~h}$ of incubation with nitrite and morpholine, cell viability had significantly decreased. This was most pronounced at the highest concentration of nitrite and morpholine $(1 \mathrm{mM})$. This is probably due to the high nitrite concentration, since nitrite has anti-bacterial activity against $H$. pylori at low pH (35). However, a sufficient amount of $H$. pylori was still viable and able to exert possible nitrosating capacity.

At pH 3, a high metabolic activity is expected, since at low $\mathrm{pH}$, H. pylori has to use its high urease activity to create an alkaline environment. This may also be of influence on the enzymatic nitrosation capacity. The incubation periods were relatively short, because $H$. pylori cannot survive at low $\mathrm{pH}$ in fluid culture media longer than a few hours. However, also at this $\mathrm{pH}$, there was no significant increase of NMOR formation by $H$. pylori.

The nitrosating capacity of $H$. pylori has been investigated before, using the medicinal drug metamizole as nitrosatable substrate (15). In the study of Ziebarth et al. (15), the H. pylori strain DSM 4867 (= ATCC43504) was compared with Campylobacter jejuni and Neisseria cinerea. H. pylori showed a low nitrosating capacity, about 30-100 times lower than Neisserin. Metamizole is a readily nitrosatable substrate, yielding about 30 times more nitrosated product than morpholine at equivalent molar incubation concentrations (15). The results of the present study indicate that the weak nitrosating capacity of $H$. pylori as reported by Ziebarth et al. (15), is not sufficient to nitrosate the less readily nitrosatable precursors like the secondary amines. We therefore conclude that $H$. pylori does not induce the formation of carcinogenic N-nitrosamines in vitro.

Also, no $\mathrm{pH}$ dependent difference in nitrosating capacity of $H$. pylori was observed. Neither $\operatorname{cag} A^{-}$nor $\operatorname{cag} A^{-} H$. pylori strains are able to nitrosate morpholine in vitro, while morpholine is one of the most readily nitrosated secundary amines. In summary, the cancer risk associated with $H$. pylori infection, can not be explained by direct induction of intragastric synthesis of NOC. 


\section{References}

1. Dunn BE. Pathogenic mechanisms of Helicobacter pylori. Gastroentero. Clin North Am 22: 43-57 (1993).

2. Goodwin CS, Worsley BW. Microbiology of Helicobacter pylori. Gastroenterol Clin North Am 22: 5-19 (1993).

3. Goldstone AR, Quirke P, Dixon MF. Helicobacter pylori infection and gastric cancer. J Pathol 179: 129-137 (1996).

4. Kuipers EJ. Review article: exploring the link between Helicobacter pylori and gastric cancer. Aliment Pharmacol Ther 13: 3-11 (1999).

5. McFarlane GA, Munro A. Helicobacter pylori and gastric cancer. Br I Surg 84: 11901199 (1997).

6. IARC Working Group on the evaluation of carcinogenic risks to humans. Schistosomes, liver flukes and Helicobacter pylori. IARC Monographs on the evaluation of carcinogenic risk to humans 61, 177-241 (1994).

7. Correa P. Human gastric carcinogenesis: a multistep and multifactorial process First American Cancer Society award lecture on cancer epidemiology and prevention. Cancer Res 52: 6735-6740 (1992).

8. Suzuki K, Mitsuoka T. N-nitrosamine formation by intestinal bacteria. In: O'Neill I, Borstel RC von, Miller CT, Long J, Bartsch H. (ed.) N-Nitroso Compounds: Occurrence, Biological Effects and Relevance to Human Cancer. IARC Sci. Publ., International Agency for Research on Cancer, Lyon, No 57, 275-281 (1984).

9. Calmels S, Ohshima H, Rosenkranz H, McCoy E, Bartsh H. Biochemical studies on the catalysis of nitrosation by bacteria. Carcinogenesis 8: 1085-1088 (1987).

10. Massey RC, Key PE, Mallett AK, Rowland IR. An investigation of the endogenous formation of apparent total $\mathrm{N}$-nitroso compounds in conventional microflora and germ-free rats. Fd Chem Toxic 26: 595-600 (1988).

11. Leach SA, Thompson M, Hill M. Bacterially catalysed N-nitrosation reactions and their relative importance in the human stomach. Carcinogenesis 8: 1907-1912 (1987).

12. Hill MJ, Hawksworth $G$. Bacterial production of nitrosamines in vitro and in vivo. In: Bogovski P, Preussman R, Walker EA. (ed.) N-Nitroso Compounds. Analysis and formation. IARC Sci. Publ. International Agency for Research on Cancer, Lyon, No 3 , pp. 116-121 (1972).

13. Calmels $\mathrm{S}$, Ohshima $\mathrm{H}$, Bartsch $\mathrm{H}$. Nitrosamine formation by denitrifying and nondenitrifying bacteria: implication of nitrite reductase and nitrate reductase in nitrosation catalysis. J Gen Microbiol 134: 221-226 (1988).

14. Calmels S, Ohshima H, Henry Y, Bartsch H. Characterization of bacterial cytochrome $\mathrm{cd}_{1}$-nitrite reductase as one enzyme responsible for catalysis of nitrosation of secondary amines. Carcinogenesis 17: 533-536 (1996).

15. Ziebarth D, Spiegelhalder B, Bartsch H. N-nitrosation of medicinal drugs catalysed by bacteria from human saliva and gastro-intestinal tract, including Helicobacter pylori. Carcinogenesis 18: 383-389 (1997).

16. Gumn MC, Stephens JC, Stewart JAD, Rathbone BJ, West KP. The significance of $\operatorname{cag} A$ and racA subtypes of Helicobacter pylori in the pathogenesis of inflammation and peptic ulceration. J Clin Pathol 51: 761-764 (1998).

17. Blaser MJ. Hypothesis: The changing relationships of Helicobacter pylori and humans: implications for health and disease. J Infect Dis 179: 1523-1530 (1999). 
18. Blaser MJ, Perez-Perez GI, Kleanthous U, Cover TL, l'eek RM, Chyou HI, Stemmermann GN, Nomura A. Infection with Helicobacter mylori strains possossing $\operatorname{cag} A$ is associated with an increased risk of developing adenocarcinoma of the stomach. Cancer Re's 55: 2111-2115 (1995).

19. Crabtree JE, Farmery SM. Helicobacter pylori and gastric mucosal cytokines: evidence that cagA-positive strains are more virulent. Lab Ino'st 73: 742-745 (1995).

20. Skerman VBD, McGowan V, Sneath PHA. Approved lists of bacterial names. Int I Syst Bacteriol 30: 225-420 (1980).

21. Alm RA, Ling LS, Moir DT, King BL, Brown ED, Doig PC, Smith DR, Noonan B, Guild BC, et al. Genomic-sequence comparison of two unrelated isolates of the human gastric pathogen Helicobacter pylori. Nature 397: 176-180 (1999).

22. Tomb JF, White O, Kerlavage AR, Clayton RA, Sutton GG, Fleischmann RD, Ketchum KA, Klenk HP, Gill S, et al. The complete genome sequence of the gastric pathogen Helicobacter pylori. Nature 388: 539-547 (1997).

23. Marshall BJ, Goodwin CS. Revised nomenclature of Compylobacter pyloridtis. Int I Syst Bacteriol 37: 68 (1987).

24. Kuipers EJ, Israel DA, Kusters JG, Blaser MJ. Evidence for conjugation-like mechanism of DNA transfer in Helicobacter pylori. J Bacteriol 180: 2901-2905 (1998).

25. Kuipers EJ, Israel DA, Kusters JG, Gerrits MM, Weel J, Van der Ende A, Van der Hulst RWM, Wirth HP, Höök-Nikanne J, Thompson SA, Blaser MJ. Quasispecies development of Helicolnater pylori observed in paired isolates obtained years apart from the same host. J Infect Dis 181: 273-282 (2000).

26. Akopyants NS, Jiang Q, Taylor DE, Berg DE. Corrected identity of isolates of Helicobacter pylori reference strain NCTC11637. Helicobacter 2: 48-52 (1997).

27. Vermeer ITM, Pachen DMFA, Dallinga JW, Kleinjans JCS, Van Maanen JMS. Volatile $\mathrm{N}$-nitrosamine formation after intake of nitrate at the ADI level in combination with an amine-rich diet. Environ Health Perspect 106: 459-463 (1998).

28. Calmels S, Dalla Venezia N, Bartsch H. Isolation of enzyme catalysing nitrosamine formation in Pseudomonas aeruginosa and Neisseria mucosa. Biochem Biophys Re's Comm 171: 655-660 (1990).

29. Shapiro KB, Hotchkiss JH. Induction of nitric oxide synthesis in murine macrophages by Helicobacter pylori. Cancer Lett 102: 49-56 (1996).

30. Carreras MC, Pargament GA, Catz SD, Poderoso JJ, Boveris A. Kinetics of nitric oxide and hydrogen peroxide production and formation of peroxynitrite during the respiratory burst of human neutrophils. FEBS Lett 341: 65-68 (1994).

31. Grisham MB, Ware K, Gilleland HE Jr., Gilleland LB, Abell CL, Yamada T. Neutrophil-mediated nitrosamine formation: role of nitric oxide in rats. Gastroniterology 103: 1260-1266 (1992).

32. Miwa M, Stuehr DJ, Marletta MA, Wishnok JS, Tamenbaum SR. Nitrosation of amines by stimulated macrophages. Carcinogenenesis 8: 955-958 (1987).

33. Del Valle J, Cohen H, Laine L, Scheiman JM. Acid peptic disorders (chapter 64). In: Yamada T, Alpers DH, Laine L, Owyang C, Powell DW. (Ed.) Tixthook of gastro'nterology. Lippincott, Williams \& Wilkins, Philadelphia (1999).

34. Mirvish SS. Kinetics of N-nitrosation reactions in relation to tumorigenesis experiments with nitrite plus amines or ureas. In: Bogovski P, Preussman R, Walker EA. (ed.) N-Nitroso Compounds. Analysis and formation. IARC Sci. Publ., International Agency for Research on Cancer, Lyon, No 3, pp. 104-108 (1972). 
35. Dykhuizen RS, Fraser A, McKenzie H, Golden M, Leifert C, Benjamin N. Helicobacter pylori is killed by nitrite under acidic conditions. Gut 42: 334-337 (1998). 


\section{Chapter 7}

\section{Neutrophil-mediated formation of carcinogenic $\mathrm{N}$-nitroso compounds in an in vitro model for intestinal inflammation}

I.T.M. Vermeer

L.Y. Henderson

E.J.C. Moonen

L.G.J.B. Engels*

J.W. Dallinga

J.C.S. Kleinjans

J.M.S. van Maanen

Submitted for publication

Department of Health Risk Analysis and Toxicology, Maastricht University, P.O. Box 616, 6200 MD Maastricht, The Netherlands *Department of Gastroenterology, Maaslandziekenhuis Sittard, The Netherlands 


\section{Abstract}

Chemical nitrosation in the stomach is considered to represent the major source of endogenous nitrosation. However, also formation of nitrosamines by intestinal bacteria and cultured macrophages has been reported. Activated macrophages produce nitric oxide (NO), resulting in formation of $\mathrm{N}_{2} \mathrm{O}_{3}$ and $\mathrm{N}_{2} \mathrm{O}_{4}$, which are potent nitrosating agents. Chronic inflammation in the colon is associated with increased risk of colorectal cancer, which may be caused by carcinogenic Nnitroso compounds formed by inflammatory cells.

As in vitro model for intestinal inflammation, we designed a coincubation system with human colon cells (Caco-2 cells) and activated human neutrophils (PMN), as important immunoreactive cells, and investigated whether carcinogenic Nnitrosamines and $\mathrm{N}$-nitrosamides could be formed. For this purpose, dimethylamine, morpholine and methylurea were added to the coincubations as nitrosatable precursors, which are known to produce carcinogenic $\mathrm{N}$-nitroso compounds.

Incubations of pure NO with dimethylamine and morpholine showed that NOmediated formation of nitrosodimethylamine (NDMA) and nitrosomorpholine (NMOR) was possible under the incubation conditions. During the coincubations of activated human PMN and Caco- 2 cells, 0.34 nmol nitrite $/ 10^{6}$ PMN was produced. Addition of $5 \mathrm{mM}$ morpholine resulted in a significantly increased NMOR formation of $4.2 \mathrm{nM}$ after a $3 \mathrm{~h}$ incubation. However, no detectable amounts of NDMA and methylnitrosourea (MNU) were formed in the coincubation system.

These results suggest that activated human neutrophils are able to synthesize carcinogenic N-nitrosamines, e.g. NMOR, which implies a risk of colon carcinogenesis during chronic inflammation. However, levels of NOC probably will be low in situ, suggesting that also other factors are contributing to the association between chronic inflammation and colon cancer risk. 


\section{Introduction}

Endogenous formation of N-nitroso compounds (NOC) can occur in the acidic stomach resulting from a chemical reaction between nitrosating agents and amines or amides. Although the stomach is considered to be the most important site for endogenous nitrosation, other sources may be present in the body. For example, nitrosamine formation by intestinal bacteria has been reported $(1,2)$. Furthermore, inflammatory cells in organs with chronic infection or inflammation produce nitric oxide (NO), which can lead to nitrosation of amines (3). It has been shown that cultured macrophages activated by lipopolysaccharide (LPS) and interferon- $\gamma$, produce nitrite, nitrate and nitrosamines (4-6). One study has shown that also inflammatory neutrophils harvested by peritoneal lavage from rats, are capable of producing nitrosamines (7). Figure 1 presents a schematic view of the suggested mechanism: L-arginine is converted to L-citrulline by inducible nitric oxide synthase (iNOS) in polymorphonuclear leukocytes (PMN), thereby generating $\mathrm{NO}$. $\mathrm{NO}$ reacts with oxygen to form $\mathrm{N}_{2} \mathrm{O}_{3}$ and $\mathrm{N}_{2} \mathrm{O}_{4}$, which are potent nitrosating agents. The main end product of these reactions in a neutral aqueous solution is nitrite (8).

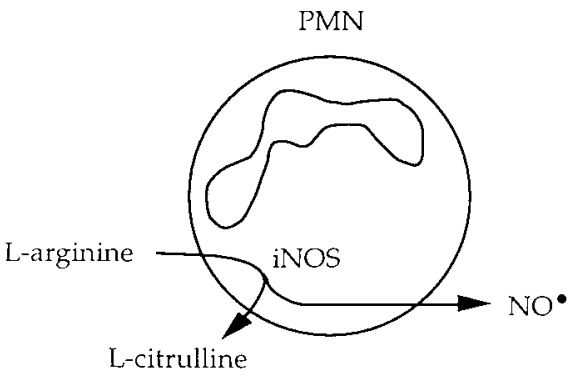

$$
\begin{aligned}
& 2 \mathrm{NO}^{\bullet}+\mathrm{O}_{2}+-2 \mathrm{NO}_{2}^{\bullet} \\
& \mathrm{NO}_{2}^{\bullet}+\mathrm{NO}^{\bullet}-\mathrm{N}_{2} \mathrm{O}_{3} \\
& \mathrm{~N}_{2} \mathrm{O}_{3}+\mathrm{H}_{2} \mathrm{O} \\
& 2 \mathrm{NO}_{2} \mathrm{~N}^{-}-2 \mathrm{NO}_{2}^{-}+2 \mathrm{H}^{+} \\
& \mathrm{N}_{2} \mathrm{O}_{4}+\mathrm{H}_{2} \mathrm{O}-\mathrm{N}_{2} \mathrm{O}_{4} \\
& -\mathrm{NO}_{2}^{-}+\mathrm{NO}_{3}^{-}+2 \mathrm{H}^{+}
\end{aligned}
$$

Formation of $\mathrm{N}$-nitrosamines:

$$
\begin{array}{ll}
\mathrm{N}_{2} \mathrm{O}_{3}+\mathrm{R}_{2} \mathrm{NH} & -\mathrm{R}_{2} \mathrm{~N}-\mathrm{NO}+\mathrm{HNO}_{2} \\
\mathrm{~N}_{2} \mathrm{O}_{4}+\mathrm{R}_{2} \mathrm{NH} & -\mathrm{R}_{2} \mathrm{~N}-\mathrm{NO}+\mathrm{HNO}_{3}
\end{array}
$$

Figure 1: Schematic view of PMN activation, generation of nitrosating agents and of $\mathrm{N}$ nitrosamines.

Results of several studies suggest that chronic inflammation in the colon, e.g. ulcerative colitis, is associated with an increased risk of colorectal cancer (913). Roediger et al. (14) hypothesized that nitrite production by inflammatory cells, such as neutrophils, in combination with amine production by bacteria, can 
possibly result in formation of carcinogenic NOC, which may be associated with the reported colon cancer risk in patients with ulcerative colitis.

The objective of this study was to design an in vitro model for chronic inflammation in the human colon, consisting of transformed colon epithelial cells (Caco-2) and freshly isolated human neutrophils. In this model, we investigated whether the PMN could synthesize carcinogenic NOC, after stimulation with phorbol-12-myristate-13-acetate (PMA) and addition of dimethylamine, morpholine or methylurea as the relevant nitrosatable precursors. It was furthermore analyzed whether the synthesized NOC could induce alkyl adducts in the Caco-2 cells, since DNA alkylation can be regarded as a first event in the process of carcinogenesis.

\section{Materials and methods}

Experiments with $\mathrm{NO}^{\circ}$ gas

To determine whether formation of NOC under chosen incubation conditions was possible after exposure of secondary amines to $\mathrm{NO}^{\circ}$, dimethylamine (DMA) and morpholine (MOR) were incubated with $\mathrm{NO}^{\circ}$, derived from a gas cylinder. Minimal Essential Medium (MEM) was deoxygenated with $\mathrm{N}_{2}$ gas. The medium was subsequently purged with $\mathrm{NO}^{\circ}$ gas for $30 \mathrm{~s}$, to create a solution saturated with $\mathrm{NO}^{\circ}$. A saturated solution contains about $4.6 \mathrm{ml} \mathrm{NO} / 100 \mathrm{ml}$ medium, corresponding to $2 \mathrm{mM} \mathrm{NO}^{\circ}(15)$. $\mathrm{NO}^{\circ}$ solution was added to $\mathrm{MEM}$ (of $37^{\circ} \mathrm{C}$ ) with $500 \mu \mathrm{M}$ DMA or $500 \mu \mathrm{M} \mathrm{MOR}$, in a final concentration of $10 \mu \mathrm{M}$. This mixture was incubated at $37^{\circ} \mathrm{C}$ for $10 \mathrm{~min}$. After $10 \mathrm{~min}, 50 \mu \mathrm{l} 10 \mathrm{M} \mathrm{NaOH}$ were added to the mixture $(5 \mathrm{ml})$ for the stabilization of NDMA and NMOR.

\section{Cell culture and coincubations}

Caco-2 cells were obtained from the American Type Culture Collection (Manassas, VA), and were used at passage no. $20-70$. The cells were grown at $37^{\circ} \mathrm{C}$ in Eagle's MEM with Earle's BSS and glutamax-I, supplemented with 20\% heatinactivated FBS, $0.1 \mathrm{mM}$ non-essential amino acids, $1.0 \mathrm{mM}$ sodium pyruvate, $1 \%$ penicillin-streptomycin solution and $25 \mathrm{mM}$ Hepes (all purchased from Gibco$\mathrm{BRL}$ ). PMN were freshly isolated from the blood of a healthy male volunteer as described previously (16). Cell number was determined and trypan blue was used to assess cell viability. Cell viability was $>97 \%$ and, after staining with Diff Quick, differential counts showed that $>98 \%$ of the isolated cells were PMN.

Coincubations were performed with confluent monolayers of Caco-2 cells grown in $25 \mathrm{~cm}^{2}$ culture flasks, and isolated PMN in a 1:10 ratio of Caco-2 and PMN, reflecting a severe inflammation. As nitrosatable precursors, DMA, MOR or methylurea $(\mathrm{MU})$ were added in different concentrations. PMN were activated 
with $100 \mathrm{ng} / \mathrm{ml}$ PMA. Caco-2 cells $\left( \pm 2.5 \times 10^{6}\right.$ cells $/$ flask) and PMN $\left(2.5 \times 10^{7}\right.$ cells) were coincubated with DMA, MOR or MU for $1 \mathrm{~h}$ or $3 \mathrm{~h}$ at $37^{\circ} \mathrm{C}$. After the incubation, $50 \mu \mathrm{l} 10 \mathrm{M} \mathrm{NaOH}$ were added to the supernatant $(5 \mathrm{ml})$ of the coincubations for the stabilization of nitrite and $\mathrm{N}$-nitroso compounds. Possible cytotoxicity of PMN, PMA, dimethylamine, morpholine and methylurea to Caco-2 cells was determined by the MTT colometric assay according to Mosmann (17).

\section{Nitrite analysis}

NO release from the PMN was assessed by determination of the nitrite concentration in the supernatant of the coincubations, using the Griess reaction. To $400 \mu \mathrm{l}$ of supernatant, $66.7 \mu \mathrm{l}$ of $0.2 \%$ sulfanilamide in $3.7 \% \mathrm{HCL}$ and $66.7 \mu \mathrm{l}$ of $16 \% \mathrm{HCL}$ were added. After $5 \mathrm{~min}$ at room temperature, $13.3 \mu 1$ of $0.125 \% \mathrm{~N}-1$ naphthylethylenediamine dihydrochloride were added. This mixture was incubated for $10 \mathrm{~min}$ at room temperature. Finally, $267 \mu \mathrm{l}$ of milliQ water were added and absorbance was measured at $543 \mathrm{~nm}$. Nitrite concentration was quantified from a standard curve using potassium nitrite as standard.

\section{Analysis of NDMA and NMOR}

NDMA and NMOR were determined by gas chromatography-mass spectrometry (GC-MS) as previously described (18) with some modifications.

$5 \mathrm{ml}$ of the reaction mixtures of the experiments with $\mathrm{NO}^{\circ}$ gas or $4.5 \mathrm{ml}$ of the supernatant of the coincubations, were extracted with $1 \mathrm{ml}$ of dichloromethane. $0.5 \mu \mathrm{l}$ of the dichloromethane solution was injected into the GC-MS system, consisting of an HP5890 Series II gas chromatograph (Hewlett-Packard, Avondale, Pennsylvania) and a Jeol SX102A mass spectrometer (Jeol Ltd., Tokyo). The molecular ions $\left(\mathrm{M}^{+}\right.$.) were detected using a resolution of 1000 . Quantification was performed by a calibration curve for each of the two nitrosamines, using a nitrosamine mixture for EPA method 8270 (Aldrich, Zwijndrecht, The Netherlands). The calibration curves (in MEM) were analyzed comparably to the samples, adjusting for a possible loss of nitrosamines during work-up. The detection limit for NDMA and NMOR was $1 \mathrm{pg} / \mu$ l of dichloromethane solution.

DNA isolation and analysis of N7-alkylguanosine adducts by immunoslot blot assay After incubation, the supernatant was removed and $5 \mathrm{ml}$ cold MEM were added to the culture flasks. PMN were washed off completely (as determined by microscopic examination) and the Caco-2 cells were harvested by gently scraping. DNA was isolated from the Caco-2 cells as previously described (19). Briefly, the cells were lysed in NEP/SDS solution (75 $\mathrm{mM} \mathrm{NaCl}, 25 \mathrm{mM}$ EDTA, $50 \mu \mathrm{g} / \mathrm{ml}$ proteinase $\mathrm{K}$ and $1 \%$ SDS). The homogenate was extracted with 1 volume of phenol, phenol/chloroform/isoamyl alcohol (25:24:1) and chloroform/isoamylalcohol (24:1), respectively. After DNA precipitation, RNA was removed by 
incubation with RNase A and RNase T1. After a second extraction with chloroform/isoamylalcohol (24:1), DNA was precipitated again.

DNA was dissolved in $10 \mathrm{mM} \mathrm{KH_{2 }} \mathrm{PO}_{4}-\mathrm{KOH}, \mathrm{pH} 7.0$, to a final concentration of $50 \mu \mathrm{g} / \mathrm{ml}$. The DNA was sonicated for $5 \mathrm{~s}$. Ring-opening of N7alkylguanine adducts was induced as follows: per $200 \mu \mathrm{l}$ of DNA solution, $4.7 \mu \mathrm{l}$ of $3 \mathrm{M} \mathrm{NaOH}$ were added followed by incubation for $30 \mathrm{~min}$ at $37^{\circ} \mathrm{C}$. The solution was neutralized by addition of $6 \mu \mathrm{l}$ of $1 \mathrm{M} \mathrm{KH}_{2} \mathrm{PO}_{4}$ and $15 \mu \mathrm{l}$ of $1 \mathrm{M} \mathrm{HCL}$ until pH 7.4. After addition of $275 \mu \mathrm{l} \mathrm{PBS}$ the sample was incubated for $5 \mathrm{~min}$ at $100^{\circ} \mathrm{C}$ and for $10 \mathrm{~min}$ at $0^{\circ} \mathrm{C}$. Finally, $500 \mu \mathrm{l}$ of $2 \mathrm{M} \mathrm{NH}_{4} \mathrm{AC}$ were added and the DNA concentration was determined spectrophotometrically. DNA alkylation was determined by the immunoslot blot assay and performed as described by Van Delft et al. (20) with some modifications. The nitrocellulose filter with the DNA samples was heated at $80^{\circ} \mathrm{C}$ for $1 \mathrm{~h}$. The filter was incubated overnight in $0.5 \times \mathrm{PBS}$, $0.1 \%$ Tween-20, $0.5 \%$ milk powder and 20,000-fold diluted first antibody N7E-026 (a gift from Van Delft). This monoclonal antibody specifically recognizes ringopened N7-methylguanosine and N7-ethylguanosine adducts (21). After washing, the filter was incubated for $1 \mathrm{~h}$ with a 10,000-fold dilution of the second antibody RAM-PO (Dako, Denmark) in PBS, 0.1\% Tween-20 and 0.5\% milk powder. A chemiluminescence kit (Supersignal Nucleic Acid from Pierce, USA) was used for the detection of the DNA adducts. The detection limit of this method is 1 adduct per $10^{6}$ nucleotides.

\section{Results}

To determine the nitrosatability of DMA and MOR by NO-mediated nitrosation, these amines were incubated with $\mathrm{NO}^{\circ}$ at $\mathrm{pH} 7$ and $37^{\circ} \mathrm{C}$. Under these conditions (incubation of $500 \mu \mathrm{M}$ amine and $10 \mu \mathrm{M} \mathrm{NO}{ }^{\circ}$ ), about $0.004 \%$ and $0.01 \%$ of DMA and MOR, respectively, was nitrosated. Increasing the concentration of $\mathrm{NO}^{\circ}$ resulted in a linear increase of percentage nitrosated substrate.

Cell viability of the Caco-2 cells after incubation with activated PMN, and with DMA, MOR or MU, was determined by the MTT assay. The results are presented in Table 1. Incubation with activated PMN had no effect on cell viability. Also, methylurea was not cytotoxic to the Caco-2 cells; however, addition of dimethylamine or morpholine in the $1-5 \mathrm{mM}$ range, resulted in a decreased cell viability.

Nitrite production by activated PMN is shown in Figure 2. Activated PMN in the coincubations produced $1.9 \pm 0.3 \mu \mathrm{M}$ nitrite (mean $\pm \mathrm{SD}$ ). There was no difference in nitrite concentration after 1 or $3 \mathrm{~h}$ of incubation. After recalculation, $1.9 \mu \mathrm{M}$ of nitrite corresponds to $0.34 \mathrm{nmol} / 10^{6} \mathrm{PMN}$. Addition of DMA, MOR and MU had no effect on nitrite formation. 
Table 1. Cell viability of Caco-2 cells after incubation with activated PMN and DMA, MOR or MU.

\begin{tabular}{|c|c|c|}
\hline $\begin{array}{l}\text { Caco- } 2 \text { cells incubated } \\
\text { with: }\end{array}$ & $\begin{array}{l}\text { cell viability } \\
(\%)\end{array}$ & SD" \\
\hline PMN & 96 & 2.1 \\
\hline $\mathrm{PMN}+500 \mu \mathrm{M} \mathrm{DMA}$ & 90 & 1.4 \\
\hline $\mathrm{PMN}+1 \mathrm{mM}$ DMA & 89 & 1.4 \\
\hline PMN + 5 mM DMA & 74 & 3.5 \\
\hline $\mathrm{PMN}+500 \mu \mathrm{M} \mathrm{MOR}$ & 79 & 1.4 \\
\hline PMN + 1 mM MOR & 76 & 2.1 \\
\hline $\mathrm{PMN}+5 \mathrm{mM} \mathrm{MOR}$ & 66 & 0.7 \\
\hline$P M N+10 \mathrm{mM} M U$ & 95 & 2.1 \\
\hline $\mathrm{PMN}+100 \mathrm{mM} \mathrm{MU}$ & 93 & 0.0 \\
\hline $\mathrm{PMN}+200 \mathrm{mM} \mathrm{MU}$ & 98 & 1.4 \\
\hline
\end{tabular}

"SD: standard deviation

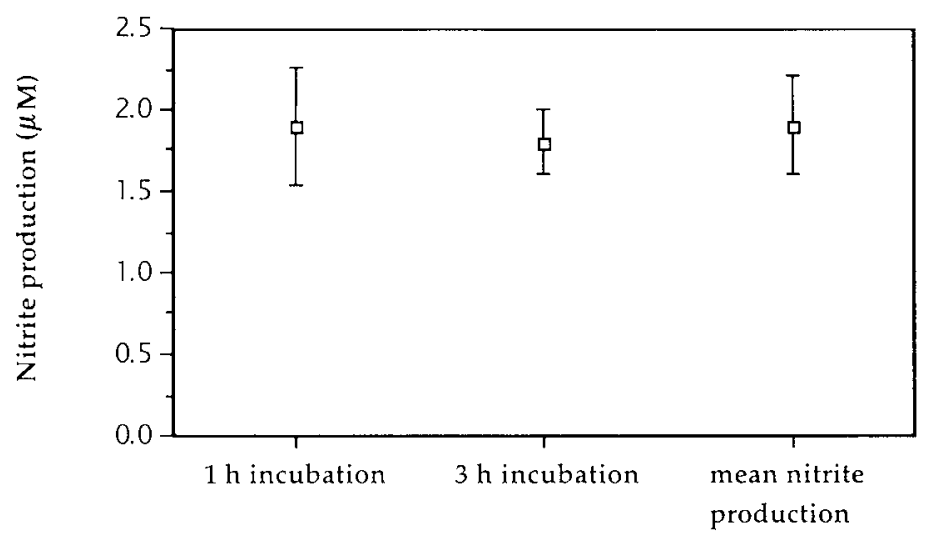

Figure 2: Nitrite production by activated PMN after 1 or $3 \mathrm{~h}$ of incubation. 
Table 2 and 3 summarize the results of the coincubations of Caco-2 cells with PMN and morpholine. Formation of NMOR increased with increasing concentrations of MOR. There was no significant difference in NMOR formation after 1 or $3 \mathrm{~h}$ of incubation. Coincubations with DMA were performed for $1 \mathrm{~h}$. No detectable amount of NDMA was formed.

Table 2. Formation of NMOR after 1 hour coincubations of Caco-2 cells and $P M N$ with MOR (mean $\pm S D ; n=6$ ).

\begin{tabular}{llll}
\hline [MOR] & $\begin{array}{l}\text { [NMOR] }(\mathrm{nM}) \\
\text { negative control }\end{array}$ & $\begin{array}{l}\text { [NMOR] }(\mathrm{nM}) \\
\text { coincubations }\end{array}$ & $\begin{array}{l}\text { NMOR formation } \\
\text { in coincubations }\end{array}$ \\
\hline $0 \mu \mathrm{M}^{2}$ & $\mathrm{ND}^{3}$ & $\mathrm{ND}$ & $\mathrm{ND}$ \\
$500 \mu \mathrm{M}$ & $0.3 \pm 0.4$ & $1.4 \pm 0.6$ & $1.1 \pm 0.2$ \\
$1 \mathrm{mM}$ & $1.2 \pm 1.7$ & $3.6 \pm 2.4$ & $2.4 \pm 1.1$ \\
$5 \mathrm{mM}$ & $2.6 \pm 1.0$ & $6.4 \pm 4.2$ & $3.5^{*} \pm 3.2$
\end{tabular}

[NMOR] in the coincubations minus the [NMOR] in the negative control

'Caco-2 cells in Eagle's MEM

"ND: non detectable

* Significantly increased formation of NMOR compared to negative control incubations with morpholine (Mann-Whitney, $\mathrm{p}=0.011$ )

Table 3. Formation of NMOR after 3 hour coincubations of Caco-2 cells and $\mathrm{PMN}$ with MOR (mean $\pm \mathrm{SD} ; \mathrm{n}=6$ ).

\begin{tabular}{llll}
\hline MOR] & $\begin{array}{l}\text { [NMOR] }(\mathrm{nM}) \\
\text { negative control }\end{array}$ & $\begin{array}{l}\text { [NMOR] }(\mathrm{nM}) \\
\text { coincubations }\end{array}$ & $\begin{array}{l}\text { NMOR formation } \\
\text { in coincubations }\end{array}$ \\
\hline $0 \mu \mathrm{M}^{2}$ & $\mathrm{ND}^{3}$ & $\mathrm{ND}$ & $\mathrm{ND}$ \\
$500 \mu \mathrm{M}$ & $1.3 \pm 0.9$ & $1.8 \pm 1.2$ & $0.3 \pm 0.4$ \\
$1 \mathrm{mM}$ & $1.6 \pm 1.1$ & $2.8 \pm 1.6$ & $1.2 \pm 0.9$ \\
$5 \mathrm{mM}$ & $3.4 \pm 1.6$ & $8.0 \pm 3.4$ & $4.2^{*} \pm 2.1$ \\
\hline
\end{tabular}

' $[N M O R]$ in the coincubations minus the [NMOR] in the negative control

${ }^{2} \mathrm{Caco}-2$ cells in Eagle's MEM

"ND: non detectable

* Significantly increased formation of NMOR compared to negative control incubations with morpholine (Mann-Whitney, $\mathrm{p}=0.017$ ) 
Addition of MNU to the coincubation of Caco-2 cells and PMN resulted in formation of N7-alkylguanosine adducts in DNA of the Caco-2 cells. The lowest concentration of MNU that formed a detectable amount of DNA adducts $(\approx 1$ adduct $/ 10^{6}$ nucleotides), was $10 \mu \mathrm{M}$. Higher concentrations of MNU showed an exponential increase in DNA adduct levels. Incubation of NDMA (ranging from 1 $\mu \mathrm{M}$ to $80 \mathrm{mM}$ ) with Caco-2 cells did not result in a detectable level of N7alkylguanosine adducts. Adduct formation by NMOR was not studied, since NMOR does not lead to alkylguanosine adducts, but to cyclic deoxyguanosine adducts.

MNU can not be analyzed by means of GC-MS. We tried to determine formation of MNU, after administration of MU, by spectrophotometric analysis (22). However, applying this method to quantitate formation of $\mathrm{MNU}$ at $\mathrm{pH} 7$ and at a temperature of $37^{\circ} \mathrm{C}$ appeared not possible, because of the instability of MNU at this $\mathrm{pH}$ and temperature. It was therefore tried to evaluate the formation of MNU in the coincubations with MU indirectly via detection of N7-alkylguanosine adducts. However, no alkyl-DNA adducts appeared to be formed after 1 or $3 \mathrm{~h}$ of incubation with MU in the range of $10-200 \mathrm{mM}$.

\section{Discussion}

In the present study, an in vitro model for intestinal inflammation was designed, to determine whether endogenous formation of carcinogenic NOC under conditions of for instance colitis, is feasible. Amines, derived from ingested food and from bacterial flora, are present in the colon leading, for example, to relatively high amounts of DMA in the colon lumen $(14,23)$. Inflammatory cells, such as PMN, may hypothetically produce sufficient amounts of nitrosating agents to result in formation of carcinogenic NOC. This may explain the association between chronic inflammation in the colon and an increased risk of colon cancer. The 1:10 ratio (Caco-2 : PMN) used in our coincubation experiments, reflects a severe inflammation as, for instance, occurring during colitis. Translating our results to a situation of severe inflammation in the colon, it should however be taken into account that the concentrations of amines used in the present study are higher than concentrations occurring in the human colon lumen, and appear to have some negative influence on cell viability.

Experiments with pure NO, DMA and MOR were performed to asses whether $\mathrm{NO}$, after conversion to $\mathrm{N}_{2} \mathrm{O}_{3}$ and $\mathrm{N}_{2} \mathrm{O}_{4}$, could nitrosate secondary amines at $\mathrm{pH} 7$, resulting in formation of carcinogenic nitrosamines. It appeared that nitrosatability of DMA and MOR, at $\mathrm{pH} 7$ and $37^{\circ} \mathrm{C}$, could indeed be demonstrated, and NDMA and NMOR appeared to be formed. 
The production of NMOR in the coincubation assay was however small. Furthermore, no detectable amount of NDMA was formed; within this respect, it has to be noted that MOR is more readily nitrosated than DMA. This implies that the NO production by PMN in the coincubation assay, at this rather high cell density, is quite low. In general, studies on the production of NO by human PMN show inconclusive results. Keller et al. (24) reported that human neutrophils did not produce nitrite (as index for NO generation) after incubation with different agents. According to Miles et al. (25), human PMN contain no iNOS activity, and this might explain why no detectable amounts of nitrite were formed in their experiments. In contrast, other studies do report generation of $\mathrm{NO}$ by human PMN, but the variation in detected NO levels between the different studies is high (26-28). Kausalya et al. (26) found low levels of nitrite, produced by cultured PMN (<60 pmol $/ 10^{6}$ cells). PMN stimulated by PMA for $30 \mathrm{~min}$, released $0.55 \mathrm{nmol}$ nitrite $/ 2 \times 10^{6}$ cells (28). Carreras et al. (27) directly measured NO production by PMN after addition of PMA and the maximal rate of $\mathrm{NO}$ production was 0.56 nmol $\mathrm{NO} \times \mathrm{min}^{-1} \times 10^{6}$ cells $^{-1}$. We have demonstrated a nitrite production of 0.34 $\mathrm{nmol} / 10^{6}$ cells, which is comparable with the level reported by Wright et al. (28).

Only one previous study has described nitrosamine formation by rat neutrophils, using inflammatory rat neutrophils and $0.2 \mathrm{mM} \mathrm{2,3-}$ diaminonaphthalene as nitrosatable substrate (7). Over a $4 \mathrm{~h}$ incubation period, $282 \mathrm{nM}$ of a nitrosamine derivative (1-naphtho(2,3)triazole) was produced by $2 \mathrm{x}$ $10^{6}$ cells. Comparing our data on human neutrophils with rat neutrophils (7), it can be suggested that at equivalent cell counts, rat neutrophils produce higher levels of nitrite (3.2 nmol $/ 10^{6}$ cells) and N-nitrosamines.

Also stimulated macrophages are capable of synthesizing nitrite, nitrate, and $\mathrm{N}$-nitrosamines after oxidation of $\mathrm{NO}$ to $\mathrm{N}_{2} \mathrm{O}_{3}$ and $\mathrm{N}_{2} \mathrm{O}_{4}(4-6)$. Comparing the production of nitrite by human PMN with the generation of nitrite by immortalized murine macrophages and peritoneal mouse macrophages (4-6), macrophages seem more effective in producing nitrite than PMN. As a consequence, during inflammation in the colon, macrophage-mediated $\mathrm{N}$ nitrosamine formation may quantitatively be more important than production of N-nitrosamines by neutrophils (4-6). For example, formation of NMOR by stimulated murine macrophages after incubation with $15 \mathrm{mM}$ MOR ranged from 114 to $940 \mathrm{nM}$ (4). However, for the ultimate comparison, this should be confirmed by experiments with human macrophages.

NDMA was not capable of inducing detectable levels of N7-alkylguanosine adducts in the Caco-2 cells. Apparently, Caco-2 cells lack sufficient cytochrome P$4502 \mathrm{E} 1$ activity to activate this N-nitrosamine (29). However, cultured nontumorous human colon, collected during surgery or autopsy, was found to metabolize NDMA and other N-nitrosamines (30). A very high interindividual variation was observed in the binding of NDMA to DNA (30). The authors 
discussed that part of this variation might be due to changes in cellular physiology of the cultured colon tissue. This reported metabolizing capacity of human colon suggests that even small amounts of NOC as formed by human neutrophils during intestinal inflammation, induce DNA modification in colon epithelial cells, and therefore may represent a risk factor for colon carcinogenesis.

No metabolic activity is necessary to activate MNU, since MNU spontaneously decomposes to form methyl adducts. MNU appeared directly capable of alkylating DNA of exposed Caco-2 cells. However, no N7alkylguanosine adducts were detected after the coincubations with $\mathrm{MU}$, indicating that $<10 \mu \mathrm{M}$ of $\mathrm{MNU}$ was formed. Compared with MOR, more MU will be nitrosated at equimolar concentrations (at optimum $\mathrm{pH}$ ) by its nitrosating agent $\mathrm{H}_{2} \mathrm{NO}_{2}{ }^{+}$. The concentrations of $\mathrm{MU}$ added to the coincubations should therefore be high enough to form $>10 \mu \mathrm{M}$ of MNU. However, the coincubations were obviously performed at $\mathrm{pH} 7$ and is has been reported that $\mathrm{N}_{2} \mathrm{O}_{3}$ and $\mathrm{N}_{2} \mathrm{O}_{4}$ which are present at this $\mathrm{pH}$ (Fig 1), are no suitable nitrosating agents for alkylureas $(29,31)$. Our results are therefore in agreement with these previous findings.

In conclusion, in this in vitro model simulating chronic colitis, human stimulated PMN are able to generate carcinogenic N-nitrosamines (but not alkylnitrosoureas), and this implies a risk factor for colon carcinogenesis. We could not demonstrate alkylation of target DNA in Caco-2 cells by the NOC, most probably because of the low metabolic rate of these cells. It remains possible that the NOC formed by human PMN result in DNA adduct formation in situ in view of the higher metabolic capacity of normal colon epithelium. However, levels of NOC probably will be low in situ, for instance as compared to intragastric formation of NOC (18). This suggests that formation of carcinogenic NOC by human PMN during inflammation in the colon, can not solely explain the observed association between chronic inflammation and colon cancer risk, given the low levels of nitrosation and of resulting DNA alkylation products.

\section{Acknowledgements}

The authors would like to thank G. Haenen, L. Baars and C. Heijnen for their help with the NO-experiments. 


\section{References}

1. Suzuki K, Mitsuoka T. N-nitrosamine formation by intestinal bacteria. In: ONeill I, Borstel RC von, Miller CT, Long J, Bartsch H. (ed.) N-Nitroso Compounds: Occurrence, Biological Effects and Relevance to Human Cancer. IARC Sci. Publ., International Agency for Research on Cancer, Lyon, No 57, pp. 275-281 (1984).

2. Calmels S, Ohshima H, Bartsch H. Nitrosamine formation by denitrifying and nondenitrifying bacteria: implication of nitrite reductase and nitrate reductase in nitrosation catalysis. J Gen Microbiol 134: 221-226 (1988).

3. Ohshima $\mathrm{H}$, Bartsch $\mathrm{H}$. Chronic infections and inflammatory processes as cancer risk factors: possible role of nitric oxide in carcinogenesis. Mutat Res 305: 253-264 (1994).

4. Miwa M, Stuehr DJ, Marletta MA, Wishnok JS, Tannenbaum SR. Nitrosation of amines by stimulated macrophages. Carcinogenesis 8: 955-958 (1987).

5. Iyengar R, Stuehr DJ, Marletta MA. Macrophage synthesis of nitrite, nitrate, and Nnitrosamines: precursors and role of the respiratory burst. Proc Natl Acad Sci 84: 6369-6373 (1987).

6. Kosaka H, Wishnok JS, Miwa M, Leaf CD, Tannenbaum SR. Nitrosation by stimulated macrophages. Inhibitors, enhancers and substrates. Carcinogenesis 10: 563566 (1989).

7. Grisham MB, Ware K, Gilleland HE Jr., Gilleland LB, Abell CL, Yamada T. Neutrophil-mediated nitrosamine formation: role of nitric oxide in rats. Gastroenterology 103: 1260-1266 (1992).

8. Gaston B, Drazen JM, Loscalzo J, Stamler JS. The biology of nitrogen oxides in the airways. Am J Respir Crit Care Med 149: 538-551 (1994).

9. Weitzman SA, Gordon LI. Inflammation and cancer: role of phagocyte-generated oxidants in carcinogenesis. Blood 76: 655-663 (1990).

10. Collins RH, Feldman M, Fordtran JS. Colon cancer, dysplasia and surveillance in patients with ulcerative colitis: a critical review. N Engl J Med 316: 1654-1658 (1987).

11. Ekbom A, Helmick C, Zach M, Adami HO. Ulcerative colitis and colorectal cancer: a population-based study. N Engl J Med 323: 1228-1233 (1990).

12. Gilat T, Fireman Z, Grossman A, Hacohen D, Kadish U, Ron E, Rozen P, Lilos P. Colorectal cancer in patients with ulcerative colitis. A population study in central Israel. Gastroenterology 94: 870-877 (1988).

13. Lennard-Jones JE, Melville DM, Morson BC, Ritchie JK, Williams CB. Precancer and cancer in extensive ulcerative colitis: findings among 401 patients over 22 years. Gut 31: 800-806 (1990).

14. Roediger WEW, Lawson MJ, Radcliffe BC. Nitrite from inflammatory cells-A cancer risk factor in ulcerative colitis? Dis Colon Rectum 33: 1034-1036 (1990).

15. Weast RC, Astle MJ, Beyer WH (ed.). CRC handbook of chomistry and physics. $66^{\text {"h }}$ editon. CRC Press Inc, Boca Raton, Florida (1985).

16. Knaapen AM, Seiler F, Schilderman PAEL, Nehls P, Bruch J, Schins RPF, Borm PJA. Neutrophils cause oxidative DNA damage in alveolar epithelial cells. Free Radic Biol Med 27: 234-240 (1999).

17. Mosmann T. Rapid colometric assay for cellular growth and survival: application to proliferation and cytotoxicity assays. J Immmol Meth 65: 516-527 (1983). 
18. Vermeer ITM, Pachen DMFA, Dallinga JW, Kleinjans JCS, Van Maanen JMS. Volatile $\mathrm{N}$-nitrosamine formation after intake of nitrate at the ADI level in combination with an amine-rich diet. Environ Health Perspect 106: 459-463 (1998).

19. Gupta RC. Nonrandom binding of the carcinogen N-hydroxy-2-acetyl-aminofluorene to repetitive sequences of rat liver DNA in vivo. Proc Nat Acad Sci 81: 6934-6947 (1984).

20. Delft JHM van, Winden MJM van, Luiten-Schuite A, Ribeiro LR, Baan RA. Comparison of various immunochemical assays for the detection of ethylene oxide-DNA adducts with monoclonal antibodies against imidazole ring-opened N7-(2-hydroxyethyl)guanosine: application in biological monitoring study. Carcinogeresis 15: 1867-1873 (1994).

21. Delft JHM van, Weert EJM van, Schellekens MM, Claassen E, Baan RA. The isolation of monoclonal antibodies selected for the detection of imidazole ring-opened N7ethylguanine in purified DNA and in cells in situ. Crossreaction with methyl, 2hydroxyethyl and sulphur mustard adducts. Carcinogenesis 12: 1041-1049 (1991).

22. Badaev SA, Gichner T, Pospísil F, Veleminsky J. Human acids inhibit the formation. but not the mutagenicity of N-methyl-N-nitrosourea. Mutat Res 210: 9-13 (1989).

23. Macfarlane GT, Cummings JH. The colonic flora, fermentation, and large bowel digestive function. In: Phillips SF, Pemberton JH, Shorter RG (ed.) The large intestine: physiology, pathophysiology, and disease. Raven Press, New York (1991).

24. Keller R, Keist R, Erb P, Aebischer T, De Libero G, Balzer M, Groscurth P, Keller HU. Expression of cellular effector functions and production of reactive nitrogen intermediates: a comparative study including T lymphocytes, T-like cells, neutrophil granulocytes, and mononuclear phagocytes. Cell Immunol 131: 398-403 (1990).

25. Miles AM, Owens MW, Milligan S, Johnson GG, Fields JZ, Ing TS, Kottapalli V, Keshavarzian A, Grisham MB. Nitric oxide synthase in circulating vs. extravasated polymorphonuclear leukocytes. J Leukoc Biol 58: 616-622 (1995).

26. Kausalya $S$, Nath $J$. Interactive role of nitric oxide and superoxide anion in neutrophil-mediated endothelial cell injury. J Leukoc Biol 64: 185-191 (1998).

27. Carreras MC, Pargament GA, Catz SD, Poderoso JJ, Boveris A. Kinetics of nitric oxide and hydrogen peroxide production and formation of peroxynitrite during the respiratory burst of human neutrophils. FEBS Lett 341: 65-68 (1994).

28. Wright CD, Mülsch A, Busse R, Osswald H. Generation of nitric oxide by human neutrophils. Biochem Biophys Res Commun 160: 813-819 (1989).

29. Mirvish SS. Role of N-nitroso compounds (NOC) and N-nitrosation in etiology of gastric, esophageal, nasopharyngeal and bladder cancer and contribution to cancer of known exposures to NOC. Cancer Lett 93: 17-48 (1995).

30. Autrup H, Harris CC, Trump BF. Metabolism of acyclic and cyclic N-nitrosamines by cultured human colon. Proc Soc Exp Biol Med 159: 111-115 (1978).

31. Mirvish SS. Formation of N-nitroso compounds: chemistry, kinetics, and in vivo occurrence. Toxicol Appl Pharmacol 31: 325-351 (1975). 
Chapter 8

General discussion and summary 
Humans are all undoubtedly exposed to endogenously formed $N$-nitroso compounds and, to a more or lesser extent, to exogenous NOC. Studies with experimental animals have shown that NOC are carcinogenic in a wide variety of animal species, and that some NOC are extremely potent carcinogens $(1,2)$. There are strong indications that NOC can be carcinogenic also in humans. GC-TEA is a method widely applied to determine the levels of NOC in body fluids. In our laboratory, a GC-MS method was developed to determine the levels of nitrosamines in urine and gastric juice samples. In Chapter 2, both methods were compared by detection of NDMA levels in artificial gastric juice samples. There was a strong correlation between the two assays, demonstrating the applicability of both methods for determination of nitrosamines.

Nitrate, ingested via food and drinking water, is an important precursor of nitrosating agents, after conversion to nitrite in the oral cavity, that can react with amines and amides in the stomach to form $\mathrm{N}$-nitroso compounds. As for many compounds, safety guidelines have been set for nitrate and nitrite to protect humans against possible adverse effects related to intake of these ions. However, the subsequent endogenous formation of NOC was not taken into account in setting standards for nitrate and nitrite.

Therefore, the study described in Chapter 3 was performed to generate data on endogenous NOC synthesis after nitrate intake at the ADI level in combination with fish as a source rich in nitrosatable precursors. The results show a significantly increased NDMA excretion in urine, implying the risk of increased formation of carcinogenic N-nitrosamines after nitrate intake at the ADI level. Several epidemiologic studies reported no or even an inverse relationship between nitrate intake and human cancer $(3,4)$. It has been suggested that this is due to the presence of vitamin $\mathrm{C}$ and other antioxidants in nitrate-containing vegetables. The molar antioxidant/nitrate ratio might be the determining factor, since an excess of nitrosation inhibitors would result in a protective effect of a nitrate-rich vegetable against formation of NOC (5). However, the study described in Chapter 3 clearly showed that nitrosamine formation increased during nitrate intake in combination with a fish meal, in spite of concomitant consumption of vegetables. Nitrate intake at the level of the ADI combined with fish consumption resulted in an increase in urinary NDMA excretion of about $200 \%$. In this study, the volunteers received a nitrate load in drinking water instead of nitrate-rich vegetables. In a previous study in our laboratory, a significant increase of $240 \%$ in NDMA excretion in urine was also observed after consumption of a diet containing nitrate-rich vegetables, with a mean nitrate content of the meals of $274 \mathrm{mg}$ (6). This demonstrates that the amount of inhibitors of nitrosation present in the diet is not sufficient to prevent endogenous formation of NOC after nitrate intake at the level of the ADI. 
In Chapter 4, the possible inhibition of endogenous formation of nitrosamines by ascorbic acid supplementation and green tea consumption was studied. The effect of two different doses of ascorbic acid (250 $\mathrm{mg}$ and $1 \mathrm{~g}$ ) and two different doses of green tea ( $2 \mathrm{~g}$ and $4 \mathrm{~g}$ ) on nitrosation was investigated during four test weeks, and every test week was alternated with a control week (low nitrate intake). Urine samples were pooled from days 1-3 and from days 4-7. During days $1-3$ in the four test weeks, no effect of supplementation with ascorbic acid and consumption of green tea was observed. In contrast, studies using the NPRO test reported inhibitory effects of ascorbic acid supplementation and green tea consumption within $24 \mathrm{~h}$ after intake (7-11). The absence of an inhibiting effect of ascorbic acid and green tea on NDMA formation during days 1-3 in our study cannot be explained. However, during days 4-7, $250 \mathrm{mg}$ and $1 \mathrm{~g}$ of ascorbic acid and $2 \mathrm{~g}$ (4 cups) of green tea significantly decreased NDMA excretion in urine, to a level comparable with the control weeks. Supplementation with $250 \mathrm{mg}$ of ascorbic acid was sufficient to decrease NDMA excretion to a maximum extent, and increasing the dose to $1 \mathrm{~g}$ had no additional effect. Even after intake of nitrosation inhibitors, there was still a baseline level of NDMA detectable in urine. This NDMA is probably partly derived from the diet, partly from nitrosation of dimethylamine by other nitrosating agents, and partly from nitrosation at sites of the body that were not accessible for the inhibitors. This phenomenon was also observed in studies using the NPRO test $(9,12,13)$. Consumption of $4 \mathrm{~g}$ (8 cups) of green tea significantly increased urinary excretion of NDMA during days $4-7$. Tea contains phenolic compounds, which can act as powerful nitrosating agents after formation of C-nitroso derivates, and this may be the explanation for the catalytic effect of high amounts of green tea on nitrosation (14-16).

To assess the health risk associated with the levels of nitrosamine excretion as described in Chapter 3 and 4 after a high nitrate intake by healthy volunteers, nitrosamine excretion was studied in a group possibly at high risk of endogenous NOC formation: patients with a high $\mathrm{pH}$ in the stomach, who were recruited among patients receiving long-term treatment with the proton pump inhibitor omeprazole (Chapter 5). Gastric juice and gastric biopsies were also sampled, which created the opportunity to study nitrosamine levels in gastric juice, and DNA damage in one of the target tissues of NOC. These data would be valuable for the risk-evaluation of both the healthy volunteers, and the group of patients at high risk of endogenous NOC formation. However, the patient group that was studied, appeared not to be at high risk of increased endogenous formation of NOC. There was no difference in intragastric nitrosamine levels between the patient group and the healthy control subjects. Duration of omeprazole therapy was not related to the level of intragastric nitrosamines or urinary excretion of nitrosamines. The patient group did show a significantly higher nitrosamine excretion in urine compared with the control subjects, implying the risk of 
increased nitrosamine formation, possibly at other sites than the stomach. In the Appendix of Chapter 5, the urinary NDMA excretion in the patient group was compared with the NDMA excretion in the healthy volunteers during days 1-3 and days 4-7 after nitrate intake at ADI level in combination with fish. The data suggest that endogenous formation of nitrosamines in the patient group was lower than in healthy volunteers after nitrate intake at the ADI level. An important difference is that in Chapter 3 urine samples were collected for $24 \mathrm{~h}$ and from the patient group early morning urine samples were obtained. Thus, this comparison has to be interpreted with caution. DNA adducts were not observed in DNA from the gastric biopsies; however, the relatively high detection limit of the assay to determine alkylguanosine adducts has to be taken into consideration. The long-term study described in Chapter 5 did confirm the outcome of several short-term studies (17-19) about the safety of treatment with proton pump inhibitors, concerning the formation of carcinogenic NOC.

The stomach is considered to be the most important site for endogenous formation of NOC, since the nitrosation reaction is catalyzed in an acidic environment. At neutral pH, bacteria are able to catalyze formation of NOC (20). Helicobacter pylori is a bacterium with a high incidence of gastric colonization. $H$. pylori infection is a risk factor for chronic gastritis and intestinal metaplasia, which represent an increased risk for gastric cancer. $H$. pylori is a special bacterium, since it is the only bacterium known with the capacity to colonize the acidic stomach. It was previously shown that $H$. pylori has a low nitrosation capacity (21). However, $H$. pylori is a highly diverse species, and these experiments were performed with only one strain, and with a non-carcinogenic N-nitroso compound as end product. The study presented in Chapter 6 was performed to further elucidate the contribution of $H$. pylori to endogenous nitrosation. The results show that both in a neutral and in an acidic environment no significant formation of nitrosomorpholine was induced by any of the H. pylori strains. Neisseria cinerea served as a positive control, and this bacterium significantly catalyzed the nitrosation reaction, indicating that the test conditions were suitable for studying bacterially catalyzed nitrosamine formation. These results indicate that $H$. pylori infection is not a contributing factor to intragastic formation of carcinogenic nitrosamines.

In Chapter 7, extragastric formation of N-nitroso compounds was studied, using an in vitro model for chronic inflammation in the human colon: a coincubation system with human colon cells (Caco-2 cells) and activated human polymorphonuclear leukocytes (PMN). This model was used to study the role of activated PMN in formation of carcinogenic NOC mediated through production of NO, and to investigate whether the synthesized NOC could induce alkyl-DNA adducts in Caco- 2 cells. Dimethylamine, morpholine and methylurea were added to the coincubations as nitrosatable precursors. Addition of $5 \mathrm{mM}$ morpholine 
resulted in a small, but significant increase in NMOR formation. Addition of dimethylamine and methylurea did not result in detectable amounts of NDMA and MNU. Furthermore, no detectable amounts of alkylated DNA could be observed in the Caco-2 cells. These results suggest that human PMN are able to synthesize low levels of carcinogenic NOC in the colon during inflammation, but also that those NOC do not damage DNA in colon epithelial target cells, possibly due to detoxification in the cytosol before the DNA was reached. In the in situ situation, the levels of NOC synthesized by activated PMN will be low, and other factors are probably also contributing to the association between chronic inflammation and colon cancer risk.

In conclusion, the data presented in this thesis show that nitrate intake at the ADI level in combination with fish consumption resulted in an increase in NDMA excretion in urine of about $200 \%$, reflecting an increased endogenous formation of NDMA. However, based on these results, only a very rough estimation can be made about the levels of NDMA formed in the stomach. Supplementation with ascorbic acid, and consumption of moderate doses of green tea caused complete inhibition of the increase in NDMA excretion, indicating that chemoprevention of endogenous formation of carcinogenic NOC is achievable. These studies were performed with healthy volunteers. Interestingly, in patients at increased risk for intragastric NOC formation, urinary NOC excretion appears lower than in nitrate supplemented volunteers. The in vitro data in Chapter 6 furthermore indicate that patients with a Helicobacter pylori infection are not at increased risk for endogenous formation of nitrosamines in the stomach.

The second aim of this thesis was to evaluate possible DNA damaging effects of endogenously formed carcinogenic NOC. Although in general NOC levels in the stomach will be relatively high compared with other sites of the body, no N7-alkylguanosine adducts and K-ras mutations were detected in DNA isolated from gastric biopsies of patients with a high intragastric $\mathrm{pH}$. Unfortunately, the detection limit of the assay for alkyl-DNA adducts was relatively high ( 1 adduct $/ 10^{6}$ nucleotides), and genotoxic consequences of NOC exposure cannot be excluded based on these data. However, reported levels of N7-methylguanine in lymphocytes from healthy non-smoking individuals were $13.5 / 10^{7}$ nucleotides (22). It can be suggested that DNA adduct levels in a target organ like the stomach are expected to be higher than in lymphocytes, if there would be a quantitatively important effect of NOC exposure on DNA, and consequently, the detection limit of our assay would be acceptable.

Concerning endogenous nitrosation at other sites in the body besides the stomach, the in vitro study with the coincubation system suggests that endogenous formation of carcinogenic nitrosamines can also occur in the 
intestinal tract, mediated by activated inflammatory cells, and most probably, at low to moderate levels, again not leading to DNA adduct formation.

Overall, although the studies presented in this thesis provide a lot of information on endogenous formation of carcinogenic nitrosamines, no final conclusion can be drawn regarding the relation between high nitrate exposure and a possible cancer risk for humans. Nevertheless, the study with nitrate intake at the ADI level did demonstrate that endogenous formation of NOC has to be taken into account in setting standards for nitrate and nitrite. This does not necessarily implicate a change in the absolute level of the standards, since this was a worst-case approach, but it does indicate that particularly the risk groups defined in Chapter 1 should be careful with frequent consumption of nitrate-rich vegetables in combination with fish.

It is important for future research to develop more sensitive assays for detection of alkyl-DNA adducts, in order to gain more insight in the genotoxic consequences of endogenous NOC formation. Furthermore, more data are needed on endogenous formation of NOC in the stomach, and the gastro-intestinal tract model described in Chapter 2 can play an important role in reaching this goal.

\section{References}

1. Bogovski P, Bogovski S. Animal species in which $\mathrm{N}$-nitroso compounds induce cancer. Int J Cancer 27: 471-474 (1981).

2. Peto R, Gray R, Brantom P, Grasso P. Nitrosamine carcinogenesis in 5120 rodents: chronic administration of sixteen different concentrations of NDEA, NDMA, NPYR and NPIP in the water of 4440 inbred rats, with parallel studies on NDEA alone of the effect of age of starting (3,6 or 20 weeks) and of species (rats, mice or hamsters). In: N-Nitroso Compounds: Occurrence, Biological Effects and Relevance to Human Cancer (ONeill I, Borstel RC von, Miller CT, Long J, Bartsch H). IARC Sci Publ No 57. Lyon: International Agency for Research on Cancer, pp. 627-665 (1984).

3. Boeing $\mathrm{H}$. Epidemiological research in stomach cancer: progress over the last ten years. J Cancer Res Clin Oncol 117: 133-143 (1991).

4. Forman D. Dietary exposure to N-nitroso compounds and the risk of human cancer. Cancer Surv 6: 719-738 (1987).

5. Bartsch H, Ohshima H, Pignatelli B. Inhibitors of endogenous nitrosation. Mechanisms and implications in human cancer prevention. Mutat Re's 202: 307-324 (1988).

6. Maanen JMS van, Pachen DMFA, Dallinga JW, Kleinjans JCS. Formation of nitrosamines during consumption of nitrate- and amine-rich food and the influence of the use of mouthwashes. Cancer Detect Prev 22: 204-212 (1998).

7. Mirvish SS. Experimental evidence for inhibition of $\mathrm{N}$-nitroso compound formation as a factor in the negative correlation between vitamin $C$ consumption and the incidence of certain cancers. Cancer Res 54: 1948S-1951S (1994). 
8. Helser MA, Hotchkiss HJ, Roe DA. Temporal influence of ascorbic acid dose on the endogenous formation of $\mathrm{N}$-nitrosoproline and $\mathrm{N}$-nitrosothiazolidine-4-carboxylic acid in humans. J Nutr Biochem 2: 268-273 (1991).

9. Wu YN, Wang $\mathrm{HZ}$, Li LS, Han C. The inhibitory effect of Chinese tea and its polyphenols on in vitro and in vivo N-nitrosation. Biomed Environ Sci 6: 237-258 (1993).

10. Stich HF. Teas and tea components as inhibitors of carcinogen formation in model systems and man. Prev Med 21: 377-384 (1992).

11. $X_{u}$ GP, Song PJ, Reed PI. Effects of fruit juices, processed vegetable juice, orange peel and green tea on endogenous formation of $\mathrm{N}$-nitrosoproline in subjects from a high-risk area for gastric cancer in Moping County, China. Eur J Cancer Prev 2: 327335 (1993).

12. Garland WA, Kuenzig W, Rubio F, Kornychuk H, Norkus EP, Conney AH. Urinary excretion of nitrosodimethylamine and nitrosoproline in humans: interindividual and intraindividual differences and the effect of administered ascorbic acid and alpha-tocopherol. Cancer Res 46: 5392-5400 (1986).

13. Wagner DA, Shuker DEG, Bilmazes C, Obiedzinski M, Baker I, Young VR, Tannenbaum SR. Effects of vitamins $C$ and $E$ on endogenous synthesis of $N$ nitrosamino acids in humans: precursor-product studies with $\left[{ }^{15} \mathrm{~N}\right]$ nitrate. Cancer Res 45: 6519-6522 (1985).

14. Nakamura M, Kawabata T. Effect of Japanese green tea on nitrosamine formation in vitro. J Food Sci 46: 306-307 (1981).

15. Pignatelli B, Bereziat, J-C, Descotes G, Bartsch H. Catalysis of nitrosation in vitro and in vivo in rats by catechin and resorcinol and inhibition by chlorogenic acid. Carcinogenesis 3: 1045-1049 (1982).

16. Davies R, Dennis MJ, Massey RC, McWeeny DJ. Some effects of phenol- and thiolnitrosation reactions on N-nitrosamine formation, in: Walker EA, Griciute L, Castegnaro M, Lyle RE (Eds). Environmental aspects of $N$-nitroso compounds. IARC Scientific Publications No. 19, International Agency for Research on Cancer, Lyon, pp. 183-197 (1978).

17. Verdu E, Viani F, Armstrong D, Fraser R, Siegrist HH, Pignatelli B, Idstrom JP, Cederberg C, Blum AL, Fried M. Effect of omeprazole on intragastric bacterial counts, nitrates, nitrites, and N-nitroso compounds. Gut 35: 455-460 (1994).

18. Thorens J, Froehlich F, Schwizer W, Saraga E, Bille J, Gyr K, Duroux P, Nicolet M, Pignatelli B, Blum AL, Gonvers JJ, Fried M. Bacterial overgrowth during treatment with omeprazole compared with cimetidine: a prospective randomised double blind study. Gut 39: 54-59 (1996).

19. Houben GMP, Hooi J, Brummer R-JM, Stobberingh EE, Stockbrugger RW. Intragastric bacterial growth, nitrates, nitrites and $N$-nitroso compounds after 300 mg ranitidine b.d., $20 \mathrm{mg}$ omeprazole, $40 \mathrm{mg}$ omeprazole and placebo. Eur I Cancer Prev 5 (suppl 1): 59-61 (1996).

20. Leach SA, Thompson M, Hill M. Bacterially catalysed N-nitrosation reactions and their relative importance in the human stomach. Carcinogenesis 8: 1907-1912 (1987).

21. Ziebarth D, Spiegelhalder B, Bartsch H. N-nitrosation of medicinal drugs catalysed by bacteria from human saliva and gastro-intestinal tract, including Helicobacter pylori. Carcinogenesis 18: 383-389 (1997). 
22. Mustonen R, Hemminki K. 7-Methylguanine levels in DNA of smokers' and nonsmokers' total white blood cells, granulocytes and lymphocytes. Carcinogenesis 13: 1951-1955 (1992). 


\section{Samenvatting}

Ongetwijfeld worden alle mensen blootgesteld aan $\mathrm{N}$-nitroso verbindingen (NOC) die in het lichaam worden gevormd. Bovendien worden mensen in meer of mindere mate blootgesteld aan NOC van exogene oorsprong. Proefdierstudies hebben aangetoond dat NOC kankerverwekkend zijn in veel diersoorten en dat enkele NOC een uitermate hoge kankerverwekkende activiteit bezitten. Er zijn sterke aanwijzingen dat NOC ook kankerverwekkend zijn in mensen. Een veel gebruikte methode om NOC aan te tonen in lichaamsvloeistoffen is GC-TEA (gas chromatografie-thermische energie analyse). In ons laboratorium is een techniek ontwikkeld om nitrosamines in urine- en maagsapmonsters aan te tonen door middel van GC-MS (gas chromatografie-massa spectrometrie). In Hoofdstuk 2 zijn beide methoden onderling vergeleken door $\mathrm{N}$-nitrosodimethylamine (NDMA) niveaus te meten in monsters van artificieel maagsap. Er bleek een sterke correlatie te bestaan tussen de twee methoden, waaruit geconcludeerd kan worden dat beide methoden geschikt zijn om nitrosamines te bepalen.

Mensen nemen nitraat op via voeding en drinkwater, en na opname in de darn en recirculatie, wordt een gedeelte van het nitraat in de mondholte omgezet in nitriet. Vervolgens kan nitriet in de maag reageren met amines en amides, resulterend in de vorming van $\mathrm{N}$-nitroso verbindingen. Om mensen te beschermen tegen gezondheidsrisico's die het gevolg kunnen zijn van inname van nitraat en nitriet, zijn er voor deze stoffen veiligheidsnormen vastgesteld, zoals overigens voor vele stoffen is gedaan. Echter, bij het vaststellen van de aanvaardbare dagelijkse inname (ADI) voor nitraat en nitriet is geen rekening gehouden met de vorming van potentieel kankerverwekkende NOC in het lichaam.

Om gegevens te verkrijgen over de endogene vorming van NOC na inname van nitraat ter hoogte van de ADI, in combinatie met vis die immers rijk is aan nitroseerbare verbindingen zoals amines, is de studie uitgevoerd die beschreven is in Hoofdstuk 3. De resultaten laten een significante verhoging zien van de uitscheiding van NDMA in urine, wat impliceert dat er een risico bestaat op verhoogde vorming van kankerverwekkende nitrosamines na inname van nitraat ter hoogte van de huidige norm. Uit enkele epidemiologische studies is echter gebleken dat er geen relatie bestaat tussen nitraat inname en kanker, of zelfs dat nitraat inname beschermend werkt tegen het ontstaan van kanker. Er is gesuggereerd dat dit veroorzaakt zou worden door de aanwezigheid van vitamine $C$ en andere antioxidanten in groenten die nitraat bevatten. De molaire 
verhouding tussen antioxidant en nitraat zou hierbij de bepalende factor kumnen zijn, aangezien inname van een overmaat van remmers van nitrosering zou resulteren in een beschermend effect van een nitraatrijke groente tegen de vorming van NOC. De studie die beschreven is in hoofdstuk 3 toont echter aan dat nitrosaminevorming verhoogd is tijdens nitraat inname in combinatie met een vismaaltijd, ondanks de gelijktijdige consumptie van groenten. Nitraat inname ter hoogte van de ADI, gecombineerd met vis, resulteerde in een verhoging van de urinaire uitscheiding van NDMA van ongeveer 200\%. In deze studie consumeerden de vrijwilligers geen nitraatrijke groenten, maar nitraat opgelost in drinkwater. In een voorgaande studie die in ons laboratorium is uitgevoerd, hebben vrijwilligers wel een maaltijd met nitraatrijke groenten geconsumeerd, waarbij het gemiddelde nitraatgehalte van de maaltijden $274 \mathrm{mg}$ was. Dit resulteerde in een significante verhoging van de NDMA uitscheiding in urine van $240 \%$. Hiermee wordt aangetoond dat het gehalte aan remmers van nitrosering in de voeding niet voldoende is om endogene vorming van NOC te voorkómen na inname van nitraat ter hoogte van de ADI.

In Hoofdstuk 4 is de mogelijke remming van endogene nitrosaminevorming bestudeerd door supplementatie met vitamine $\mathrm{C}$ en door consumptie van groene thee. Het effect van twee verschillende doseringen vitamine C $(250 \mathrm{mg}$ en $1 \mathrm{gr}$ ) en twee verschillende doseringen groene thee ( 2 en $4 \mathrm{gr}$ ) op endogene nitrosering is bestudeerd tijdens 4 testweken, waarbij iedere testweek werd afgewisseld met een controleweek (lage nitraat inname). De urinemonsters van de dagen 1-3 en van de dagen 4-7 werden gepoold. Tijdens de dagen 1-3 had supplementatie met vitamine $C$ en consumptie van groene thee geen effect op de vorming van nitrosamines. Echter, een aantal studies die gebruik hebben gemaakt van de NPRO-test (nitrosoproline), hebben wel een remmend effect gerapporteerd van vitamine $C$ supplementatie en groene thee consumptie, binnen 24 uur na inname. Er is geen verklaring voor de afwezigheid van een remmend effect in onze studie van vitamine $C$ en groene thee op de vorming van NDMA tijdens de dagen 1-3. Tijdens de dagen 4-7 werd de uitscheiding van NDMA in urine significant verlaagd na inname van $250 \mathrm{mg}$ en $1 \mathrm{gr}$ vitamine $\mathrm{C}$ en $2 \mathrm{gr}$ (4 koppen) groene thee, tot een niveau dat vergelijkbaar is met de controleweken. Supplementatie met $250 \mathrm{mg}$ vitamine $\mathrm{C}$ was voldoende om de maximale verlaging van NDMA uitscheiding te bewerkstelligen, en een verhoging van de supplementatie tot $1 \mathrm{gr}$ had geen extra remmend effect. Echter, zelfs na de inname van remmers van nitrosering was er toch nog een detecteerbaar basisniveau van NDMA aanwezig in urine. Dit NDMA is waarschijnlijk voor een deel afkomstig van de voeding, voor een deel afkomstig van nitrosering van dimethylamine door andere nitroserende stoffen en voor een deel van nitrosering die heeft plaatsgevonden in delen van het lichaam die niet toegankelijk waren voor de remmers. Dit fenomeen is ook aangetoond in studies die de NPRO test hebben 
gebruikt. Voorts toonde onze studie aan dat consumptie van 4 gr (8 koppen) groene thee tot een significante verhoging van de uitscheiding van NDMA in urine leidt tijdens de dagen 4-7. Thee bevat fenolische stoffen die na de vorming van C-nitroso derivaten als sterke oxiderende agentia kunnen optreden, en dit zou een verklaring kunnen zijn voor het katalytische effect van consumptie van 8 koppen groene thee op endogene nitrosering.

De volgende doelstelling was om het gezondheidsrisico te schatten dat geassocieerd is met de niveaus van nitrosamine uitscheiding na een hoge nitraat inname door gezonde vrijwilligers zoals beschreven is in Hoofdstuk 3 en 4 . Daarom is nitrosamine uitscheiding tevens bestudeerd in een groep die mogelijk hoog risico loopt voor endogene vorming van NOC: patiënten met een hoge pH in de maag, zoals onder andere het geval is bij patiënten die langdurig behandeld worden met de protonenpomp-remmer omeprazole (Hoofdstuk 5). Er zijn ook monsters genomen van maagsap en maagbiopten, hetgeen de mogelijkheid creëerde om nitrosamine niveaus in maagsap en DNA schade in één van de doelwitweefsels van NOC te bestuderen. Deze data zouden waardevol zijn voor de risico-evaluatie van zowel de gezonde vrijwilligers als de groep van patiënten met een hoog risico op endogene NOC vorming. Echter, de patiëntengroep die bestudeerd is, bleek geen hoog risico te hebben op verhoogde endogene vorming van NOC. Er was geen verschil in nitrosamine niveaus in de maag tussen de patiëntengroep en de gezonde controlepersonen. De duur van behandeling met omeprazole was niet gerelateerd aan het niveau van nitrosamines in de maag of uitscheiding van nitrosamines in urine. De patiëntengroep had wel een significant hogere nitrosamine uitscheiding in urine vergeleken met de controlepersonen, en dit impliceert het risico van verhoogde nitrosamine vorming, mogelijk op andere plaatsen dan de maag. In de Appendix van Hoofdstuk 5 is de urinaire NDMA uitscheiding in de patiëntengroep vergeleken met de NDMA uitscheiding in de gezonde vrijwilligers tijdens de dagen 1-3 en 4-7 na nitraat inname ter hoogte van de ADI in combinatie met vis. De data suggereren dat endogene vorming van nitrosamines in de patiëntengroep lager was dan in gezonde vrijwilligers na inname van nitraat ter hoogte van de ADI. Een belangrijk verschil is dat de urinemonsters in Hoofdstuk 3 gedurende 24 uur verzameld werden terwijl van de patiëntengroep monsters van de ochtend-urine verkregen waren. Dus deze vergelijking moet voorzichtig worden geïnterpreteerd. In de maagbiopten werden geen DNA adducten gedetecteerd; hierbij moet wel de relatief hoge detectielimiet van de methode om alkylguanosine adducten te bepalen, in ogenschouw worden genomen. De lange-termijn studie die is beschreven in Hoofdstuk 5, bevestigt de uitkomst van enkele eerder verschenen korte-termijn studies over de veiligheid van behandeling met protonenpomp remmers, wat betreft de vorming van kankerverwekkende NOC. 
De maag wordt beschouwd als de belangrijkste plaats voor endogene vorming van NOC, aangezien de nitroseringsreactie wordt gekatalyseerd in een zuur milieu. Bij neutrale pH zijn bacteriën in staat om de vorming van NOC te katalyseren. Helicobacter pylori is een bacterie die met een hoge incidentie voorkomt in de maag. H. pylori infectie is een risicofactor voor chronische gastritis en intestinale metaplasie en deze aandoeningen representeren een verhoogd risico op maagkanker. H. pylori is een speciale bacterie, aangezien het de enige bacterie is waarvan bekend is dat hij de zure maag kan koloniseren. Voorheen is aangetoond dat $H$. pylori een relatief lage nitroseringscapaciteit heeft. Deze experimenten waren uitgevoerd met slechts één stam en met een nietkankerverwekkende N-nitroso verbinding als eindproduct. De studie die beschreven is in Hoofdstuk 6 is uitgevoerd om de bijdrage van H. pylori aan endogene nitrosering verder op te helderen. De resultaten laten zien dat, zowel in een neutraal als in een zuur milieu, door geen enkele van de geteste $H$. pylori stammen significante vorming van nitrosomorfoline is geïnduceerd. Als positieve controle is Neisseria cinerea getest en deze bacterie katalyseerde de nitroseringsreactie significant, hetgeen indiceert dat de testomstandigheden wel geschikt waren om nitrosaminevorming, gekatalyseerd door bacteriën, te bestuderen. Deze resultaten maken aannemelijk dat infectie met $H$. pylori geen factor is die vorming van kankerverwekkende nitrosamines in de maag veroorzaakt.

In Hoofdstuk 7 is de mogelijkheid van vorming van N-nitroso verbindingen buiten de maag bestudeerd. Hierbij is gebruik gemaakt van een in vitro model voor chronische ontsteking in de darm: een co-incubatie systeem met getransformeerde menselijke darmcellen (Caco-2 cellen) en geactiveerde menselijke polymorfonucleaire leukocyten (PMN). Dit model is gebruikt om de rol van geactiveerde PMN te bestuderen bij de vorming van kankerverwekkende $\mathrm{NOC}$, gemedieerd door productie van $\mathrm{NO}$, en om te onderzoeken of de gesynthetiseerde NOC in staat waren om in de Caco-cellen alkyl-DNA adducten te induceren. Aan de co-incubaties werden dimethylamine, morfoline en methylureum toegevoegd als nitroseerbare stoffen. Toevoegen van $5 \mathrm{mM}$ morfoline resulteerde in een kleine, maar significante, toename in de vorming van NMOR. Toevoegen van dimethylamine en methylureum resulteerde niet in de vorming van detecteerbare hoeveelheden NDMA en MNU. Tevens werden er geen detecteerbare hoeveelheden gealkyleerd DNA aangetroffen in de Caco-2 cellen. Deze resultaten suggereren dat menselijke PMN in staat zijn om kleine hoeveelheden kankerverwekkende NOC te synthetiseren in de darm tijdens een ontsteking, maar tevens dat deze NOC het DNA in de darmepitheelcellen niet beschadigen, mogelijkerwijs als gevolg van tijdige detoxificatie in het cytosol. In de in situ situatie zullen de niveaus van NOC, gesynthetiseerd door geactiveerde PMN, laag zijn en andere factoren dragen waarschijnlijk dan ook bij aan de 
associatie tussen chronische ontsteking en het risico van darmkanker, zoals deze epidemiologisch is vastgesteld.

Geconcludeerd kan worden dat de data die in dit proefschrift gepresenteerd zijn, aantonen dat nitraat inname ter hoogte van de huidige norm (de ADI) in combinatie met visconsumptie resulteert in een verhoging van de NDMA uitscheiding in urine van ongeveer $200 \%$, en dit reflecteert een verhoogde endogene vorming van NDMA. Echter, gebaseerd op deze resultaten kan slechts een zeer ruwe schatting gemaakt worden van de niveaus van NDMA die gevormd zijn in de maag. Supplementatie met vitamine $C$ en consumptie van gematigde hoeveelheden groene thee veroorzaakten een complete remming van de toename van NDMA uitscheiding, hetgeen indiceert dat chemopreventie van endogene vorming van kankerverwekkende NOC haalbaar is. Deze onderzoeken zijn uitgevoerd met gezonde vrijwilligers. Een contrasterende bevinding was dat patiënten met een verhoogd risico van NOC vorming in de maag een lagere NOC uitscheiding hadden in urine dan de vrijwilligers die gesupplementeerd waren met nitraat. Verder indiceren de in vitro data in Hoofdstuk 6 dat patiënten met een Helicobacter pylori infectie geen verhoogd risico hebben op endogene nitrosaminevorming in de maag.

De tweede doelstelling van dit proefschrift was om de mogelijke schadelijke effecten van endogeen gevormde kankerverwekkende NOC op DNA te evalueren. Hoewel in het algemeen de niveaus van NOC in de maag relatief hoog zullen zijn vergeleken met andere plaatsen in het lichaam, werden geen N7alkylguanosine adducten en K-ras mutaties gedetecteerd in DNA dat geïsoleerd was uit maagbiopten van patiënten met een hoge $\mathrm{pH}$ in de maag. Helaas was de detectielimiet van de methode om alkyl-DNA adducten te bepalen relatief hoog (1 adduct $/ 10^{6}$ nucleotiden) en gebaseerd op deze data kunnen genotoxische gevolgen van blootstelling aan NOC niet worden uitgesloten. Er zijn echter niveaus gerapporteerd van N7-methylguanine in lymfocyten van gezonde, nietrokende individuen van $13.5 / 10^{7}$ nucleotiden. Er kan gesuggereerd worden dat DNA adduct niveaus in een doelwitorgaan zoals de maag hoger zullen zijn dan in lymfocyten, en in dat geval zou de detectielimiet van onze methode acceptabel zijn.

Wat betreft de endogene nitrosering op andere plaatsen in het lichaam naast de maag, suggereert de in vitro studie met het co-incubatie systeem dat endogene vorming van kankerverwekkende nitrosamines ook kan optreden in de darm, en wel gemedieerd door geactiveerde inflammatoire cellen. Hoogstwaarschijnlijk worden hierbij lage tot matige niveaus van nitrosamines gevormd, die ook niet zullen leiden tot significante DNA adductvorming. 
In het algemeen kan er geen uiteindelijke conclusie getrokken worden over de relatie tussen hoge nitraatblootstelling en een mogelijk kankerrisico voor mensen, hoewel de studies die in dit proefschrift gepresenteerd worden veel informatie verschaffen over de endogene vorming van kankerverwekkende nitrosamines. Niettemin laat de studie met nitraat inname ter hoogte van de ADI zien dat er rekening gehouden moet worden met de endogene vorming van NOC bij het vaststellen van normen voor nitraat en nitriet. Dit houdt niet noodzakelijkerwijs in dat het absolute niveau van de normen veranderd moet worden, aangezien in deze studies een worstcase benadering gevolgd is, maar het indiceert wel dat met name de risicogroepen die in hoofdstuk 1 zijn gedefinieerd, voorzichtig moeten zijn met frequente consumptie van nitraatrijke groenten in combinatie met vis. Voor toekomstig onderzoek is het van belang om gevoeligere methoden te ontwikkelen voor de detectie van alkyl-DNA adducten, om meer inzicht te krijgen in de genotoxische gevolgen van endogene vorming van NOC. Verder zijn meer gegevens nodig over endogene vorming van NOC in de maag, en het maag-darm model beschreven in hoofdstuk 2 kan een belangrijke rol spelen in het behalen van dit doel. 


\section{Dankwoord}

Eindelijk is het dan zover: het proefschrift is klaar! Maar dat heb ik natuurlijk niet in m'n eentje gedaan. Veel mensen hebben in meer of mindere mate hun steentje bijgedragen tijdens de afgelopen jaren. Ik wil graag van deze gelegenheid gebruik maken om iedereen hiervoor te bedanken.

Allereerst mijn promotor Jos Kleinjans. Jos, met jouw scherpe, kritische denkwijze wist je me altijd weer op het goede spoor te zetten. Mijn manuscripten beoordeelde je razendsnel en je aanvullingen waren zeer waardevol.

Jan van Maanen, mijn co-promotor: Jan, je deur stond altijd voor me open en je was altijd behulpzaam als het nodig was (zelfs als er urinepotten moesten worden gespoeld!). Ook de afgelopen maanden heb ik nooit tevergeefs een beroep op je gedaan, bedankt daarvoor.

Leopold Engels, mijn co-promotor: De studie in hoofdstuk 5 was niet mogelijk geweest zonder al je moeite om geschikte patiënten te vinden en goed monstermateriaal te leveren. Ook de klinische input bij het schrijven van twee andere artikelen heb ik zeer gewaardeerd. Verder wil ik graag het verpleegkundig personeel bedanken van de afdeling gastroenterologie (Maaslandziekenhuis Sittard) voor hun fantastische hulp en ook de patiënten die belangenloos aan het onderzoek hebben deelgenomen.

Mayriam Stijns en Wendy Kölgen voor hun geweldige inzet tijdens het proefpersonenonderzoek (Hoofdstuk 3 en 4). Zonder jullie hulp had ik het niet gered. Ook de proefpersonen wil ik bedanken voor het wekenlang eten van vismaaltijden, drinken van groene thee en het verzamelen van alle urine.

Collega's van vakgroep GRAT voor alle hulp en gezelligheid. Dankzij jullie allemaal kijk ik met heel veel plezier terug op mijn AIO-tijd. Ik wil graag een aantal mensen met name noemen. Pauline Schilderman en Edwin Moonen, jullie zijn niet voor niets mijn paranimfen! Pauline, je was altijd mijn steun en toeverlaat. Edwin, bedankt voor al je hulp op het lab en alle metingen die je hebt verricht (mijn proefschrift zou anders erg leeg zijn!). Bikkel Marcel van Herwijnen, je had altijd wel goede tips voor de praktische uitvoering van de experimenten en was altijd bereid om mee te denken. Roel Schins, bedankt voor al je statistiek-adviezen en je geweldige limericks. Allan van Geel, jij hebt me in de beginperiode wegwijs gemaakt in de wereld van nitraat en nitriet, bedankt. Mijn kamergenoten wil ik graag bedanken voor alle gezelligheid, gesprekken en discussies: Soedjajadi Keman, Manon Jetten, Remko (met een K) Houba en Harald 
Moonen. Roger Godschalk voor de leuke studie-, stage- en AIO-tijd die we samen hebben doorgebracht. Daniëlle Pachen voor de metingen die je hebt gedaan en de gezellige tijd op het lab.

Een aantal mensen wil ik graag bedanken voor hun bijdrage aan het werk beschreven in hoofdstuk 6: Hans Kusters, Ernst Kuipers en Monique Gerrits (Vrije Universiteit Amsterdam). Monique, je hebt me de wondere wereld van de Helicobacter laten zien en je hebt me geweldig geholpen, zelfs op zondagen!

Daisy Jonkers, omdat je altijd bereid was om mijn vragen over Helicobacter te beantwoorden. Matt Hazen bedankt voor het werk dat je hebt gedaan.

Chantal Heijnen, Leo Baars en Guido Haenen, bedankt voor jullie bijdrage aan het NO werk (Hoofdstuk 7). Laila Henderson voor de hulp bij het uitvoeren van de experimenten.

Cyrille Krul en Susan Wijnhoven voor alle gezelligheid en de vele discussies. Cyrille, leuk dat we alsnog samen een studie hebben kunnen doen!

De leden van de beoordelingscommissie, bedankt voor de snelle beoordeling van het proefschrift.

Verder wil ik mijn collega's van Numico Research bedanken, en met name Hanno Cappon, voor hun begrip als ik weer een vrije dag moest opnemen om mijn proefschrift af te ronden. Sonja Zuijdgeest voor je goede lay-out tips.

Familie en vrienden voor hun belangstelling en steun.

Een bijzonder woord van dank voor mijn ouders, Marja en Theo: jullie hebben mij enorm gesteund en stonden altijd voor mij klaar.

En tenslotte John-Paul. Het leven van een AIO is niet altijd even gemakkelijk, maar daar kies je zelf voor. Maar als partner van een AIO heb je regelmatig heel wat te verduren! Jij hebt daar altijd begrip voor gehad en je was een enorme steun.

Allemaal bedankt!

Ingrid 


\section{Curriculum vitae}

Ingrid Theodora Maria Vermeer werd geboren op 29 november 1971 te Eindhoven. Na het behalen van het gymnasium beta diploma aan het Zwijsen College te Veghel in 1990, begon zij haar studie Gezondheidswetenschappen met als afstudeerrichting Biologische Gezondheidkunde aan de Universiteit Maastricht. Tijdens deze studie heeft zij tevens de certificaten 'Stralingshygiëne, deskundigheidsniveau 5b' en 'Proefdierkunde op grond van art. 9 van de Wet op de Dierproeven' behaald. De studie Gezondheidswetenschappen heeft zij in december 1995 afgesloten. Vanaf januari 1996 was zij werkzaam als assistent in opleiding bij de capaciteitsgroep Gezondheidsrisico Analyse en Toxicologie van de Universiteit Maastricht, alwaar het onderzoek beschreven in dit proefschrift werd uitgevoerd. Tijdens deze periode voltooide zij tevens de cursussen: 'Toxicologie 1: Principes en mechanismen', 'Toxicologie 2: Effecten en toepassingen' en 'Scheikunde 1: Van analyse tot synthese' aan de Open Universiteit te Heerlen. Vanaf maart 2000 is Ingrid werkzaam als toxicologe bij de afdeling voedingssupplementen van Numico Research BV te Wageningen. 


\section{List of publications}

\section{Articles}

- Godschalk RWL, Vermeer ITM, Kriek E, Floot B, Schilderman PAEL, Moonen EJC, Kleinjans JCS, Van Schooten FJ. Comparison of ${ }^{32} \mathrm{P}$-postlabeling and HPLC-FD analysis of DNA adducts in rats acutely exposed to benzo[a]pyrene. Chemico-Biological Interactions 104: 41-54 (1997).

- Vermeer ITM, Pachen DMFA, Dallinga JW, Kleinjans JCS, Van Maanen JMS Volatile $\mathrm{N}$-nitrosamine formation after intake of nitrate at the ADI level in combination with an amine-rich diet. Environmental Health Perspectives 106: 459-463 (1998).

- Vermeer ITM, Moonen EJC, Dallinga JW, Kleinjans JCS, Van Maanen JMS. Effect of ascorbic acid and green tea on endogenous formation of $\mathrm{N}$ nitrosodimethylamine and N-nitrosopiperidine in humans. Mutation Research 428: 353-361 (1999).

- Van Maanen JM, Albering HJ, De Kok TM, Van Breda SG, Curfs DM, Vermeer IT, Ambergen AW, Wolffenbuttel BH, Kleinjans JC, Reeser HM. Does the risk of childhood diabetes mellitus require revision of the guideline values for nitrate in drinking water? Environmental Health Perspectives 108: 457-461 (2000).

- Levallois P, Ayotte P, Van Maanen JMS, Desrosiers T, Gingras S, Dallinga JW, Vermeer ITM, Zee J, Poirier G. Excretion of volatile nitrosamines in a rural population in relation to food and drinking water consumption. Food and Chemical Toxicology, in press.

- Vermeer ITM, Engels LGJB, Pachen DMFA, Dallinga JW, Van Agen E, Kleinjans JCS, Van Maanen JMS. Intragastric volatile N-nitrosamines, nitrite, and $\mathrm{pH}$ during long-term treatment with omeprazole. Submitted for publication.

- Dallinga JW, Krul CAM, Tenfelde A, Moonen EJC, Vermeer ITM, Van Doorn D, Schothorst RC. Determination of N-nitrosodimethylamine in artificial gastric juice by gas chromatography-mass spectrometry and by gas chromatography-thermal energy analysis. Submitted for publication.

- Vermeer ITM, Henderson LY, Moonen EJC, Engels LGJB, Dallinga JW, Kleinjans JCS, Van Maanen JMS. Neutrophil-mediated formation of carcinogenic N-nitroso compounds in an in vitro model for intestinal inflammation. Submitted for publication. 
- Vermeer ITM, Gerrits MM, Moonen EJC, Engels LGJB, Dallinga JW, Kleinjans JCS, Van Maanen JMS, Kuipers EJ, Kusters JG. Evidence for the lack of Helicobacter pylori-mediated formation of carcinogenic $\mathrm{N}$-nitrosamines. Submitted for publication.

\section{Abstracts}

- Godschalk RWL, Vermeer ITM, Schilderman PAEL, Moonen EJC, Kleinjans JCS, Van Schooten FJ. The use of white blood cell DNA adducts in biologically effective dose monitoring of polycyclic aromatic hydrocarbons. $25^{\text {th }}$ Annual Meeting of the European Environmental Mutagen Society, June 13-18, Noordwijkerhout, The Netherlands. Mutation Research 360: 201 (1996).

- Vermeer ITM, Pachen DMF, Dallinga, JW, Kleinjans JCS, Van Maanen JMS. Nnitrosamine formation after intake of nitrate at the ADI level in combination with an amine-rich diet. $89^{\text {th }}$ Annual Meeting of the American Association for Cancer Research, March 28-April 1, New Orleans, USA (1998).

- Vermeer ITM, Engels LGJ, Pachen DMF, Dallinga JW, Kleinjans JCS, Van Maanen JMS. Intragastric N-nitrosodimethylamine formation in patients on long-term proton pump inhibitor therapy. $89^{\text {th }}$ Annual Meeting of the American Association for Cancer Research, March 28-April 1, New Orleans, USA (1998).

- Vermeer ITM, Moonen EJC, Dallinga JW, Van Maanen JMS, Kleinjans JCS. The effect of green tea consumption on formation of N-nitrosodimethylamine after intake of nitrate and fish. The $3^{\text {rd }}$ International Conference on Environmental Mutagens in Human Populations, November 29-December 4, Bangkok, Thailand (1998).

- Vermeer ITM, Engels LGJB, Pachen DMFA, Dallinga JW, Kleinjans JCS, Van Maanen JMS. Intragastric volatile $\mathrm{N}$-nitrosamines and related intragastric parameters during long-term treatment with omeprazole. Annual Meeting of the Dutch Societies for Gastroenterolgy and Hepatology, March 18-19, Veldhoven, The Netherlands (1999). Oral presentation. Published in: European Journal of Gastroenterology and Hepatology, December 1999.

- Vermeer ITM, Kleinjans JCS, Van Maanen JMS. Does formation of methylnitrosourea occur during inflammation? 29 ${ }^{\text {th }}$ Annual Meeting of the European Environmental Mutagen Society, July 4-9, Copenhagen, Denmark (1999). Published in: Pharmacology \& Toxicology 85 (suppl 1): 54 (1999).

- Vermeer ITM, Gerrits MM, Moonen EJC, Engels LGJB, Dallinga JW, Kleinjans JCS, Van Maanen JMS, Kusters JG, Kuipers EJ. Can H. pylori infection contribute to the intragastric formation of volatile N-nitrosamines? Gastroenterology (2000). 